\section{OAK RIDGE NATIONAL LABORATORY}

MARTIN MARIETTA
Treatment Requirements for Decontamination of ORNL Low-Level Liquid Waste

\author{
D. D. Lee \\ D. O. Campbell
}


This report has been reproduced directly from the best available copy.

Available to DOE and DOE contractors from the Office of Scientific and Technical Information, P.O. Box 62, Oak Ridge, TN 37831; prices available from (615) 576-8401, FTS 626-8401.

Available to the public from the National Technical Information Service, U.S. Department of Commerce, 5285 Port Royal Rd., Springfield, VA 22161.

This report was prepared as an account of work sponsored by an sgency of the United States Government. Neither the United States Government nor any agency thereof, nor any of their employees, makes any warranty, express or implied, or assumes any legal liability or responsibility for the accuracy, completeness, or usefuiness of any information, apparatus, product, or process disclosed, or represents that its use would not infringe privately owned rights. Reference herein to any specific commercial product, process, or service by trade name, trademark, manufacturer, or otherwise, does not necessarily constitute or imply its endorsement, recommendation, or favoring by the United States Government or any agency thereof. The views and opinions of authors expressed herein do not necessarily state or reflect those of the United States Government or any agency thereof. 


\title{
TREATMENT REQUIREMENTS FOR DECONTAMINATION OF ORNL LOW-LEVEL LIQUID WASTE
}

\author{
D. D. Lee \\ D. O. Campbell
}

Date of Issue: October 1991

Prepared for the

Office of Environmental Restoration and Waste Management

(EW 302002 1)

Prepared by the

OAK RIDGE NATIONAL IABORATORY

Oak Ridge, Tennessee 37831 managed by

MARTIN MARIETTA ENERGY SYSTEMS, INC.

for the

U.S. DEPARTMENT OF ENERGY under contract DE-AC05-84OR21400 


\section{CONTENTS}

LIST OF TABLES $\ldots \ldots \ldots \ldots \ldots \ldots \ldots \ldots \ldots \ldots \ldots \ldots \ldots \ldots$

ACRONYMS AND INITLALISMS $\ldots \ldots \ldots \ldots \ldots \ldots \ldots \ldots \ldots \ldots \ldots$

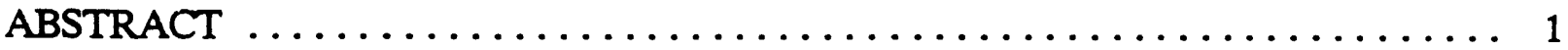

1. INTRODUCTION $\ldots \ldots \ldots \ldots \ldots \ldots \ldots \ldots \ldots \ldots \ldots \ldots \ldots \ldots \ldots \ldots$

2. SEPARATION REQUIREMENTS $\ldots \ldots \ldots \ldots \ldots \ldots \ldots \ldots \ldots \ldots \ldots$

3. DATA-BASE CALCULATIONS $\ldots \ldots \ldots \ldots \ldots \ldots \ldots \ldots \ldots \ldots \ldots$

3.1 LLLW AND RCRA TREATMENT/STORAGE/DISPOSAL

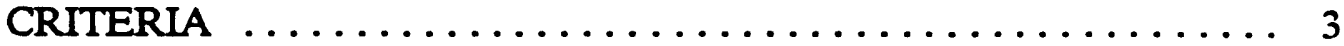

3.2 LLLW DISPOSAL UNCERTAINTIES $\ldots \ldots \ldots \ldots \ldots \ldots \ldots \ldots \ldots$

3.3 RESULTS OF DATA-BASE CALCULATIONS $\ldots \ldots \ldots \ldots \ldots \ldots \ldots$

3.3.1 Radiological Results ..................... 10

3.3.2 Chemical Composition Results ............... 11

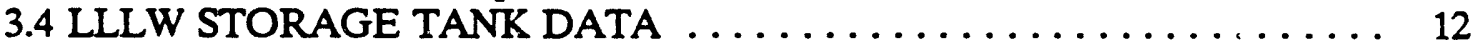

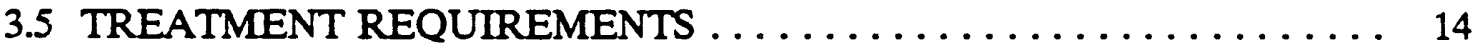

3.5.1 Treatment for Liquid Wastes . . . . . . . . . . . . . 16

3.5.2 Treatment Required for Solid LLW . . . . . . . . . . . . 22

3.5.3 Solidification of Supernate to a Fused Nitrate Salt Cake or

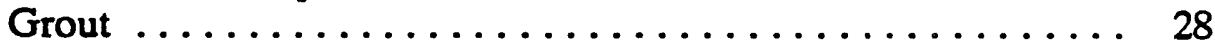

3.5.4 Solidification of Sludge to a Fused Nitrate Salt Cake or Grout . . . 30

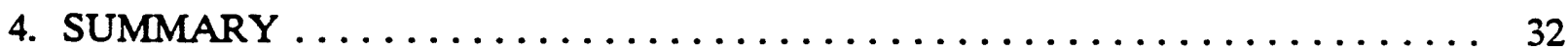

5. REFERENCES $\ldots \ldots \ldots \ldots \ldots \ldots \ldots \ldots \ldots \ldots \ldots \ldots \ldots \ldots \ldots \ldots \ldots$

APPENDIX A. DATA FOR LLLW TANKS $W-21$ and $W-23-W-31 \ldots \ldots \ldots$

APPENDIX B. DEFINITIONS AND COMPUTATIONAL METHODS FOR

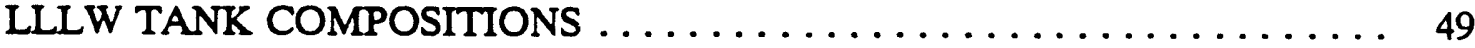




\section{LIST OF TABLES}

Table $\quad$ Page

1. Release and acceptance criteria for $L L L W \ldots \ldots \ldots \ldots \ldots \ldots \ldots \ldots$

2. NRC, LLWDDD, and NUS waste classification limits for solid LLW . . . . . 6

3. Maximum, minimum, and average radiochemical concentrations in the LLLW tanks 8

4. Maximum, minimum, and average chemical concentrations in the LLLW tanks ... 9

5. Summation of constituents in the MVSTs $\ldots \ldots \ldots \ldots \ldots \ldots \ldots \ldots \ldots \ldots$

6. Required activity reduction factors to meet various standards $\ldots \ldots \ldots \ldots \ldots 14$

7. ARFs to treat supernate to DOE 5400.5 DCG standards and to the WAC for the

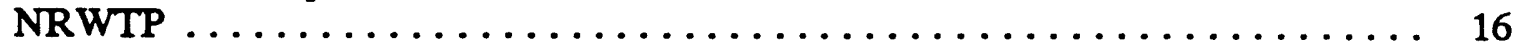

8. ARFs to treat supernate to DOE 5400.5 DCG drinking water standards . . . . . 18

9. Supernate ARFs for 10 CFR 20 standards for release to White Oak Creek .... . 19

10. ARFs to treat supernate to WAC for the PWTP $\ldots \ldots \ldots \ldots \ldots \ldots$

11. ARFs to treat supernate to the NRWTP WAC for the nonradioactive components 20

12. Supernate DFs to reach the NRWTP WAC with dilution for the radioactive

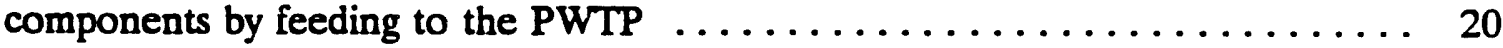

13. Supernate DFs to reach NRC Class A, B, and C standards for solid waste forms with a $1.3: 1$ volume increase $\ldots \ldots \ldots \ldots \ldots \ldots \ldots \ldots \ldots \ldots \ldots \ldots$

14. Supernate DFs for LLWDDD Class L-I, L-II, and L-III for concrete waste forms

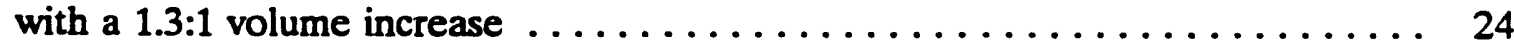

15. Supernate DFs for NUS Class $L-1$ and L-2 limits for concrete waste forms . . . 25

16. Radiation content when untreated supernate is solidified in concrete $\ldots \ldots \ldots 27$

17. Radiation content of drums when untreated supernate is solidified in concrete . . 27

18. MVST supernates processed to sodium nitrate salt cake . . . . . . . . . . . 29

19. MVST sludges processed to sodium nitrate salt cake or cement grout $\ldots \ldots \ldots 31$

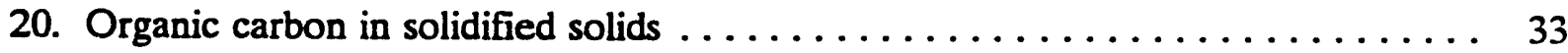

A. Analytical and radiological data for LLLW tank $W-21 \ldots \ldots \ldots \ldots \ldots \ldots$

A.2. Analytical and radiological data for LLLW tank $W-23 \ldots \ldots \ldots \ldots . \ldots . \ldots . . \ldots 39$

A.3. Analytical and radiological data for LLLW tank W-24 . . . . . . . . . . . . 40

A.4. Analytical and radiological data for LLLW tank W-25 . . . . . . . . . . . 41

A.5. Analytical and radiological data for LLLW tank $W-26 \ldots \ldots \ldots \ldots \ldots \ldots$

A6. Analytical and radiological data for LLLW tank W-27 . . . . . . . . . . 43

A.7. Analytical and radiological data for LLLW tank W-28 . . . . . . . . . . . . 44

A.8. Analytical and radiological data for LLLW tank W-29 . . . . . . . . . . . . 4 5

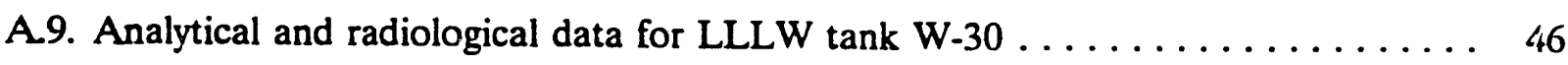

A.10. Analytical and radiological data for LLLW tank $W-31 \ldots \ldots \ldots \ldots \ldots$

A.11. Summation of constituents in all LLLW tanks . . . . . . . . . . . . 48 


\section{ACRONYMS AND INITIALISMS}

\begin{tabular}{|c|c|}
\hline ALARA & As Low As Reasonably Achievable \\
\hline ARF & Activity Reduction Factor \\
\hline CER & Code of Federal Regulations \\
\hline DF & Decontamination Factor $\left(C_{0} / C\right)$ \\
\hline DCG & Derived Concentration Guide \\
\hline DOE & U.S. Department of Energy \\
\hline DOT & U.S. Department of Transportation \\
\hline EIS & Environmental Impact Statement \\
\hline EPA & U.S. Environmental Protection Agency \\
\hline EPTC & Extraction Procedure Toxicity Characteristic \\
\hline FCN & Potassium or sodium—cobalt or nickel ferrocyanide ion exchanger \\
\hline IX & Ion Exchange (processes) \\
\hline LDR & Land Disposal Restrictions \\
\hline LLLW & Low-Level (radioactive) Liquid Waste \\
\hline LLW & Low-Level (radioactive) Waste \\
\hline LLWDDD & Low-Level Waste Disposal Development and Demonstration (Program) \\
\hline MVST & Melton Valley Storage Tank \\
\hline NPDES & National Pollutant Discharge Elimination System \\
\hline NRC & Nuclear Regulatory Commission \\
\hline NRWTP & Nonradiological Waste Treatment Plant \\
\hline ORNL & Oak Ridge National Laboratory \\
\hline PWTP & Process Waste Treatment Plant \\
\hline RCRA & Resource Conservation and Recovery Act \\
\hline RH & Remote Handled \\
\hline TCLP & Toxicity Characteristic Leaching Procedure \\
\hline TDHE & Tennessee Department of Health and Environment \\
\hline TOC & Total Organic Carbon \\
\hline TRU & Transuranic \\
\hline TSD & Treatment/Storage/Disposal \\
\hline WAC & Waste Acceptance Criteria \\
\hline WIPP & Waste Isolation Pilot Plant \\
\hline WOC & White Oak Creek \\
\hline
\end{tabular}




\title{
TREATMENT REQUIREMENTS FOR DECONTAMINATION OF ORNL LOW-LEVEL LIQUID WASTE
}

\author{
D. D. Lee \\ D. O. Campbell
}

\begin{abstract}
AESTRACT
Experimental studies have been made to provide data for the development of improved processes for decontaminating low-level liquid wastes (LLLWs) that exist and continue to be generated at Oak Ridge National Laboratory. The concept underlying this work is that there is a net benefit if the major radionuclides $\left({ }^{137} \mathrm{Cs}\right.$, ${ }^{134} \mathrm{Cs}$, ${ }^{90} \mathrm{Sr}$, and actinides) can be separated into small volumes, thereby reducing the activity of the bulk of the waste so that it can be disposed of or managed at a lower total cost.

Data-base calculations on the LLLW supernate and sludges contained in the active Melton Valley Storage Tanks and evaporator storage and service tanks are essential in order to define and determine the extent of the problem. These calculations indicate to what extent alpha- and beta-gammaemitting radionuclides must be removed and/or treated before final disposition of the waste can be made. They also show that many of the inorganic constituents (e.g., regulated metals and nitrate) and minor radionuclides such as ${ }^{14} \mathrm{C}$ and actinides (in terms of quantity present) must be removed before the LLLW can be disposed of as either liquid to the environment or solidified and disposed of as solid NUS Class L-I or L-II LLW.
\end{abstract}

\section{INTRODUCTION}

Low-level liquid waste (LLLW) at Oak Ridge National Laboratory (ORNL) consists of various concentrates from evaporators and from the elution of ion-exchange columns, as well as solutions from laboratories and chemical processing operations for radioisotope and actinide element production. The volume is small, 10 to $20 \mathrm{~m}^{3} / \mathrm{year}$, but has a very high concentration of dissolved solids. Typically, it contains about $5 \underline{M}$ sodium nitrate, excess $\mathrm{NaOH}$, significant concentrations of potassium, calcium, and magnesium, and small amounts of several other elements, including some Resource Conservation and 
Recovery Act (RCRA) metals. The hazardous components in the wastes are dominated by actinides, ${ }^{137} \mathrm{Cs} /{ }^{134} \mathrm{Cs},{ }^{60} \mathrm{Co},{ }^{14} \mathrm{C}$, and ${ }^{90} \mathrm{Sr}$. In stored, highly basic LLLW, the actinides are generally insoluble, and most have precipitated out so that the supernate is generally a nontransuranic waste. However, traces of some actinides remain at measurable levels.

The concept underlying the present work is to treat the LLLW so that it can be disposed of in an appropriate manner. In many cases, the disposal option would require decontamination of the LLLW so that the main bulk of the waste can be managed as a less hazardous material which has an approved disposal mechanism. The small volume of highactivity concentrate separated from the bulk can be handled with great care, possibly also being disposed of or stored until an acceptable disposal method has been established. To implement this strategy, the removal of cesium, cobalt, and strontium from very large amounts of sodium and potassium, and smaller amounts of other elements, including alkaline earths and transition metals, may be necessary. In addition, the trace quantities of actinides remaining in some of the supernates may need to be removed to meet some of the storage or disposal requirements. The ${ }^{14} \mathrm{C}$ present in the supernate, either as inorganic carbonate or organic compounds, may also require removal to meet some requirements.

\section{SEPARATION REQUIREMENTS}

In chemical separations processes for the ivlation of cesium, the primary interferences are usually other alkali metals, especially the heavier ones. In the case of the LLLW supernate, sodium is present in very high concentrations, 3 to $4 \mathrm{M}$, and the potassium concentration is also significant, 0.25 to $2.0 \underline{\mathrm{M}}$, with an average of $0.5 \underline{\mathrm{M}}$. Therefore, depending on the particular process, sodium and/or potassium tend to interfere with cesium removal. In a similar way, alkaline-earth elements interfere with strontium removal. Calcium and magnesium are present in high concentrations in the LLLW supernate. In some cases, high alkali-metal concentrations also interfere with strontium decontamination steps.

In order to determine which separation methods may be required for decontamination, it was important to know the contents of each tank, both chemically and radiologically, and the quantity of each constituent present. Until this information is known and has been compared with the current and proposed Treatment/Storage/Disposal (TSD) requirements, processes for efficient decontamination cannot be designed with any certainty. 


\section{DATA-BASE CALCULATIONS}

\subsection{LLLW AND RCRA TREATMENT/STORAGE/DISPOSAL CRITERIA}

Data have been collected, collated, and analyzed for the supernate and sludge contained in the MVSTs and in tanks W-21 and W-23, the evaporator storage tanks. The analytical data, obtained from samples acquired during a 1989 sampling campaign, have been reviewed over the past several months. ${ }^{1,2}$ Earlier analyses of tanks W-29 and W-30 sludge were used because sludge sampling of these two tanks could not be done in the configuration for the solidification campaign. ${ }^{3}$ The results were then compared with the criteria for the release and disposal of $L L L W$ and solid radioactive waste via various disposal options that are given in Tables 1 and 2.47 The waste acceptance criteria (WAC) for the Process Waste Treatment Plant (PWTP) and the Nonradiological Waste Treatment Plant (NRWTP) are included. ${ }^{8}$ The NRWTP discharge limits are currently based on the I'Tational Pollutant Discharge Elimination System (NPDES) permit and are subject to change as new permits are negotiated with the TDHE. They are not included at this time. Also included in these criteria tables is a listing of the RCRA limits, primary and secondary drinking-water limits, and groundwater/water quality limits for components found in either the supernate or the sludge. ${ }^{9.15}$ The largest nonradioactive contaminant in the supernate is nitrate, when compared with the various water quality standards. A maximum of $10 \mathrm{ppm}$ nitrate, as nitrogen, is allowed for drinking water and in the WAC for the PWTP and NRWTP. Since the supernate is 3 to $6 \underline{M}$ in nitrate, nitrate removal is required before any of this material can be released.

An additional complication for supernate and sludge solidification and disposal is that the solids may be considered mixed waste according to the definition: ${ }^{16}$

... waste that satisfies the definition of low-level radioactive waste in the Low-Level Radioactive Waste Policy Amendments Act of 1985 and contains hazardous waste that either (1) is listed as a hazardous waste in Subpart D of 40 CFR 261 or (2) causes the LLW to exhibit any of the hazardous waste characteristics identified in Subpart C of 40 CFR 261.

The supernates contain radioactive species, and those with $\mathrm{pH}>12.5$ exhibit the hazardous waste characteristic of corrosivity (40 CFR 261, Subpart C). Several of the RCRA metals are also contained in the supernate in amounts that may be in excess of those allowed, although analyses are at the limits of detection in the high-sodium, highpotassium matrix. The sludges contain significantly more of the RCRA metals and may 
Table 1. Release and acceptance criteria for LLLW

\section{A. Radioactive Materials}

\begin{tabular}{|c|c|c|c|c|c|c|c|c|}
\hline Component & $\begin{array}{l}\text { PWTP WAC } \\
\left(n C_{1} / L\right)\end{array}$ & $\begin{array}{l}\text { DOE } 5400.5 \\
(\text { RRWTP WAC } \\
(n C i / L)\end{array}$ & $\begin{array}{l}10 \text { CFR 20 } \\
\text { Iab.II Col } 2 \\
\text { Plant } \\
\text { boumdary } \\
\text { (nCI/L) }\end{array}$ & $\begin{array}{l}0 \text { App. B } \\
\text { Iab. I. Col, } 2 \\
\text { To a mixed } \\
\text { somer strean } \\
(n C l / L)\end{array}$ & $\begin{array}{l}10 \mathrm{CFR} 20, \\
\text { App. C } \\
(\mathrm{MC} / \mathrm{d})\end{array}$ & $\begin{array}{l}4 \pi \text { DOE } 5400.5 \\
\text { for drinking } \\
\text { water systems } \\
\text { (nCl/L) }\end{array}$ & $\begin{array}{l}\text { Specific } \\
\text { ectivity } \\
(\mathrm{C}) / \mathrm{B})\end{array}$ & $\begin{array}{l}A_{2}^{b} \\
\text { (C1) }\end{array}$ \\
\hline B-3 & 2000 & 2000 & 3000 & 100,000 & 1000 & 80.00 & $9.7 E+03$ & 1000 \\
\hline$c-14$ & 70 & 70 & 800 & 20,000 & & 2.80 & $4.6 E+00$ & 60 \\
\hline Co-60 & 5.0 & 5.0 & so & 1.000 & 1 & 0.20 & $1.1 E+03$ & 7 \\
\hline$N_{1}-63$ & 300 & 300 & 30 & 800 & 10 & 12.00 & $4.62+01$ & 100 \\
\hline$S_{r}-90$ & 270 & 1.0 & 0.3 & 10 & 0.1 & 0.04 & $1.5 E+02$ & 0.4 \\
\hline$z_{I}-93$ & 90 & 80 & 800 & 20,000 & 10 & 3.60 & $3.5 E-03$ & 200 \\
\hline $\mathrm{Nb}-95$ & 40 & 40 & 100 & 3,000 & 10 & 1.60 & $3.9 E+04$ & 20 \\
\hline$z=-95$ & 40 & 40 & 60 & 2,000 & 10 & 1.60 & $2.1 E+04$ & 20 \\
\hline Tc- 98 & 100 & 100 & 300 & 10,000 & 10 & 4.00 & 1. $7 E-02$ & 25 \\
\hline Ru-106 & 6.0 & 6.0 & 10 & 300 & 1 & 0.24 & 3. $4 E+03$ & 7 \\
\hline$I-129$ & 0.5 & 0.5 & 0.06 & 10 & 0.1 & 0.02 & $1.6 \mathrm{E}-04$ & 2 \\
\hline$I-131$ & 3.0 & 3.0 & 0.30 & 60 & 1 & 0.12 & $1.2 E+05$ & 10 \\
\hline $\mathrm{Cs}-134$ & 2.0 & ن. & 8 & 300 & 1 & 0.08 & $1.2 E+03$ & 10 \\
\hline$C s-137$ & 10.8 & 3.0 & 20 & 400 & 10 & 0.12 & 9. $8 \mathrm{E}+01$ & 10 \\
\hline $\mathrm{Ce}-144$ & 7.0 & 7.0 & 70 & 200 & 10 & 0.28 & $3.2 E+03$ & 7 \\
\hline Som-151 & 400. & 400 & 400 & 40,000 & 10 & 16.00 & $2.6 E+01$ & 90 \\
\hline$E u-152$ & 20. & 20.0 & . 80 & 2,000 & 1 & 0.80 & $1.9 E+02$ & 10 \\
\hline$E u-154$ & 20. & 20.0 & 20 & 600 & 1 & 0.80 & 1. $5 E+02$ & 5 \\
\hline$E u-155$ & 100 & 100.0 & 200 & 6,000 & 10 & 4.00 & $1.4 E+03$ & 60 \\
\hline Th-natural & 0.05 & 0.05 & & & & 0.0004 & $2.2 E-07$ & No Limit \\
\hline $\mathrm{Th}-230$ & 0.30 & 0.3 & 2 & so & 100 & 0.012 & $1.9 E-02$ & 0.003 \\
\hline Th-232 & 0.05 & 0.05 & 2 & so & 100 & 0.002 & 1. 1E-07 & No limit \\
\hline $\mathrm{Pa}-231$ & 0.01 & 0.01 & 0.8 & 30 & & 0.0004 & $4.5 E-02$ & 0.002 \\
\hline$U-232$ & 0.10 & 0.10 & 30 & 800 & & 0.004 & 2. $1 E+01$ & 0.03 \\
\hline$U-233$ & 0.50 & 0.50 & 30 & 900 & 0.01 & 0.02 & $9.5 E-03$ & 0.1 \\
\hline$U-234$ & 0.60 & 0.60 & 30 & 800 & 0.01 & 0.024 & 6 गЕ 03 & 0.1 \\
\hline$U-235$ & 0.60 & 0.60 & 30 & 800 & 0.01 & 0.024 & 2.1E-06 & 0.2 \\
\hline$U-238$ & 0.50 & 0.50 & 40 & 1,000 & 100 & 0.02 & $3.3 E-07$ & No limit \\
\hline U-natural & 0.60 & 0.60 & & & & 0.024 & $7.18-07$ & No $11 \mathrm{mit}$ \\
\hline Np-237 & 0.03 & 0.03 & 3 & 90 & & 0.0012 & $6.9 E-04$ & 0.005 \\
\hline Pu-238 & 3.00 & 3.00 & 5 & 100 & & 0.12 & $1.7 E+01$ & 0.003 \\
\hline Pu-239 & 2.00 & 2.00 & 5 & 100 & 0.01 & 0.08 & $6.2 E-02$ & 0.002 \\
\hline$P u-240$ & 2.00 & 2.00 & 5 & 100 & & 0.08 & $2.3 E-01$ & 0.002 \\
\hline Pu-241 & 2.00 & 2.00 & 200 & 7000 & & 0.08 & $1.1 \mathrm{E}+02$ & 0.1 \\
\hline$P u-242$ & 0.03 & 0.03 & 5 & 100 & & 0.0012 & $3.9 E-03$ & 0.003 \\
\hline$A m-241$ & 0.03 & 0.03 & 4 & 100 & 0.01 & 0.0012 & $3.2 E+00$ & 0.008 \\
\hline Am-243 & 0.03 & 0.03 & 4 & 100 & & 0.0012 & $1.9 \mathrm{E}-01$ & 0.008 \\
\hline $\mathrm{Cm}_{\mathrm{m}}-243$ & 0.05 & 0.05 & 5 & 100 & & 0.002 & 4. $2 E+01$ & 0.009 \\
\hline $\mathrm{Cm}-244$ & 0.06 & 0.06 & 7 & 200 & & 0.0024 & $8.2 E+01$ & 0.01 \\
\hline Gross alpha & 0.27 & 0.015 & 0.03 & 0.40 & 0.01 & 0.0006 & & 0.002 \\
\hline
\end{tabular}

awAC = Waste Acceptance Criteria.

$b_{\mathrm{A}_{2}}$ is the maximum activity of radioactive material permitted in a type A package according to 10 CFR 71 for the packasing, shipment, and transportation of radioactive material (see ref. 17). 
Table 1 (continued)

B. Nonradioactive Materials

\begin{tabular}{|c|c|c|c|c|c|c|}
\hline Component & $\begin{array}{c}\text { PWTP WACa } \\
\text { (ms/L) }\end{array}$ & $\begin{array}{c}\text { IRWTP KAC* } \\
\text { (ms/L) }\end{array}$ & $\begin{array}{c}40 \mathrm{CFR} 261 \\
(\mathrm{mg} / \mathrm{L}) \\
\end{array}$ & $\begin{array}{l}40 \text { CFR 265, App. III } \\
\text { Drinking Water } \\
(m s / L)\end{array}$ & $\begin{array}{l}40 \text { EFR } 141.11 \\
\text { Primary D.W. } \\
\text { (ms/L) }\end{array}$ & $\begin{array}{r}10 \text { CFR } 143.3 \\
\text { Secondary D.W. } \\
(\mathrm{mg} / \mathrm{L})\end{array}$ \\
\hline Chloride & & & & & & 250 \\
\hline Cyanide & & 0.09 & & & & \\
\hline $\mathrm{SO}_{4}$ & 0.0 & 940.00 & & & & 250 \\
\hline $\mathrm{PO}_{4}$ & 5.0 & --- & & & & \\
\hline $\mathrm{NO}_{3}=\mathrm{N}$ & 10.0 & 8.60 & & 10. & 10.0 & \\
\hline Antimony & & 42.00 & & & & \\
\hline Arsenic & & 5.25 & 5.0 & 0.05 & 0.05 & \\
\hline Baxium & & 6.00 & 100.0 & 1.0 & 1.0 & \\
\hline Beryllium & & 0.009 & & & & \\
\hline Cadmium & 0.7 & 1.90 & 1.0 & 0.01 & 0.01 & \\
\hline Chromium & 3.0 & 10.00 & 5.0 & 0.05 & 0.05 & \\
\hline Copper & 3.5 & 18.50 & & & & 1.0 \\
\hline Iron & & 105.00 & & & & 0.3 \\
\hline Lead & 0.7 & 5.25 & 5.0 & 0.05 & 0.05 & \\
\hline Manganeso & & & & - & & 0.05 \\
\hline Mercury & & 0.009 & 0.2 & 0.002 & 0.002 & \\
\hline Nickel & 4.0 & 38.00 & 30.0 & & & \\
\hline Solonium & & 3.75 & 1.0 & 0.01 & 0.02 & \\
\hline Silver & 0.5 & 0.26 & 5.0 & 0.05 & 0.05 & \\
\hline Thellium & & & 0.9 & & & \\
\hline Zinc & 2.7 & 38.00 & & & & 5.0 \\
\hline IOC & & 37,50 & & & & \\
\hline
\end{tabular}

These are maximem limits that can be accepted into the facilities. Thoy apply to waste volumes under $300 \mathrm{gal} / \mathrm{d}$. Larger waste volumes must recelve speciel ORNL Waxte Managenent approval before being discharged to the RRWTP. 
Table 2 NRC, LLWDDD, and NUS waste classification limits for solid LLW

\begin{tabular}{|c|c|c|c|c|c|c|c|c|c|}
\hline Component & $\begin{array}{l}\text { Conversion } \\
\text { Lactor } \\
\text { (mol/L oquivalont } \\
\text { to } \mu \mathrm{cl} / \mathrm{m}^{3} \text { ) } \\
\end{array}$ & $\begin{array}{l}\text { LLWDDD } \\
L-I \\
\left(\mu C_{1} / m^{3}\right)\end{array}$ & $\begin{array}{l}\text { LLWDDDa } \\
L-I I \\
\left(\mu C_{1} / m^{3}\right)\end{array}$ & $\begin{array}{l}\text { LLWDDDa } \\
L-I I I \\
\left(\mu C \pm / m^{3}\right)\end{array}$ & $\begin{array}{l}\text { Nusb } \\
L-I \\
\left(\mu \mathrm{Ci} i / m^{3}\right)\end{array}$ & $\begin{array}{l}\text { Nus }^{b} \\
I-I I^{c} \\
\left(\mu c_{1} / m^{3}\right)\end{array}$ & $\begin{array}{l}\operatorname{RRCA} \\
\left(\mu C_{1} / m^{3}\right.\end{array}$ & $\begin{array}{l}\text { IRC B } \\
2\left(\mu C_{1} / m^{3}\right)\end{array}$ & $\begin{array}{l}\text { NRC C } \\
\left(\mu C 1 / m^{3}\right)\end{array}$ \\
\hline $\mathrm{E}-3$ & & $1.88 \mathrm{E} 05$ & 7.29E11 & & $4.30 \mathrm{E} 02^{d}$ & - & 4.0E7 & & \\
\hline Be-10 & & $3.63 \mathrm{E03}$ & 5.82503 & $3.45 E 05$ & $5.18 \mathrm{E} 03$ & $\bullet$ & & & \\
\hline$c-14$ & $6.70 \mathrm{E}-7$ & 4.32E04 & $1.08 \mathrm{E} 05$ & $5.40 E 05$ & $1.07 E 00$ & $2.01 \mathrm{E02}$ & 8.0ES & $8.0 \mathrm{E5}$ & 8.0E6 \\
\hline $\mathrm{Co}-60$ & $2.25 E-10$ & 2.49804 & $3.82 E 18$ & & $3.24 E 07$ & $\bullet$ & $7.0 \mathrm{~EB}$ & & \\
\hline$N_{i}-63$ & & 4.71504 & 4.27505 & & $5.60 \mathrm{EO4}$ & 2.83E04 & $3.5 E 6$ & $7.0 \mathrm{E7}$ & $7.0 \mathrm{~EB}$ \\
\hline $5 r-90$ & $6.84 E-11$ & $9.24 \mathrm{EOZ}$ & $6.24 E 0 S$ & & 8.80z02 & $2.28 \mathrm{E} 06$ & 4.054 & $1.5 E B$ & 7.0E9 \\
\hline $2 x-93$ & & $1.95 \mathrm{E} 05$ & $1.94 E 05$ & 5.99E05 & $2.50 \mathrm{E} 02$ & 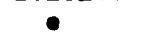 & & & \\
\hline Tc-98 & & 8.02502 & $1.38 E 03$ & 5.00E05 & 8.38E00 & $5.53 \mathrm{E} 00$ & 3.055 & & 3.056 \\
\hline$C d-113 m$ & & $2.65 \mathrm{E} 03$ & 1.49509 & & $1.68 \mathrm{E} 04$ & $\bullet$ & & & \\
\hline Sn-121m & & $1.81 \times 06$ & $3.01 E 07$ & & 1.36103 & - & & & \\
\hline$I-128$ & & & & & & $1.06 \mathbf{E 0 0}$ & 8.0E3 & & 8.084 \\
\hline$C 8-137$ & $2.18 \mathrm{E}-11$ & 3.07502 & $1.54 E 05$ & & 7.22502 & $1.26 \mathrm{E} 08$ & $1.0 \mathrm{E} 6$ & 4.4E7 & 4.689 \\
\hline$S m-151$ & & $3.83 E 06$ & $2.53 E 06$ & & $1.34 \mathrm{EO}$ & 1. 35208 & & & \\
\hline Eu-152 & $1.81 E-13$ & $6.39 E 02$ & $3.54 E 08$ & & $1.04 \mathrm{EOH}$ & $\bullet$ & & & \\
\hline Eu-154 & $9.87 E-11$ & 2.28503 & $1.13 E 12$ & & 1.82505 & $\bullet$ & & & \\
\hline Eu-155 & $1.37 E-8$ & 2.98E06 & 7.14E21 & & $9.74 E 08$ & - & • & & \\
\hline $\mathrm{Th}-232$ & $6.88 E-4$ & $1.78 \mathrm{E} 01$ & 2.72501 & $5.08 \mathrm{E} 02$ & $4.18 E-01$ & $\bullet$ & $5.0 \mathrm{E} 3^{f}$ & & $5.0 E_{4}$ \\
\hline$v-233$ & $3.58 \mathrm{E}-8$ & $7.92 \Sigma 01$ & 4.36803 & 8.70503 & $5.20 \mathrm{E01}$ & 2.36ะ01 & 5.053 & & $5.0 E_{4}$ \\
\hline$U-235$ & $1.57 \mathrm{E}-4$ & $7.77 E 01$ & 8.34E02 & $9.46 \mathrm{E} 03$ & 8.56500 & 2.53501 & $5.0 E_{3}$ & & $5.0 E_{4}$ \\
\hline$U-238$ & $4.715-10$ & 6.57E01 & $2.54 E 03$ & $9.61 \mathrm{E03}$ & 3.05501 & 2.75501 & $5.0 E 3$ & & $5.0 E_{4}$ \\
\hline Np-237 & $8.86 E-8$ & 1. $45 E 01$ & $2.86 \mathrm{EO} 1$ & $5.21 E 02$ & $1.63 E-02$ & $2.86 \mathrm{E01}$ & $5.0 \mathrm{E3}$ & & $5.0 E_{4}$ \\
\hline Pu-238 & $4.72 E-10$ & 1.91503 & 4.91803 & & $2.08 \mathrm{E02}$ & 1.49801 & 5.083 & & $5.0 E_{4}$ \\
\hline Pu-239 & $7.70 \mathrm{E}-8$ & 1.14E03 & $3.99 E 02$ & $6.05 E 02$ & $4.892-01$ & $2.95 z-01$ & $5.0 \mathrm{E3}$ & & $5.0 E_{4}$ \\
\hline Pu-241 & $1.62 E-8$ & & & & 8.09E02 & $1.45 E 05$ & $1.8 E 5$ & & $1.8 E 6$ \\
\hline$P u-242$ & $4.55 \mathrm{E}-5$ & & & & 5.20800 & 2.222507 & 5.053 & & $5.0 E_{4}$ \\
\hline$A m-241$ & $1.26 E-8$ & 9.74E02 & $6.37 E 02$ & $9.58 \mathrm{EO} 2$ & 1.0ge01 & $2.15 E 03$ & $5.0 \mathrm{E3}$ & & $5.0 E_{4}$ \\
\hline$A m-243$ & $7.00 \mathrm{E}-8$ & $3.23 E 02$ & $2.73 \mathrm{EO2}$ & 6.03E02 & $1.03 \mathrm{E} \cap 0$ & 1.81801 & $5.0 E^{3}$ & & $5.0 E_{4}$ \\
\hline$C_{m}-242$ & & & & & & & $1.0 E_{6}$ & & $1.0 \mathrm{E} 7$ \\
\hline$C_{D}-243$ & $1.18 \mathrm{E}-10$ & & & & $1.66 \mathrm{E} 03$ & $1.03 E 06$ & $5.0 \mathrm{E} 3$ & & $5.0 E_{4}$ \\
\hline $\mathrm{Cm}-244$ & $6.80 E-11$ & $1.36 E 04$ & 7.35E07 & & $1.02 E 03$ & 2.14EO2 & $5.0 E 3$ & & $5.0 E 4$ \\
\hline Gross alph & & & & & & & $5,0 E_{3}$ & & $5.0 E_{4}$ \\
\hline
\end{tabular}

ILLWDD Class L-I, L-II, and L-III concontrations.

broposed NUS Class L-I and L-II concentrations, based on limiting intruder scenarios (May 1990 data).

CWastes exceeding the L-II limits are classed as L-IV wastes.

druS limits that are more strict then the previous LLWDDD limits are given in bold.

- Allowable inventory is greater than $1 \times 10^{12}$ (>IE12) Ci.

fAssumes a donsity of $28 / \mathrm{cm}^{3}$ to convert from $\mathrm{nCi} / \mathrm{s}$ to $\mu \mathrm{Cl} / \mathrm{m}^{3}$ zor all alpha emitters for solidified grout. 
also contain some of the Toxicity Characteristic Leaching Procedure (TCLP) organics, in addition to the bulk of the actinides in the tanks. Summaries of the maximum, minimum, and average concentrations of radionuclides and chemical compositions for both supernate and sludge are shown in Table 3 and 4, respectively. ${ }^{1-3}$

Table 2 lists the proposed LLWDDD LLW limits for Class I, II, and III. ${ }^{18}$ LLWDDD values were originally developed as conservative estimates of the projected WAC for on-site disposal. Currently, only on-site disposal or disposal at WIPP is approved for ORNL solid LLW. Updated limits have been proposed by NUS (May 1990) for classes L-I ard L-II, based on studies using pathway analysis for homesteader (10 mrem), drinking water (4 mrem), and generai public (10-mrem air pathway) to define limits for the Oak Ridge Reservation site Environmental Impact Statement (EIS). The NRC limits, although not currently applicable to the Laboratory LLW, are given for comparison with requirements of the nuclear power industry. The NRC categorizes LLW as Class A, B, C, or greater than $\mathrm{C}$, depending on the nuclides present and their concentrations. If ${ }^{14} \mathrm{C}$, ${ }^{99} \mathrm{Tc}$, ${ }^{129} \mathrm{I},{ }^{241} \mathrm{Pu},{ }^{242} \mathrm{Cm}$, or gross alpha composed of isotopes with half-lives greater than 5 years are present at greater-than-Class- $A$ limits in Table 2 but less-than-Class-C limits, the waste is Class $C$. If they are present at less-than-Class-A limits, the waste is classified by the short-lived nuclides ${ }^{137} \mathrm{Cs},{ }^{90} \mathrm{Sr},{ }^{3} \mathrm{H},{ }^{60} \mathrm{Co}$, or ${ }^{63} \mathrm{Ni}$ that may be present. The Class $\mathrm{A}$ and $\mathrm{C}$ limits for alpha materials are taken from 10 CFR 61 , which gives the units as $\mathrm{nCi} / \mathrm{g}$. These limits were converted to $\mu \mathrm{Ci} / \mathrm{m}^{3}$ for use in determining the classification of a solid waste form by assuming a density of $2 \mathrm{~g} / \mathrm{cm}^{3}$. Therefore, a limit of $10 \mathrm{nCi} / \mathrm{g}$ becomes $5000 \mu \mathrm{Ci} / \mathrm{m}^{3}$. If more than ore of these isotopes is present, the sum of the fractions of nuclides must be less than 1 to fall into that classification.

\section{LLLW DISPCSAL UNCERTAINTIES}

Several problems still must be resolved with regard to the handling of the supernate for TSD. These have to do with EPA, DOE, and DOT regulations regarding the handling, treatment, storage, transportation, and final disposal of $L L W, L L L W$, and mixed waste. To date, the state of Tennessee and the Southeastern Compact currently have no provisions for the treatment or disposal of mixed waste (there are no currently licensed mixed waste treatment or disposal sites in the United States). ${ }^{19}$ In addition, the DOE is not allowed to dispose of waste in commercial facilities because it is not a prudent use of commercial burial facilities. The DOE and other regulatory agencies have not finalized approval to use the LLWDDD classification system for disposal of LLW or mixed waste on the Oak Ridge Reservation. Another factor that will force action in the near 
Table 3. Maximum, minimum, and average radiochemical concentrations in the LLLW tanks

\begin{tabular}{|c|c|c|c|c|c|c|}
\hline \multirow[b]{2}{*}{ Isotope } & \multicolumn{2}{|c|}{ Supernate $\left(n C_{i} / L\right)$} & \multirow[b]{2}{*}{ Avr. } & \multicolumn{2}{|c|}{ Sludge $\left(n C_{i} / L\right)$} & \multirow[b]{2}{*}{ Avg. } \\
\hline & $\operatorname{Max}$. & Min. & & $\operatorname{Max}$. & Min. & \\
\hline \multicolumn{7}{|c|}{ Anelrses of MVSTs } \\
\hline E-3 & $1.67 \pm+04$ & $3.218+04$ & $7.16 E+03$ & M.D.a & & \\
\hline$c-14$ & $2.125 x+04$ & $2.708+01$ & $6.18 E+03$ & $2.87 E+04$ & $3.06 E+03$ & $7.85 E+03$ \\
\hline Co-60 & $3.298+05$ & $8.34 E+03$ & $1.03 E+05$ & $9.12 E+06$ & $2.76 \mathrm{E}+05$ & $1.38 E+06$ \\
\hline SI-90 & $4.732+06$ & $1.12 E+04$ & $1.48 E+06$ & 8. $44 E+07$ & $1.55 E+07$ & $3.67 E+07$ \\
\hline $\mathrm{mb}-95$ & $7.565+03$ & $8.108+02$ & $2.90 E+03$ & $2.53 E+0.5$ & $1.91 E+04$ & $3.44 E+04$ \\
\hline $2 x-95$ & $1.82 E+05$ & $1.408+03$ & $1.66 \mathrm{E}+04$ & $5.42 E+06$ & $5.78 E+04$ & $8.69 E+05$ \\
\hline $8 x-106$ & $1.0225+05$ & 2.97E $\div 04$ & $5.18 E+04$ & $2.24 E+06$ & $1.94 E+05$ & $3.67 E+05$ \\
\hline$C=-134$ & $3.54 E+05$ & $3.628+04$ & $1.49 \mathrm{E}+05$ & $2.64 E+05$ & $2.118+04$ & $4.97 E+04$ \\
\hline$C=-137$ & $5.595+07$ & $5.08 E+06$ & $1.38 \mathrm{E}+07$ & $2.84 E+07$ & $6.52 E+05$ & $9.51 E+06$ \\
\hline Ce-144 & $6.215+04$ & $2.008+04$ & $3.518+04$ & $1.06 E+06$ & $1.33 E+05$ & $2.07 E+05$ \\
\hline Eu-152 & $8.94 E+05$ & $2.515+03$ & $6.67 E+04$ & $4.91 E+07$ & $5.78 E+05$ & $5.75 E+06$ \\
\hline Ev-154 & $4.485+05$ & $1.625+03$ & $3.34 E+04$ & $1.86 \mathrm{E}+07$ & $1.99 \mathrm{E}+05$ & $3.33 E+06$ \\
\hline Eu-155 & $1.41 E+05$ & $1.085+04$ & $2.59 E+04$ & $5.03 E+06$ & $2.72 E+04$ & $8.97 E+05$ \\
\hline Groes alpha & $3.785+04$ & $2.70 E+01$ & $7.125+03$ & $8.15 E+06$ & $5.16 E+05$ & $1.56 \mathrm{E}+06$ \\
\hline Gross beta & $5.94 E+07$ & $5.26 E+06$ & $1.75 E+07$ & $2.41 E+08$ & $4.90 E+07$ & $9.83 E+07$ \\
\hline $\mathrm{U}-232$ & $1.84 E+03$ & $1.08 \mathrm{E}+02$ & $2.28 \varepsilon+02$ & $5.87 E+04$ & $4.97 E+04$ & $6.36 E+03$ \\
\hline$u-233$ & $2.485+04$ & $1.62 E+02$ & $3.55 E+03$ & $4.27 E+05$ & $1.63 \mathrm{E}+04$ & $6.29 E+04$ \\
\hline$U-235$ & N.D. & & & $1.06 E+06$ & $1.26 E+05$ & $2.08 E+05$ \\
\hline $0-238$ & $2.70 E+02$ & $2.70 \mathrm{E}+02$ & $2.70 E+02$ & R.D & & \\
\hline Pus-239/Pu-240 & $1.67 \mathrm{E}+03$ & $1.625+02$ & $1.38 E+02$ & $9.41 E+05$ & $2.99 E+04$ & 8. $61 E+04$ \\
\hline$P u-238 / A m-241$ & $7.05 E+03$ & $4.05 E+02$ & $5.01 E+02$ & $1.94 E+06$ & $8.27 E+04$ & $2.41 E+05$ \\
\hline $0 \cos -243$ & R.D. & & & $9.45 E+05$ & $1.22 E+05$ & $2.05 E+05$ \\
\hline Con-244 & $3.115+04$ & $1.08 E+02$ & $1.92 \mathrm{E}+03$ & $6.04 E+06$ & $1.36 E+05$ & $1.05 E+06$ \\
\hline
\end{tabular}

M.D. = not determined in all tanks. 
Table 4. Maximum, minimum, and average chemical concentrations in the LLLW tanks

\begin{tabular}{|c|c|c|c|c|c|c|}
\hline & \multicolumn{3}{|c|}{ Supernate } & \multicolumn{3}{|c|}{ Sludge } \\
\hline & Max. & Min. & Avs. & Max. & Min. & Avs. \\
\hline $\mathrm{p}$ & 13.1 & 0.56 & 10.75 & & & \\
\hline Density & 1.29 & 1.20 & 1.23 & 1.54 & 1.26 & 1.35 \\
\hline Dissolved solids, ms/mt & 485 & 348 & 386 & & & \\
\hline Total solids, mo/mL & 478 & 334 & 386 & 544 & 369 & 470 \\
\hline Total carbon, $\mu \delta / m L$ & 8,500 & 364 & 1,340 & 22,200 & 1,820 & 10,900 \\
\hline Inorgenic carbon, $M 8 / \mathrm{mI}$ & 8,340 & 1 & 778 & 18,100 & 1,410 & 7,620 \\
\hline Organtc carbon, $\mu s / m L$ & 1,285 & 167 & 565 & 6,480 & 410 & 3,330 \\
\hline Elemantel analysis & $\begin{array}{l}\operatorname{Max} . \\
(\operatorname{mol} L / L)\end{array}$ & $\begin{array}{l}\text { Min. } \\
(m o l / L)\end{array}$ & $\begin{array}{l}\text { Avg. } \\
(\mathrm{mol} / \mathrm{L})\end{array}$ & $\begin{array}{l}\text { Max. } \\
(\operatorname{mol} L / L)\end{array}$ & $\begin{array}{l}\text { Min. } \\
(\mathrm{mol} / \mathrm{L})\end{array}$ & $\begin{array}{l}\text { AvE. } \\
(\mathrm{mol} / \mathrm{L})\end{array}$ \\
\hline Bydroxide & 0.29 & 0.01 & 0.082 & 0.29 & 0.01 & 0.082 \\
\hline Carbonate & & & & 2.02 & 0.15 & 0.85 \\
\hline Chlortde & 0.14 & 0.06 & 0.085 & 0.14 & 0.06 & 0.085 \\
\hline Fluoride & 0.053 & 0.026 & 0.031 & 0.053 & 0.026 & 0.031 \\
\hline Nitrate & 5.97 & 3.23 & 4.38 & 5.97 & 3.23 & 4.38 \\
\hline Phosphate & 0.053 & 0.053 & 0.053 & 0.053 & 0.053 & 0.053 \\
\hline Sulfate & 0.081 & 0.052 & 0.055 & 0.081 & 0.052 & 0.055 \\
\hline Aluminum & $1.70 E-03$ & $4.45 E-05$ & $4.58 E-04$ & $4.28 E-01$ & $4.58 E-02$ & $1.57 \mathrm{E}-01$ \\
\hline Arsente & $5.07 E-05$ & $4.00 \mathrm{E}-05$ & $4.86 E-05$ & $1.34 E-03$ & $5.37 E-04$ & $7.72 E-04$ \\
\hline Bartum & $1.82 z-04$ & $1.38 \varepsilon-06$ & $3.21 E-05$ & $9.76 E-04$ & $1.56 E-04$ & $5.26 E-04$ \\
\hline Boron & $9.25 z-04$ & $1.85 z-05$ & $1.72 E-04$ & $3.10 \mathrm{E}-03$ & $1.40 \mathrm{E}-04$ & $8.73 E-04$ \\
\hline Cadmitum & $4.00 \mathrm{E}-05$ & $1.07 E-06$ & $8.48 \varepsilon-06$ & $5.75 E-04$ & $1.91 E-05$ & $2.15 E-04$ \\
\hline Calctum & 5.74E-01 & $1.10 \mathrm{E}-04$ & 8. $44 E-02$ & $2.00 E+00$ & $4.40 E-01$ & 2. $50 \mathrm{E}+00$ \\
\hline Chromium & $5.19 \mathrm{E}-04$ & $7.31 E-06$ & $9.37 E-05$ & $5.04 E-03$ & $6.54 E-04$ & $2.42 \mathrm{E}-03$ \\
\hline Cobalt & $8.67 E-06$ & M.D. & $5.80 E-06$ & M.D. & & \\
\hline Iron & $4.30 E-03$ & $1.25 E-05$ & $4.68 E-04$ & $6.34 E-02$ & $9.48 E-03$ & $3.30 E-02$ \\
\hline Lead & $3.43 E-05$ & $1.018-05$ & $1.59 \varepsilon-05$ & $3.498-03$ & $7.30 E-04$ & $1.58 E-03$ \\
\hline Magnesium & $2.30 \mathrm{E}-01$ & $5.35 E-05$ & $2.97 \varepsilon-02$ & $0.19 E-01$ & 4. 51E-02 & $4.62 E-01$ \\
\hline Mercury & $4.60 E-06$ & 2.30E-07 & $8.48 E-07$ & $4.92 \Sigma-04$ & $6.92 E-05$ & $2.02 E-04$ \\
\hline Mickel & $2.55 E-04$ & $6.47 E-06$ & $5.10 \mathrm{E}-05$ & $2.51 E-03$ & $3.65 E-04$ & $1.15 E-03$ \\
\hline Potassium & 1.99 & 0.22 & 0.615 & 0.62 & 0.20 & 0.36 \\
\hline Seleaium & $5.95 E-05$ & $2.91 E-05$ & $5.34 E-05$ & $1.07 E-03$ & $4.43 E-04$ & $7.63 E-04$ \\
\hline Silicon & $8.72 E-03$ & $3.56 E-05$ & $9.70 E-04$ & $3.60 E-02$ & $3.60 E-03$ & $9.36 \mathrm{E}-03$ \\
\hline St.1ver & $1.118-05$ & $4.08 E-06$ & $7.118-06$ & $6.49 E-04$ & $7.13 E-05$ & $2.22 E-04$ \\
\hline Sodtum & 4.78 & 2.65 & 3.84 & 4.78 & 2.92 & 3.83 \\
\hline Strontium & $1.83 E-03$ & $4.57 E-06$ & $3.24 E-04$ & $4.44 E-0.3$ & $4.31 E-04$ & $2.16 \varepsilon-03$ \\
\hline Thallium & $6.85 E-06$ & $4.60 E-06$ & $6.40 E-06$ & $1.28 E-04$ & $6.56 \varepsilon-05$ & $9.86 \mathrm{E}-05$ \\
\hline Thorium & $4.10 E-04$ & 4. 31E-06 & $5.77 E-05$ & $8.27 E-02$ & $8.04 E-03$ & $3.20 E-02$ \\
\hline Uranium & $4.75 E-03$ & 4. 20E-07 & $8.05 E-04$ & $1.82 \Sigma-01$ & $7.17 \mathrm{E}-03$ & 4. 39E-02 \\
\hline
\end{tabular}

M.D. - none detected or not analyzed for. 
future is the hazardous waste land disposal ban that establishes treatment standards; prohibits land disposal of wastes, including those in 40 CFR 261.31, dioxin-containing wastes, and California list wastes (liquids with $\mathrm{pH} \leq 2$, those containing PCBs, and liquids or solids containing halogenated organic compounds); and determines a schedule for disposal prohibition and treatment standards. ${ }^{20}$

Because of the low levels of transuranic isotope (TRU) contamination in the supernate (the supernates are not TRU waste per se) and much higher levels in the sludge, disposal at the Waste Isolation Pilot Plant (WIPP) is a possibility. To ensure acceptance at the WIPP, sludge and supernate would be mixed together to meet the minimum TRUcontent WAC. Because RCRA materials are present in the MVST sludges, the TRU waste going to WIPP would be mixed or potentially mixed. An acceptable waste form and the availability of the designed-for capability for remote-handled TRU (RH-TRU) waste are still in question. Also questionable is whether WIPP will be allowed to open fully after the initial 5-year trial period, during which $1 \%$ of the space will be used. If it does receive approval, will it be in a time frame that will benefit the storage problems in the MVSTs? Also, WIPP must receive a "No Migration" variance from the RCRA Land Disposal Restrictions (LDR) from the EPA for storage of RCRA materials if the MVST material is to be disposed of without treatment. If the LDR variance is not granted, the wastes will have to be treated to LDR criteria. Because of these uncertainties, the exact nature of the optimum treatment scheme cannot be determined at present. However, based on the compositions of the various tanks and the expectations for the directions that the regulations will take, some basic steps can be examined.

\section{RESULTS OF DATA-BASE CALCULATIONS}

\subsection{Radiological Results}

Table 3 gives a summary of the maximum, minimum, and average radiochemical concentrations in both supernate and sludge in the LLLW storage tanks. At the time of sampling, the supernate contained $100.5 \mathrm{Ci}$ of ${ }^{60} \mathrm{Co}$ (86.4 $\mathrm{Ci}$ in MVSTs); $13,523 \mathrm{Ci}$ of ${ }^{137} \mathrm{Cs}$ (12,810 $\mathrm{Ci}$ in MVSTs); $1,444 \mathrm{Ci}$ of ${ }^{90} \mathrm{Sr}$ (1,322 $\mathrm{Ci}$ in MVSTs); $6.1 \mathrm{Ci}$ of ${ }^{14} \mathrm{C}(6.0 \mathrm{Ci}$ in MVSTs); $6.92 \mathrm{Ci}$ of gross alpha (3.41 $\mathrm{Ci}$ of alpha in MVSTS); and $4.57 \mathrm{Ci}$ of alpha without ${ }^{24} \mathrm{Cm}\left(3.29 \mathrm{Ci}\right.$ of alpha in MVSTs without ${ }^{244} \mathrm{Cm}$ ). Ninety-two percent of the ${ }^{60} \mathrm{Co}, 94 \%$ of the ${ }^{90} \mathrm{Sr}, 60 \%$ of the ${ }^{14} \mathrm{C}, 99.6 \%$ of the gross alpha (excluding $\mathrm{W}-21$, which was at $\mathrm{pH} 0.71$ and had not been neutralized when sampled and, therefore, contained much soluble alpha), and $98.5 \%$ of the europium are contained in the sludge, while the supernate contains $73.2 \%$ of the ${ }^{137} \mathrm{Cs}$.

Several important observations can be made by comparing the limits in Tables 1 and 2 with concentrations in Table 3 for the alpha-, beta-, and gamma-emitting isotopes present in the LLLW. Most isotopes in the supernate are not in compliance with DOE 5400.5 Derived Concentration Guide (DCG) standards for direct discharge to the environment. Primary concerns for the discharge of liquid waste according to DOE 5400.5 are the gross alpha (TRU components) and the ${ }^{137} \mathrm{Cs},{ }^{60} \mathrm{Co}$, and ${ }^{90} \mathrm{Sr}$, which must be reduced by factors of up to $10^{5}$ to $10^{7}$ for direct liquid discharge. Europium isotopes must also be removed 
from a few tanks, but this should not be a problem since they are expected to be removed in steps that remove the alpha components. Some of the other isotopes listed $\left({ }^{95} \mathrm{Zr},{ }^{95} \mathrm{Nb}\right.$,

${ }^{144} \mathrm{Ce},{ }^{106} \mathrm{Ru}$ ) may need removal for liquid discharge; however, their concentrations, and hence needed removals, are not known accurately because analyses could only give "less than" values that were used in the calculations. Treatment to the DOE 5400.5 standards for drinking water requires an additional decontamination factor of 25 . In addition, the tables show that ${ }^{99} \mathrm{Tc}$ and ${ }^{25 /} \mathrm{Np}$ have limits, but they were not analyzed for and may require measurement and removal. Neptunium-237, in particular, has a very low permissible level.

\subsection{Chemical Composition Results}

Table 4 summarizes the maximum, minimum, and average chemical concentrations of the supernate and sludge in the LLLW tanks. At the time of sampling, about $258,000 \mathrm{gal}$ of supernate $(237,800 \mathrm{gal}$ in MVSTs) and $109,000 \mathrm{gal}(86,600 \mathrm{gal}$ sludge in MVSTs) of sludge required processing. These volumes included about $105,000 \mathrm{~kg}$ of water-insoluble solids and $555,000 \mathrm{~kg}$ of water-soluble solids, primarily sodium and potassium nitrate. The supernate contains $368,630 \mathrm{~kg}$ of soluble salts, including $741 \mathrm{~kg}$ of inorganic carbon and $541 \mathrm{~kg}$ of organic carbon. Maximum levels of the RCRA metals in the supernate were above the levels listed in 40 CFR 261 for arsenic, lead, cadmium, chromium, nickel, and selenium. All of the metals were present in concentrations greater than those allowable in the primary and secondary drinking-water standards, based on the limits of the analytical techniques (also the PWTP and NRWTP WAC). The drinking-water standard for nitrate is $0.00071 \mathrm{M}$, while the concentration present in the LLLW is 3 to $6 \underline{\mathrm{M}}$, a difference of four orders of magnitude. Nitrate is not a RCRA metal or a listed element or compound for solid waste disposal; however, the liquid WAC requirements for the PWTP and NRWTP prohibit levels above 1 and $10 \mathrm{ppm}$ nitrate as nitrogen, respectively; therefore, removal of essentially all of the nitrate is required if the supernate is to be discharged to the PWTP or the NRWTP.

Although the treatment of the sludge in the LLLW storage tanks is not the primary subject of this report, the concentration data for the sludge are reported and some comparisons are made and conclusions drawn. The levels of RCRA metals in the sludge are generally one to three orders of magnitude higher than in the supernate. An additional complication in the sludge analyses for metals is that the recommended EPA toxic material testing process has recently been changed from the Extraction Procedure Toxicity Characteristic (EPTC) to the TCLP; thus, resampling and analysis by TCLP will be required for sludge previously determined to be hazardous by EPTC. ${ }^{21}$ The new definition also adds $\mathbf{2 5}$ organic constituents and the regulatory levels for each constituent. If waste was previously determined to be nonhazardous by EPTC but had metals at concentrations near the regulatory limit, it should also be resampled and analyzed by TCLP. In addition, waste suspected to contain organics must be sampled and analyzed by TCLP. If a sludge is converted to a waste form, such as cement grout, that waste form must pass the TCLP leach test unless a RCRA LDR variance is obtained for the disposal site. 


\subsection{LLLW STORAGE TANK DATA}

The specific data obtained on the material in each tank are shown in Tables A.1-A.10, Appendix A, which give a summary of concentrations and inventories for both radioactive and nonradioactive components. Summations of constituents in the MVSTs and in the ten LLLW tanks are given in Table 5 and Tabie A.11, respectively. The definitions used in the table and the calculational methods are included in Appendix B.

Estimates for the quantities of the various isotopes were calculated, based on the volumes of supernate or sludge, the supernate or sludge density, and the radiological and nonradiological analyses given in the tank sample analyses. ${ }^{3-5}$ Chemical data for the supernate are shown as reported or converted to a molar basis. Radiological data were converted from becquerels per milliliter $(\mathrm{Bq} / \mathrm{mL})$ to nanocuries per liter $(\mathrm{nCi} / \mathrm{L})$. Sludge analyses were presented in units of milligrams per kilogram $(\mathrm{mg} / \mathrm{kg}$ ) and converted to the moles-per-liter (mol/L) concentrations shown, using the measured density of the sludge. For both supernate and sludge, many of the analyses were reported as "less than $\mathrm{mg} / \mathrm{L}$." The concentration was then assumed so that calculations could be made. The estimated concentrations, therefore, result in maximum values for those constituents.

To determine the quantities of soluble and insoluble solids present in the sludge, several assumptions were made, including:

- Soluble nitrate, chloride, and hydroxides were present in the sludge as interstitial liquid at the same concentrations as in the supernate.

- The analyzed cations other than sodium and potassium are present as insoluble compounds with the compounds shown, based on common precipitates at the conditions in the tanks.

- The carbonate was present as calcium carbonate, and the reported value was derived from the inorganic carbon analyses.

The total sludge and supernate quantity of an element or compound were based on the supernate elemental total plus that element's part of the total mass of that sludge compound. The sludge values for mass present are estimates, assuming that the cations are present as the compounds shown. This method was used to compare the analytical physical characterization and to estimate the quantity of insoluble materials present in the sludge. The total solids calculated in this manner were compared with the measured solids; and the difference, called "solids unaccounted for," was used to measure the accuracy of the estimation of the solids composition. Other assumptions are listed in Appendix B.

The total amounts of individual radioactive constituents in the supernate differ markedly from tank to tank. The quantities of ${ }^{60} \mathrm{Co}$, for instance, vary from less than $1 \mathrm{Ci}$ in tank W-27 to almost $40 \mathrm{Ci}$ in tank W-28. The quantity of ${ }^{137} \mathrm{Cs}$ ranges from $195 \mathrm{Ci}$ in $\mathrm{W}-23$ to $6338 \mathrm{Ci}$ in $\mathrm{W}-26,{ }^{14} \mathrm{C}$ ranges from $2 \mathrm{mCi}$ in W-21 to $2.7 \mathrm{Ci}$ in $\mathrm{W}-24,{ }^{90} \mathrm{Sr}$ from 0.2 $\mathrm{Ci}$ in W-23 to $788 \mathrm{Ci}$ in W-28, and gross alpha from $3 \mathrm{mCi}$ in W-27 to $4.37 \mathrm{Ci}$ in W-21. Some tanks have low concentrations of gross alpha; thus, a differentiated alpha analysis was not performed. Variability of this type from tank to tank necessitates planning the decontamination of the LLLW carefully to ensure compliance with all of the various waste TSD rules, orders, and laws. 
Table 5. Summation of constituents in the MVSTs

A. Rediochenical Analyses

\begin{tabular}{|c|c|c|c|c|c|}
\hline Constituent & & & $\begin{array}{c}\text { MVIs supernate } \\
\text { (total Ci) }\end{array}$ & $\begin{array}{l}\text { MVSTs sludge } \\
\text { (total Ci) }\end{array}$ & $\begin{array}{r}\text { MVSTs supernate } \\
+ \text { sludge (Ci) } \\
\end{array}$ \\
\hline 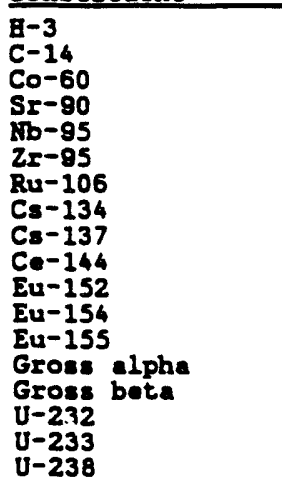 & & & $\begin{array}{r}6.38 \\
6.02 \\
86.52 \\
1,323.94 \\
2.55 \\
4.62 \\
45.84 \\
135.28 \\
12.814 .88 \\
31.17 \\
11.09 \\
5.50 \\
16.46 \\
3.43 \\
15,099.12 \\
0.11 \\
2.83 \\
0.03\end{array}$ & $\begin{array}{r}3.25 \\
572.26 \\
15.182 .96 \\
14.26 \\
359.72 \\
151.86 \\
20.60 \\
3.938 .11 \\
85.62 \\
2.379 .23 \\
1.378 .85 \\
371.40 \\
645.12 \\
40.696 .25 \\
2.63 \\
26.04\end{array}$ & $\begin{array}{r}6.38 \\
9.26 \\
658.77 \\
16,506.90 \\
16.81 \\
364.34 \\
197.71 \\
155.88 \\
16,752.99 \\
116.79 \\
2,390.32 \\
1.384 .35 \\
387.86 \\
648.56 \\
56,795.37 \\
2.74 \\
28.87 \\
0.03\end{array}$ \\
\hline $\begin{array}{l}U-235 \\
P u-239 / P u-240 \\
P u-238 / A m-241 \\
C m-243 \\
C m-244 \\
\end{array}$ & & & $\begin{array}{l}0.03 \\
0.05\end{array}$ & $\begin{array}{r}85.99 \\
35.64 \\
99.79 \\
84.84 \\
435.25 \\
\end{array}$ & $\begin{array}{r}85.99 \\
35.67 \\
99.84 \\
84.84 \\
435 . \\
\end{array}$ \\
\hline $\begin{array}{l}\text { Tank volume } \\
\text { Supermate volume } \\
\text { Supermate } \mathrm{B}_{2} \mathrm{O} \\
\text { Sludse volume } \\
\text { Sludge } \mathrm{B}_{2} \mathrm{O}\end{array}$ & $\begin{array}{r}1,230,463 \mathrm{I} \\
901,411 \mathrm{I} \\
761,938 \mathrm{I} \\
328,952 \mathrm{I} \\
237,643 \mathrm{I}\end{array}$ & $\begin{array}{l}\text { Sum Co,Cs }{ }^{E u} \\
\text { Sum Sr,C, } 3 \mathrm{~B} \\
\text { Sum alpha } \\
\text { Sum elpha-244 Cm }\end{array}$ & $\begin{array}{rr}= & 13,069.73 \\
& =\quad 1,336.34 \\
& =\quad 3.05 \\
m & 3.05\end{array}$ & $\begin{array}{r}8,660.45 \\
15,186.21 \\
770.18 \\
334.93\end{array}$ & $\begin{array}{r}21.730 .18 \\
16,522.54 \\
773.23 \\
337.98\end{array}$ \\
\hline
\end{tabular}

B. Ftrgeicel/Cheaical Analyses

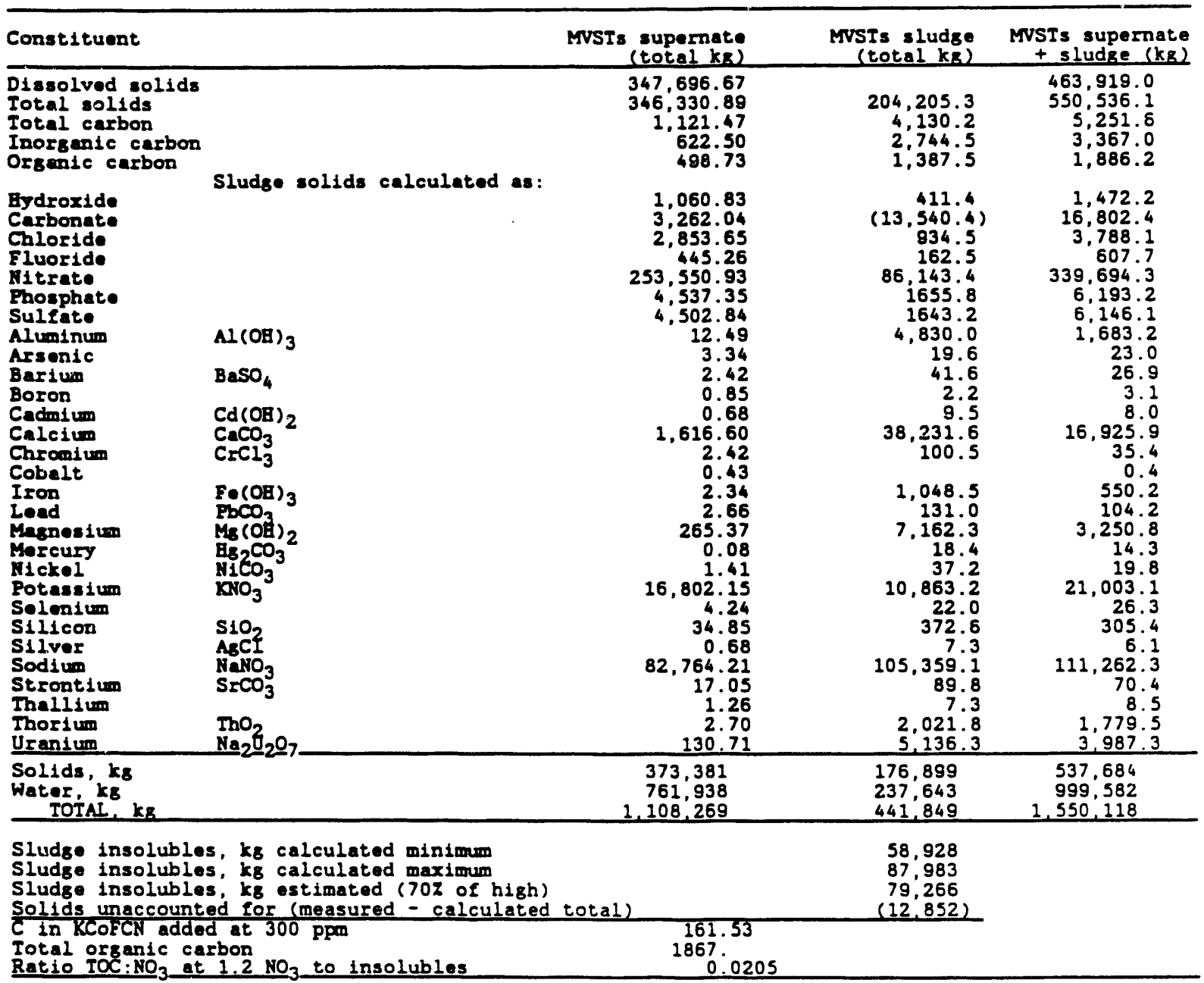




\subsection{TREATMENT REQUIREMENTS}

Based on these data, the required reductions of supernate activity for individual components were calculated, assuming various scenarios for the disposition of the resulting treated product. The activity reduction factors (ARFs) for various components are the total decontamination required and the product of the decontamination factor (DF = $\left.C_{0} / C\right)$ achieved by waste processing times any dilution factor between the LLLW as it exists now and the final volume discharged to the environment. Table 6 is a summary of the maximum, minimum, and average activity reduction factors required for the supernate to meet the various liquid and solid waste discharge and disposal regulations.

Table 6. Required activity reduction factors to meet various standards

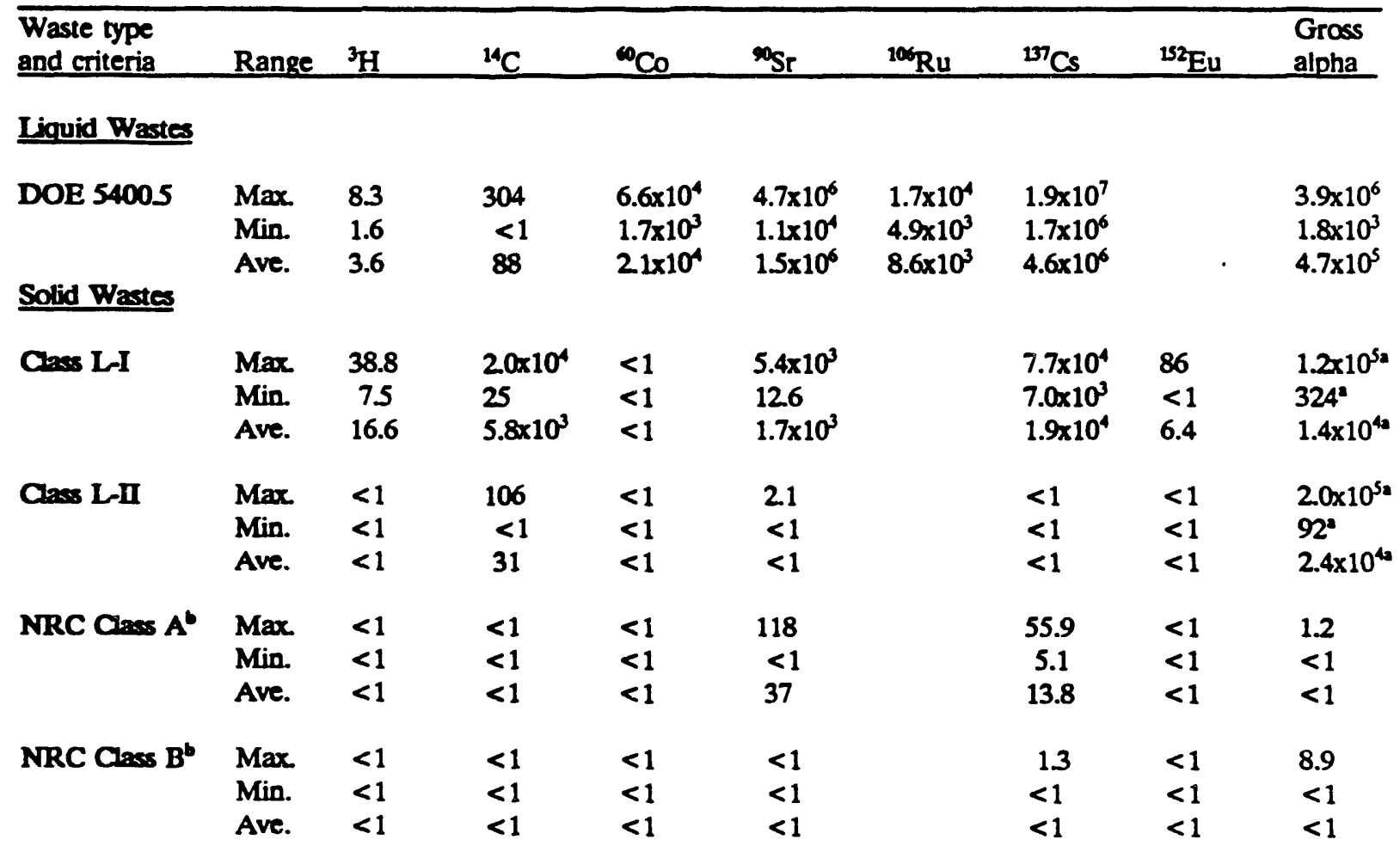

NRC Cass $C^{\dagger}$ No DF is required to meet NRC Class $C$ requirements

'Gross alpha is assumed to be ${ }^{209} \mathrm{Pu}$, the most restricted alpha emitter for Classes L-I and L-II.

'NRC limits are not presently applicable . DOE facilities but are presented for comparison. 
These data indicate that decontamination of the supernate for disposal as a liquid waste through the PWTP will require removal of most of the radioactive cesium contained in the tanks. Quantities of ${ }^{90} \mathrm{Sr},{ }^{60} \mathrm{Co},{ }^{14} \mathrm{C}$, and TRU contaminants may also require removal, depending on the tank in question, for release to the PWTP. The amount of TRU material in the supernate ( $<10 \mathrm{nCi} / \mathrm{g}$ average) also does not qualify it for classification as a TRU material for purposes of the WIPP waste acceptance criteria, which require $>100 \mathrm{nCi} / \mathrm{g}$ TRU content. ${ }^{2}$ In order for the supernate to be classified as TRU waste, the tank contents (including the insoluble sludge) would have to be processed as a homogenous mixture. Without removal of the ${ }^{137} \mathrm{Cs}$ and ${ }^{90} \mathrm{Sr}$, and possibly some of the ${ }^{60} \mathrm{Co}$, this material would be a RH-TRU waste. If WIPP did not accept RH-TRU waste, there would be no place for disposal of the solidified $\mathrm{RH}$ supernate. Currently proposed (May 1990) NUS Class L-II LDR could not be met by solidifying the supernate in grout because of ${ }^{14} \mathrm{C}$ and TRU contamination. In addition, the solidified mixture would have to be tested to determine whether it would be classified as a mixed waste because of the presence of RCRA materials and radioactive contamination in the original waste.

To meet DOE 5400.5 for LLLW treatment for release to the PWTP, the concentrations of radionuclides must be reduced by factors of less than 10 for ${ }^{3} \mathrm{H} ; 10^{2}$ for ${ }^{14} \mathrm{C} ; 10^{4}$ for ${ }^{60} \mathrm{Co}$ and ${ }^{106} \mathrm{Ru} ; 10^{5}$ to $10^{6}$ for ${ }^{90} \mathrm{Sr}$ and gross alpha; and $10^{7}$ for ${ }^{137} \mathrm{Cs}$. In addition to the limits for the individual radionuclides, DOE 5400.5 also restricts the total content of the summation of the concentration divided by the DCG limits to $<1$. The NUS Class L-I reductions for solid LLW require reduction of $\left\langle 10^{2}\right.$ for ${ }^{3} \mathrm{H} ; 10^{3}$ to $10^{4}$ for ${ }^{14} \mathrm{C}$, ${ }^{90} \mathrm{Sr}$, and ${ }^{137} \mathrm{Cs}$; and up to $10^{5}$ for alpha. NUS Class L-II limits require reductions only for ${ }^{14} \mathrm{C}$ $(-100)$ and gross alpha $\left(10^{4}\right.$ to $\left.10^{5}\right)$. In comparison, NRC regulations for commercial nuclear waste materials require reductions only for strontium, cesium, and some alpha for Class A, only alpha for Class B, and no reductions for Class $C$, assuming a waste form such as grout with a density of $2 \mathrm{~g} / \mathrm{cm}^{3}$.

One scenario considered includes feeding the treated liquid (DOE Order 5400.5) to the PWTP (which ciischarges to the NRWTP) with subsequent release of the treated supernate to White Oak Creek through the NPDES permit. The LLLW can also be treated by solidifying the supernate, along with some sludge in sodium nitrate salt cake, for disposal at WIPP. Alternatively, the LLLW can be solidified by formulating it into a cement grout to meet NUS L-I, L-II, or L-IV limits. The appropriate regulatory limits were used when known (10 CFR 20, DOE 5400.5, 10 CFR Part 61, Class A, B, or C) or assumed when not known or not yet finalized, such as the WAC for Class L-I and L-II solid waste for on-site disposal and the NPDES permit discharge limits for liquid disposal. 


\subsubsection{Treatment for Liquid Wastes}

Table 7 shows the ARFs required to meet the requirements of DOE Order 5400.5 for the possible radionuclides that are known to be present in each of the tanks. Europium must be removed from the liquids in only two tanks (W-28 and W-21), while ${ }^{106} \mathrm{Ru}$ must be removed from four of the tanks (W.24, W-26, W-28, and W-23), although DFs are generally $10^{3}$ to $10^{4}$ for all the tanks. Uranium -232 and $-233,{ }^{239} \mathrm{Pu}$, and ${ }^{241} \mathrm{Am}$ are present in high concentrations in W-26, W-21, and W-23, while the ${ }^{244} \mathrm{Cm}$ content is high in W-21

Table 7. ARFs to treat supernate to DOE 54005 DCG standards and to the WAC for the NRWTP

\begin{tabular}{|c|c|c|c|c|c|c|c|c|c|c|}
\hline Const 1tuent & W24 & w25 & 126 & 127 & 128 & 129 & W30 & H31 & 621 & W23 \\
\hline$B-3$ & 4.2 & 4.7 & 8.3 & 2.8 & 1.6 & 2.1 & 2.7 & 2.7 & 4.7 & 1.6 \\
\hline$C-14$ & 304 & 127 & 47 & 70 & 64 & 43 & 35 & 34 & $<1$ & 24 \\
\hline Co-60 & $1.8 E+03$ & $1.0 E+04$ & $6.6 z+04$ & $1.7 E+03$ & 4. $7 E+04$ & 1. $t E+03$ & $3.4 E+03$ & $2.68+03$ & $4.6 E+04$ & $3.4 E+03$ \\
\hline $8 x-\infty 0$ & $2.5 x+04$ & $5.3 E+05$ & $1.3 E+04$ & $1.5 x+06$ & 4. $\pi x+06$ & $2.0 z+05$ & $1.9 E+05$ & $1.8 E+05$ & $2.0 E+06$ & $1.18+04$ \\
\hline$m-95$ & 189 & 43 & $\boldsymbol{\infty}$ & 20 & 81 & 22 & 43 & 37 & 101 & 68 \\
\hline $2 x-95$ & 338 & 81 & 182 & 35 & 148 & 38 & 68 & 66 & $4.8 E+03$ & 68 \\
\hline Pn-106 & $5.0 x+04$ & 8. $6 x+03$ & $1.35+04$ & $5.02+03$ & $2.45+04$ & 4. $2 x+03$ & $0.225+03$ & 8.6x+03 & $8.8 z+03$ & $1 . \pi E+04$ \\
\hline$C s-134$ & 1. acto4 & $5.12+04$ & 1. actos & $2.25+03$ & $1.45+05$ & 6. $0 E+03$ & $3.45+04$ & $2.72+04$ & $6.92+04$ & $6.2 E+04$ \\
\hline$C=-137$ & $2.0 x+06$ & 2. $9 x+06$ & $1.92+07$ & 1. $0 x+06$ & $5.12+06$ & 2. $12+06$ & $2.08+06$ & 1. $7 E+06$ & 2. $9 E+06$ & 3.0E+06 \\
\hline$C 0-144$ & 2. $25+03$ & $5.08+03$ & 8.ex+o3 & 2. $2 x+03$ & $6.9 x+03$ & $30 E+03$ & $5.18+03$ & 4. $2 x+03$ & $5.8 E+03$ & $6.2 E+03$ \\
\hline Lu-152 & 432 & 226 & 284 & 148 & $2.35+03$ & 26 & 284 & 270 & $4.5 x+04$ & 283 \\
\hline $2 u-154$ & 81 & 162 & 324 & 80 & $1.08+03$ & $\infty$ & 194 & 162 & $2.2 E+04$ & 216 \\
\hline Eu-155 & 108 & 186 & 324 & 108 & 251 & 113 & 194 & 179 & $1.4 E+03$ & 230 \\
\hline In-nat & 9.7 & 9.7 & 441 & 210 & 9.7 & 4.4 & 4.4 & 71 & 410 & 69 \\
\hline D-ant & 11 & $<1$ & $1.38+03$ & $<1$ & $<1$ & 5.1 & 6.8 & $<1$ & 900 & 20 \\
\hline $0-232^{2}$ & & & $9.7 z+03$ & & & & & & $1.85+04$ & 1. $1 E+03$ \\
\hline $8-233^{\circ}$ & & & $5.0 z+04$ & & & & & & $2.18+04$ & 324 \\
\hline $0-238^{*}$ & & & 540 & & & & & & & \\
\hline Pu-239/240 & & & 135 & & & & & & 837 & 81 \\
\hline \multirow{2}{*}{\multicolumn{3}{|c|}{$\begin{array}{l}0-241 / P u-238^{\circ} \\
0-244^{\circ}\end{array}$}} & 1. $4 E+04$ & & & & & & $2.3 E+05$ & $3.5 E+04$ \\
\hline & & & & & & & & & $5.2 E+05$ & $1.8 E+03$ \\
\hline Grose elpho & $9.0 \mathrm{E}+03$ & $3.6 E+03$ & $1.95+06$ & 1. $8 \mathrm{E}+03$ & 7. $05+04$ & $1.82+04$ & $1.8 E+04$ & $1.8 E+04$ & $3.9 \mathrm{E}+06$ & $1.5 E+05$ \\
\hline \multicolumn{11}{|c|}{ (40 CRR 261 BCon Hotals Reoval Requiremants) } \\
\hline$\Delta 8$ & $<1$ & $<1$ & $<1$ & $<1$ & $<1$ & $<1$ & $<1$ & $<1$ & $<1$ & $<1$ \\
\hline$\Lambda$ & $<1$ & $<1$ & $<1$ & $<1$ & $<1$ & $<1$ & $<1$ & $<1$ & $<1$ & $<1$ \\
\hline Be & $<1$ & $<1$ & $<1$ & $<1$ & $<1$ & $<1$ & $<1$ & $<1$ & $<1$ & $<1$ \\
\hline $\mathbf{H}$ & $<1$ & $<1$ & $<1$ & $<1$ & $<1$ & $<1$ & $<1$ & $<1$ & $<1$ & $<1$ \\
\hline cd & $<1$ & $<1$ & 4.5 & $<1$ & $<1$ & $<1$ & $<1$ & $<1$ & 2.0 & 1.7 \\
\hline Cx & $<1$ & $<1$ & $<1$ & $<1$ & $<1$ & $<1$ & $<1$ & 1.3 & 5.4 & $<1$ \\
\hline $\mathrm{B}_{8}$ & $<1$ & $<1$ & $<1$ & $<1$ & $<1$ & $<1$ & $<1$ & $<1$ & 4.6 & $<1$ \\
\hline Fb & 1.3 & $<1$ & $<1$ & $<1$ & $<1$ & $<1$ & $<1$ & $<1$ & 1.4 & $<1$ \\
\hline s。 & 4.7 & 4.7 & 4.7 & 4.7 & 4.7 & 4.7 & 4.7 & 4.7 & 2.3 & 2.3 \\
\hline II & 1,5 & 1.5 & 1.5 & 1.5 & 1.5 & 1.5 & 1,5 & 1,5 & 1.0 & 1.0 \\
\hline
\end{tabular}


and W-23. Required gross alpha decontamination factors are all in the $10^{3}$ to $10^{6}$ range. Further analytical work will be required to determine whether any of the individual alphaemitters will require decontamination. Since the ${ }^{134} \mathrm{Cs}$ concentrations are generally $1 \%$ or less of the ${ }^{137} \mathrm{Cs}$ concentrations, have similar allowable limits, and are reduced by the same processes, they can generally be "lumped together" for design purposes. Table 8 lists the ARFs for treatment of radioactivity to drinking-water standards. These standards are only $4 \%$ of the DOE Order 5400.5 requirements and, thus, result in a 25 -fold increase of the ARFs for 5400.5. Although these standards apply to the waste after it enters the Clinch River and is thereby diluted, they are shown for comparison.

The RCRA metal concentrations (see Table 7) indicate that small removals would be required for $\mathrm{Cd}, \mathrm{Cr}, \mathrm{Pb}, \mathrm{Se}, \mathrm{Tl}$, and $\mathrm{Hg}$, depending on the tank. Primary and secondary drinking-water standards requirements are given in Table 8 and show that, by far, the largest problem is nitrate removal; $\mathrm{Cd}, \mathrm{Cr}, \mathrm{Se}$, and $\mathrm{Fe}$ also present problems in selected tanks. For many of the RCRA metals, the values shown in the tables are the maxima because the analyses gave "less than" values that were used for the calculations.

The ARFs in Tables 9-12 are calculated for releasing the treated supernate to White Oak Creek (WOC) through an NPDES permit or through the PWTP or the NRWTP. Table 9 shows reductions required for general release to WOC, based on 10 CFR 20, Appendix B, Table II, Column 2, but do not necessarily reflect the current NPDES permit values. The greatest reductions are required for ${ }^{90} \mathrm{Sr},{ }^{137} \mathrm{Cs}$, and gross alpha, with lesser reductions for ${ }^{60} \mathrm{Co},{ }^{106} \mathrm{Ru},{ }^{144} \mathrm{Ce}$, and Eu. These same general trends were also observed with DOE Order 5400.5.

If any of the LLLW from the MVSTs were qualified for release, it would have to pass through the PWTP. Table 10 shows the ARFs required to meet the WAC for liquids to be treated there. In this case, ${ }^{137} \mathrm{Cs},{ }^{60} \mathrm{Co},{ }^{106} \mathrm{Ru}$, and gross alpha are the isotopes requiring the greatest removal. Strontium-90 has lower ARFs than in earlier tables because it is removed in the PWTP. In addition to the radioactive components, nitrate, phosphate, and sulfate require major treatment to meet the PWTP WAC. Following the PWTP, the waste flows to the NRWTP; the ARFs required to meet the WAC for the NRWTP are shown in Table 11. The WAC are essentially the DOE Order 5400.5 limits for radioisotopes, so ${ }^{60} \mathrm{Co},{ }^{90} \mathrm{Sr},{ }^{137} \mathrm{Cs}$, ${ }^{106} \mathrm{Ru}$, and alpha removal are required. Nitrate and sulfate are also limited, and the total organic carbon requires some treatment. 
Table 8. ARFs to treat supernate to DOE 5400.5 DCG drinking-water standards

\begin{tabular}{|c|c|c|c|c|c|c|c|c|c|c|}
\hline Constituont & W24 & W25 & W26 & W27 & W28 & W29 & W30 & W31 & W21 & W23 \\
\hline B-3 & 104 & 116 & 209 & 71 & 40 & 53 & 68 & 68 & 118 & 40 \\
\hline$C-14$ & $7.6 \mathrm{E}+03$ & $3.2 E+03$ & $1.2 E+03$ & $1.8 E+03$ & $1.6 \mathrm{E}+03$ & $1.1 E+03$ & 874 & $8.5 E+03$ & 9.6 & 612 \\
\hline Co-60 & $4.4 E+04$ & $2.5 E+05$ & $1.6 \mathrm{E}+06$ & $4.2 E+04$ & $1.2 E+06$ & $4.4 E+04$ & $8.4 E+04$ & $6.6 \mathrm{E}+04$ & $1.2 E+06$ & $8.4 E+04$ \\
\hline$S_{r}-90$ & $6.2 E+05$ & $1.3 E+07$ & $3.3 E+05$ & $3.8 E+07$ & $1.2 E+08$ & $5.0 \mathrm{E}+07$ & $4.8 E+06$ & $4.5 E+06$ & $5.0 E+07$ & $2.8 E+05$ \\
\hline $\mathrm{Wb}-95$ & $4.78+03$ & $1.1 E+03$ & $2.4 E+03$ & $5.1 E+02$ & $2.0 \mathrm{E}+03$ & $5.6 E+02$ & $1.1 \mathrm{E}+03$ & 9. $3 E+02$ & $2.5 E+03$ & $1.7 \varepsilon+03$ \\
\hline $2 x-95$ & $8.4 E+03$ & $2.0 E+03$ & $4.6 E+03$ & $8.8 E+02$ & $3.7 E+03$ & $9.6 \Sigma+02$ & $1.78+03$ & $1.7 E+03$ & $1.2 E+05$ & $1.7 E+03$ \\
\hline Ru-106 & $1.2 E+06$ & $2.1 E+05$ & $3.2 E+05$ & $1.2 E+05$ & $3.4 E+05$ & $1.2 E+05$ & $2.3 E+05$ & 2. $1 E+05$ & $2.2 E+05$ & 4. $2 E+05$ \\
\hline Cs-134 & $4.5 E+05$ & $1.3 E+06$ & $4.4 E+06$ & $5.4 E+05$ & $3.6 E+06$ & $1.7 \mathrm{E}+06$ & $8.6 E+05$ & $6.8 E+05$ & $1.7 E+06$ & $1.6 E+06$ \\
\hline$C:-137$ & $5.0 E+07$ & $7.4 E+07$ & $4.7 E+08$ & $4.98+07$ & $1.3 E+08$ & $5.2 E+07$ & $4.98+07$ & $4.2 E+07$ & $7.2 E+07$ & $9.8 E+07$ \\
\hline$C 0-144$ & $7.2 E+04$ & $1.3 E+05$ & $2.2 E+05$ & $7.2 E+04$ & $1.7 E+03$ & $7.5 E+04$ & $1.3 E+05$ & $1.2 E+05$ & $1.4 E+05$ & $1.5 E+05$ \\
\hline Eu-152 & $1.12+04$ & $5.4 E+03$ & $7.18+03$ & $3.7 E+03$ & $5.6 E+04$ & $3.18+03$ & $7.18+03$ & $6.8 E+03$ & $1.1 E+06$ & $7.1 E+03$ \\
\hline Eu-154 & $2.0 \mathrm{E}+03$ & $4.2 E+03$ & B. $1 E+03$ & $2.2 E+03$ & $2.5 E+04$ & $2.2 E+03$ & $4.8 E+03$ & $4.0 E+03$ & $5.6 E+05$ & $5.4 E+03$ \\
\hline Eu-155 & 2. $7 E+03$ & $4.7 E+03$ & 8. $1 E+03$ & $2.7 E+03$ & $6.3 E+03$ & $2.8 E+03$ & $4.9 E+03$ & $4.5 E+03$ & $3.5 E+04$ & $5.7 E+03$ \\
\hline Th-nat & 240 & 240 & $1.18+03$ & $5.4 E+03$ & 2. $4 E+02$ & $1.1 E+03$ & $1.1 E+03$ & $1.8 E+03$ & $1.0 E+04$ & $1.7 E+03$ \\
\hline U-nat & 270 & 3 & $3.3 E+04$ & 3.0 & 3.0 & 130 & 170 & 7.7 & $2.2 E+04$ & 500 \\
\hline$v-232^{a}$ & & & $2.4 E+05$ & & & & & & $4.6 E+05$ & $2.7 E+04$ \\
\hline$U-233^{a}$ & & & $1.28+06$ & & & & & & $5.4 E+05$ & $8.1 E+03$ \\
\hline$U-238^{\circ}$ & & & $1.4 E+04$ & & & & & & & \\
\hline Pu-238/240 & & & $3.4 E+03$ & & & & & & $2.1 E+04$ & $2.0 E+03$ \\
\hline$A m-241 / P u-236$ & & & $3.4 E+05$ & & & & & & $5.9 E+06$ & $8.8 E+05$ \\
\hline $\mathrm{Com}-244^{\circ}$ & & & & & & & & & $1.3 E+07$ & $4.5 E+04$ \\
\hline Grose alphe 2 & $2.2 E+05$ & $9.0 E+04$ & $4.6 E+07$ & $4.5 E+04$ & $2.0 E+06$ & $4.5 E+05$ & $4.5 E+05$ & $4.5 E+04$ & $9.6 E+07$ & $3.7 E+06$ \\
\hline
\end{tabular}

(40 CFR 141.11 Primary Drinkins Whater and 40 GrR 143.3 Secoodery Drinking Water)

\begin{tabular}{|c|c|c|c|c|c|c|c|c|c|c|}
\hline $\mathrm{NO}_{3}$ & 5868 & 5869 & 4608 & 6331 & 8362 & 6331 & 6331 & 6093 & 7003 & 4524 \\
\hline Cd & 22 & 12 & 450 & 12 & 51 & 12 & 12 & 12 & 200 & 170 \\
\hline Cr & 62 & 38 & 36 & 56 & 8 & 120 & 48 & 58 & 540 & 8 \\
\hline $\mathbf{P b}$ & 134 & 42 & 64 & 42 & 42 & 42 & 44 & 54 & 142 & 54 \\
\hline$A_{B}$ & 14 & 14 & 24 & 14 & 14 & 14 & 14 & 14 & 24 & 9 \\
\hline As & 74 & 74 & 74 & 74 & 74 & 74 & 74 & 74 & 76 & 60 \\
\hline Ba & $<1$ & 3 & $<1$ & 4 & 6 & 4 & 1 & $<1$ & 25 & $<1$ \\
\hline S• & 470 & 470 & 470 & 470 & 470 & 470 & 470 & 470 & 230 & 230 \\
\hline B: & 23 & 27 & 40 & 24 & 70 & 75 & 45 & 50 & 460 & 35 \\
\hline Cl & 10 & 10 & 14 & 10 & 20 & 10 & 12 & 11 & 8 & 14 \\
\hline $\mathrm{SO}_{4}$ & 20 & 20 & 20 & 20 & 20 & 20 & 20 & 20 & 20 & 31 \\
\hline$F_{\bullet}$ & 8 & 8 & 9 & 9 & 9 & 9 & 9 & 9 & 800 & 2 \\
\hline
\end{tabular}

Blanks indicate no analytical data are available. 
Table 9. Supernate ARFs for 10 CFR 20 standards for release to White Oak Creek

\begin{tabular}{|c|c|c|c|c|c|c|c|c|c|c|}
\hline Constituent & W24 & พ25 & W26 & W27 & N28 & W29 & W3O & W31 & W21 & พ23 \\
\hline $\begin{array}{l}E-3 \\
C-14\end{array}$ & $\begin{array}{r}2.8 \\
26.6\end{array}$ & $\begin{array}{r}3.1 \\
11.1\end{array}$ & $\begin{array}{l}5.6 \\
4.2\end{array}$ & $\begin{array}{l}1.9 \\
6.1\end{array}$ & $\begin{array}{l}1.1 \\
5.6\end{array}$ & $\begin{array}{l}1.4 \\
3.8\end{array}$ & $\begin{array}{l}1.8 \\
3.1\end{array}$ & $\begin{array}{l}1.8 \\
3.0\end{array}$ & $<1.1$ & $\begin{array}{l}1.1 \\
2.1\end{array}$ \\
\hline Co-60 & 178 & $1.0 E+03$ & $6.6 E+03$ & 167 & $4.7 E+03$ & 174 & 336 & 264 & $4.6 E+03$ & 340 \\
\hline $5 x-90$ & $8.2 E+04$ & $1.8 \mathrm{E}+06$ & 4. $4 E+04$ & $5.0 E+06$ & $1.6 E+07$ & $6.6 \mathrm{E}+0.5$ & $6.4 E+05$ & $6.1 E+06$ & $6.7 E+06$ & $3.7 E+04$ \\
\hline $\mathrm{Mb}-95$ & 76 & 17 & 38 & 8.1 & 32 & $\theta$ & 17 & 14.9 & 40 & 27 \\
\hline $2 x-95$ & 225 & 54 & 121 & 23 & 99 & 26 & 45 & 45 & $3.2 E+03$ & 45 \\
\hline Ru-106 & $3.0 E+04$ & $5.1 E+03$ & $7.6 E+03$ & $3.0 E+03$ & $8.2 E+03$ & $3.0 \mathrm{E}+03$ & $5.5 E+03$ & $5.1 E+03$ & $5.3 E+03$ & $1.0 E+04$ \\
\hline $\mathrm{C}_{8}-134$ & $4.05+03$ & $1.1 E+04$ & $3.9 E+04$ & $4.8 E+03$ & $3.2 E+04$ & $1.5 E+04$ & $7.6 E+03$ & $6.0 E+03$ & $1.5 E+04$ & $1.4 E+04$ \\
\hline Cs-137 & $3.0 \mathrm{E}+05$ & 4. $4 E+05$ & $2.8 E+06$ & $2.9 E+05$ & $7.6 E+05$ & $3.1 E+05$ & $3.0 E+05$ & $2.5 E+05$ & $4.3 E+05$ & $5.9 E+05$ \\
\hline$C 0-144$ & $2.9 E+02$ & $5.0 E+02$ & $8.9 E+02$ & $2.9 E+02$ & $6.9 E+02$ & $3.0 E+02$ & $5.1 E+02$ & 4. $7 E+02$ & $5.8 E+02$ & $6.2 E+02$ \\
\hline Eu-152 & 108 & 54 & 71 & 37 & 564 & 31 & 71 & 68 & $1.1 E+04$ & 71 \\
\hline Eu-154 & 81 & 162 & 324 & 89 & $1.0 \mathrm{E}+03$ & 80 & 194 & 162 & $2.2 E+04$ & 216 \\
\hline Eu-155 & 54 & 83 & 162 & 54 & 226 & 57 & 97 & 90 & 705 & 115 \\
\hline Th-nat & $<1$ & $<1$ & 1.1 & 5.4 & $<1$ & $<1$ & $<1$ & 1.8 & 10 & 1.7 \\
\hline $\begin{array}{l}\text { Unat } \\
\text { U-232b }\end{array}$ & $<1$ & $<1$ & $\begin{array}{l}20 \\
32\end{array}$ & $<1$ & $<1$ & $<1$ & $<1$ & $<1$ & $\begin{array}{l}14 \\
61\end{array}$ & $\begin{array}{l}<1 \\
3.6\end{array}$ \\
\hline $\begin{array}{l}U-233^{b} \\
U-238^{b}\end{array}$ & & & $\begin{array}{l}828 \\
6.8\end{array}$ & & & & & & 356 & 5.4 \\
\hline Pu $-239 / 240^{b}$ & & & 54 & & & & & & 335 & 32 \\
\hline $\mathrm{Pu}-238 / A \omega-241$ & & & 101 & & & & & & $1.7 E+03$ & 263 \\
\hline Cm-264b & & & & & & & & & $4.4 E+03$ & 15 \\
\hline Gross alphe & $4.5 E+03$ & $1.8 \varepsilon+03$ & $9.3 E+05$ & $9.0 \mathrm{E}+02$ & $4.0 E+04$ & $9.0 \mathrm{E}+03$ & $9.0 E+03$ & $9.0 \varepsilon+02$ & $1.9 E+06$ & $7.4 E+04$ \\
\hline
\end{tabular}

Appendix B, Table II, Colum 2.

bianks indicate that no analytical date are available.

Table 10. ARFs to treat supernate to WAC for the PWTP

\begin{tabular}{|c|c|c|c|c|c|c|c|c|c|c|}
\hline Constituont & W24 & W25 & W26 & W27 & W28 & W29 & w30 & W31 & W21 & W23 \\
\hline Co-60 & $1.8 E+03$ & $1.0 E+04$ & $6.6 E+04$ & $1.7 E+03$ & 4. $7 E+04$ & $1.7 E+03$ & $3.4 E+03$ & $2.6 E+03$ & $4.6 E+04$ & $3.4 E+03$ \\
\hline $5 x-90$ & 91 & $1.92+03$ & 49 & $5.6 E+03$ & $1.8 E+04$ & $7.4 E+03$ & $7.1 E+03$ & 672 & $7.5 E+03$ & 41 \\
\hline $\mathrm{Bb}-85$ & 189 & 43 & 84 & 20 & 81 & 22 & 42 & 37 & 101 & 68 \\
\hline $25-95$ & 338 & 81 & 182 & 35 & 148 & 38 & 68 & 68 & $4.8 E+03$ & 68 \\
\hline Ru-106 & $5.0 E+03$ & $8.6 E+03$ & $1.3 E+04$ & $5.0 E+03$ & $1.4 E+04$ & $5.0 E+03$ & $9.2 E+03$ & $8.6 E+03$ & $8.8 E+03$ & $1.7 E+04$ \\
\hline$C=-137$ & $5.5 E+05$ & 8. $2 E+05$ & $5.2 E+06$ & 5. $4 E+05$ & 1. $4 E+06$ & $5.7 E+05$ & $5.5 E+05$ & $4.7 E+05$ & 8. $0 E+05$ & $1.1 E+06$ \\
\hline Eu-152 & 432 & 216 & 284 & 148 & $2.2 E+03$ & 126 & 284 & 270 & 4. $5 E+04$ & 284 \\
\hline$E u-154$ & 81 & 162 & 324 & 89 & $1.0 E+03$ & 90 & 194 & 162 & $2.2 E+04$ & 216 \\
\hline Eu-155 & 108 & 186 & 324 & 108 & 251 & 113 & 194 & 179 & $1.4 E+03$ & 230 \\
\hline Gross alpha & 500 & 200 & $1.0 E+05$ & 100 & $4.4 E+03$ & $1.0 E+02$ & $1.0 \varepsilon+03$ & $1.0 E+03$ & $2.1 E+05$ & $8.2 E+03$ \\
\hline Gross beta & 2. $3 E+04$ & 3. $9 E+04$ & $2.2 E+05$ & $3.3 E+04$ & 9.8E+04 & $3.6 E+04$ & 2. $1 E+04$ & 1. $9 E+04$ & $5.0 E+04$ & $4.6 E+04$ \\
\hline $\mathrm{NO}_{3} \mathrm{a}$ & $5.9 E+04$ & $5.9 E+04$ & $4.6 \tau+04$ & $6.3 E+04$ & $8.4 E+04$ & $6.3 E+04$ & $6.3 E+04$ & $6.1 E+04$ & $7.0 E+04$ & $4.5 E+04$ \\
\hline $\mathrm{PO}_{4}$ & $1.0 E+04$ & $1.0 E+04$ & $1.0 E+04$ & $1.0 E+04$ & $1.0 E+04$ & $1.0 E+04$ & $1.0 E+04$ & $1.0 E+04$ & $1.0 E+04$ & 1. $.0 E+04$ \\
\hline $\mathrm{SO}_{4} \mathrm{a}$ & $5.0 E+04$ & $5.0 E+04$ & $5.0 E+04$ & $5.0 E+04$ & $5.0 E+04$ & $5.0 E+04$ & $5.0 E+04$ & $5.0 E+04$ & $5.0 E+04$ & $7.8 E+04$ \\
\hline Cadmium & $<1$ & $<1$ & 6.4 & $<1$ & $<1$ & $<1$ & $<1$ & $<1$ & 2.9 & 2.4 \\
\hline Chromium & 1.03 & $<1$ & $<1$ & $<1$ & $<1$ & 2.0 & $<1$ & $<1$ & 9.0 & $<1$ \\
\hline Lead & 9.6 & 3.0 & 4.6 & 3.0 & 3.0 & 3.0 & 3.1 & 3.9 & 10 & 3.8 \\
\hline N1ckel & $<1$ & $<1$ & 2.0 & $<1$ & $<1$ & $<1$ & $<1$ & $<1$ & 3.8 & $<1$ \\
\hline S1lver & 1.4 & 1.4 & 2.4 & 1.4 & 1.4 & 1.4 & 1.4 & 1.4 & 2.4 & $<1$ \\
\hline
\end{tabular}

aPTIP WAC are $\mathrm{NO}_{3}=1 \mathrm{ppm} \mathrm{N}$ (assumed for calculation), $\mathrm{PO}_{4}=5 \mathrm{ppm}, \mathrm{SO}_{4}=0.1 \mathrm{ppm}$. 
Table 11. ARFs to treat supernate to the NRWTP WAC for the nonradiuactive components

\begin{tabular}{|c|c|c|c|c|c|c|c|c|c|c|}
\hline Constituent & W24 & W25 & W26 & W27 & W28 & W29 & W30 & W31 & W21 & W23 \\
\hline $\begin{array}{l}\mathrm{TOC} \\
\mathrm{NO}_{3} \mathrm{~b}\end{array}$ & $\begin{array}{r}13 \\
6820\end{array}$ & $\begin{array}{r}12 \\
6820\end{array}$ & $\begin{array}{r}34 \\
5360\end{array}$ & $\begin{array}{r}9.6 \\
7360\end{array}$ & $\begin{array}{r}15 \\
9720\end{array}$ & $\begin{array}{r}12 \\
7360\end{array}$ & $\begin{array}{l}12.8 \\
7360\end{array}$ & $7080^{4.4}$ & $\begin{array}{r}15 \\
8140\end{array}$ & $\begin{array}{r}31 \\
5260\end{array}$ \\
\hline $\mathrm{SO}_{4}$ & 5.3 & 5.3 & 5.3 & 5.3 & 5.3 & 5.3 & 5.3 & 5.3 & 5.3 & 8.3 \\
\hline A8 & 2.7 & 2.7 & 4.6 & 2.7 & 2.7 & 2.7 & 2.7 & 2.7 & 4.6 & 1.7 \\
\hline As & $<1$ & $<1$ & $<1$ & $<1$ & $<1$ & $<1$ & $<1$ & $<1$ & $<1$ & $<1$ \\
\hline Ba & $<1$ & $<1$ & $<1$ & $<1$ & $<1$ & $<1$ & $<1$ & $<1$ & 4.2 & $<1$ \\
\hline Cd & $<1$ & $<1$ & 2.4 & $<1$ & $<1$ & $<1$ & $<1$ & $<1$ & $\therefore .1$ & $<1$ \\
\hline CI & $<1$ & $<1$ & $<1$ & $<1$ & $<1$ & $<1$ & $<1$ & $<1$ & 2.7 & $<1$ \\
\hline F• & $<1$ & $<1$ & $<1$ & $<1$ & $<1$ & $<1$ & $<1$ & $<1$ & 2.3 & $<1$ \\
\hline B8 & 5.1 & 6.0 & 8.9 & 5.3 & 15.6 & 16.7 & 10 & 11.1 & 102 & 7.8 \\
\hline$N 1$ & $<1$ & $<1$ & $<1$ & $<1$ & $<1$ & $<1$ & $<1$ & $<1$ & $<1$ & $<1$ \\
\hline $\mathbf{F b}$ & 1.3 & $<1$ & $<1$ & $<1$ & $<1$ & $<1$ & $<1$ & $<1$ & 1.3 & $<1$ \\
\hline Sn & 1.3 & 1.3 & 1.3 & 1.3 & 1.3 & 1.3 & 1.3 & 1.3 & $<1$ & $<1$ \\
\hline
\end{tabular}

Radioisotope limits are the seme as the DOE 5400.5 DCG limits.

bilmit was assumed to be 1 ppor $N$ for calculation purposes.

Table 12 Supernate DFs to reach the NRWTP WAC with dilution" for the radioactive components by feeding to the PWTP

\begin{tabular}{|c|c|c|c|c|c|c|c|c|c|c|}
\hline Constituent & W24 & W25 & W26 & W27 & W28 & พ29 & W30 & W31 & W21 & W23 \\
\hline B-3 & $<1$ & $<1$ & $<1$ & $<1$ & $<2$ & $<1$ & $<1$ & $<1$ & $<1$ & $<1$ \\
\hline$c-14$ & $<1$ & $<1$ & $<1$ & $<1$ & $<i$ & $<1$ & $<1$ & $<1$ & $<i$ & $<1$ \\
\hline Co-60 & 1.3 & 7.0 & 46.0 & 1.2 & 32.7 & 1.2 & 2.3 & 1.8 & 32 & 2.3 \\
\hline$S=-90$ & 17 & 370 & 0.2 & $1.0 E+03$ & 3. $3 E+03$ & $1.4 E+03$ & 133 & 126 & 1. $4 E+03$ & 7.7 \\
\hline $\mathrm{Nb}-95$ & $<1$ & $<1$ & $<1$ & $<1$ & $<1$ & $<1$ & $<1$ & $<1$ & $<1$ & $<1$ \\
\hline $25-95$ & $<1$ & $<1$ & $<1$ & $<1$ & $<1$ & $<1$ & $<1$ & $<1$ & 3.3 & $<1$ \\
\hline Ru-106 & 3.4 & 6.0 & 8.8 & 3.4 & 9.4 & 3.4 & 6.4 & 5.9 & 6.1 & 11.8 \\
\hline$C s-134$ & 12.6 & 35.3 & 123 & 15.1 & 99.4 & 47.0 & 23.8 & 18.8 & 48 & 43.4 \\
\hline Cs-137 & $4 E+03$ & $2.0 E+03$ & $1.3 E+04$ & $1.4 E+03$ & $3.6 E+03$ & 1. $4 E+03$ & $1.4 E+03$ & $1.2 E+03$ & $2.0 E+03$ & 2. $7 E+03$ \\
\hline$C_{0-144}$ & 2.0 & 3.5 & 6.2 & 2.0 & 4.8 & 2.1 & 3.6 & 3.3 & 4.0 & 4.3 \\
\hline$E u-152$ & $<1$ & $<1$ & $<1$ & $<1$ & 1.6 & $<1$ & $<1$ & $<1$ & 31 & $<1$ \\
\hline Eu-154 & $<1$ & $<1$ & $<1$ & $<1$ & $<1$ & $<1$ & $<1$ & $<1$ & 15.6 & $<1$ \\
\hline Eu-155 & $<1$ & $<1$ & $<1$ & $<1$ & $<1$ & $<1$ & $<1$ & $<1$ & 1.0 & $<1$ \\
\hline Th-nat & $<1$ & $<1$ & $<1$ & $<1$ & $<1$ & $<1$ & $<1$ & $<1$ & $<1$ & $<1$ \\
\hline U-nat & $<1$ & $<1$ & $<1$ & $<1$ & $<1$ & $<1$ & $<1$ & $<1$ & $<1$ & $<1$ \\
\hline$U-232^{b}$ & & & 6.8 & & & & & & 12.8 & $<1$ \\
\hline$U-233^{b}$ & & & 34.5 & & & & & & 14.8 & $<1$ \\
\hline $\mathrm{U}-238^{\mathrm{b}}$ & & & $<1$ & & & & & & & \\
\hline $\mathrm{Bu}-239 / 240^{\mathrm{b}}$ & & & $<1$ & & & & & & $<1$ & $<1$ \\
\hline $\mathrm{Am}-241 / \mathrm{Pu}-238^{\mathrm{b}}$ & & & 8.4 & & & & & & 163 & 24.4 \\
\hline$C 0-244^{b}$ & & & & & & & & & 359 & 1.3 \\
\hline Gross alpha & 6.3 & 2.5 & $1.3 E+03$ & 1.3 & 55 & 1.2 & 12.5 & 12.5 & $2.7 E+03$ & 103 \\
\hline $\mathrm{NO}_{3}(1 \mathrm{ppm} N)$ & 4.7 & 4.7 & 3.7 & 5.1 & 6.8 & 5.1 & 5.1 & 4.9 & 5.7 & 3.6 \\
\hline $\mathrm{SO}_{4}$, IOC & $<1$ & $<1$ & $<1$ & $<1$ & $<1$ & $<1$ & $<1$ & $<1$ & $<1$ & $<1$ \\
\hline $\mathrm{As}_{\mathrm{B}} \mathrm{Cd}, \mathrm{Cr}$ & $<1$ & $<1$ & $<1$ & $<1$ & $<1$ & $<1$ & $<1$ & $<1$ & $<1$ & $<1$ \\
\hline $\mathrm{Pb}, \mathrm{H} 1, \mathrm{Ba}$ & $<1$ & $<1$ & $<1$ & $<1$ & $<1$ & $<1$ & $<1$ & $<1$ & $<1$ & $<1$ \\
\hline As, Se, Fe & $<1$ & $<1$ & $<1$ & $<1$ & $<1$ & $<1$ & $<1$ & $<1$ & $<1$ & $<1$ \\
\hline
\end{tabular}


In order to remove the radioactive constituents, a very small amount of radioactive material must be separated from the large amounts of nonradioactive materials contained in the tanks. For example, ${ }^{137} \mathrm{Cs}$, at $5.9 \times 10^{6} \mathrm{nCi} / \mathrm{L}$, in tank W-27 supernate consists of about $6.0 \times 10^{-5} \mathrm{~g}{ }^{137} \mathrm{Cs} / \mathrm{L}(60 \mathrm{ppb})$ or $4.4 \times 10^{-7} \underline{\mathrm{M}}$, while the sodium is at $4.52 \underline{\mathrm{M}}$ and the potassium is $0.22 \mathrm{M}$. In other words, W-27 contains $-6.6 \mathrm{~g}$ of ${ }^{137} \mathrm{Cs}$, which must be separated from $30,766 \mathrm{~kg}$ of sodium and $933 \mathrm{~kg}$ of potassium. Stable cesium may also be present but was not analyzed. The ${ }^{90} \mathrm{Sr}$ situation is similar for W-27, with a concentration of $1.0 \times 10^{-5} \mathrm{~g} / \mathrm{L}\left(1.1 \times 10^{-7} \mathrm{M}\right)$, or $1.1 \mathrm{~g},{ }^{90} \mathrm{Sr}$ in the supernate. A process that removes ${ }^{90} \mathrm{Sr}$ will also remove the nonradioactive strontium, which amounts ts almos $2 \mathrm{~kg}$ in W-27; however, adaitional removal capacity ( -2000 times that for the ${ }^{90} \mathrm{Sr}$ alone) would be required.

These ARFs do not take into account the dilutions obtained when the treated supernate is fed to the creek or to the treatment facilities, because the TDHE has ruled that ORNL cannot use dilution as a treatment method. If the rules change and the treated supernate is allowed to go through the PWTP and meet the NRWTP WAC, then the DFs shown in Table 12 would be required prior to feed to the PWTP. These DFs are calculated assuming dilution into a stream with a flow rate of $200 \mathrm{gal} / \mathrm{min}$ from the PWTP to the NRWTP and an LLLW feed rate of $200 \mathrm{gal} / \mathrm{d}$ to the PWTP. This results in an activity reduction of 1440 . Nitrate concentrations will have to be reduced to the PWTP WAC before the streams can be mixed. The nuclides that require the most extensive treatment (DFs of $10^{3}$ ) in this scenario include ${ }^{137} \mathrm{Cs}$ and ${ }^{90} \mathrm{Sr}$ for all tanks. Removals of ${ }^{60} \mathrm{Co}$ and ${ }^{106} \mathrm{Ru}$ are also required at DFs of -10 , and the gross alpha is still high in W-26, W-21, and W-23. Nitrate requires a DF of 4 to 9 to meet the NRWTP WAC. Essentially all of the nitrate would have to be removed before the treated supernate could be released to the PWTP if the WAC for the PWTP that prohibits the discharge of nitrate to the plant at levels above $1 \mathrm{ppm}$ nitrogen is enforced.

From the point of view of achieving processing requirements, process DFs corresponding to the larger ARFs of Table 7 (on the order of $10^{6}$ to $10^{7}$ for ${ }^{137} \mathrm{Cs}$ and ${ }^{90} \mathrm{Sr}$ and $10^{4}$ to $10^{5}$ for ${ }^{60} \mathrm{Co}$, gross alpha, and some actinides) might be obtained only with considerable difficulty and at high cost. In such a case, processing the supernate with the objective of environmental discharge is probably not a viable option; instead, a solidification process would probably be favored, resulting in an increased volume of solid waste. However, if dilution can be included, the DF requirements are reduced about three orders of magnitude; in that case, processing the supernate for environmental discharge may be viable. Therefore, the choice as to whether waste processing is advantageous, or even 
technically achievable, depends on the regulatory rules as much as it does on process technology.

\subsection{Treatment Required for Solid LLW}

The requirements for treating the supernate to reach the standards for solid LLW disposal are shown in Tables 13 and 14. These tables are calculated based on the assumption that the supernate is solidified in a grout mixture with a volume increase of 30\%. Results show that NRC Class A standards can be met by removing only ${ }^{137} \mathrm{Cs}$ (with DFs rangirg from 3.9 to 43 ). Also, ${ }^{90} \mathrm{Sr}$ must be removed from all tanks, except for W-24, -26 , and -23 , with DFs ranging from 3.4 to 90.9 . Further, gross alpha contamination must be removed from tanks W-26 (DF = 4.3) and W-21 (DF = 8.9). For NRC Class B LLW, tanks W-26 and W-21 require removal of gross alpha as for class $A$. The individual isotopes ${ }^{238} \mathrm{Pu},{ }^{239} \mathrm{Pu},{ }^{241} \mathrm{Am}$, and ${ }^{24} \mathrm{Cm}$ in $\mathrm{W}-21$ are also above the Class $\mathrm{A}$ and $\mathrm{B}$ limits. No DF is required for any supernate to meet the requirements of NRC Class $C$ if the waste form is grout with a density of $2 \mathrm{~g} / \mathrm{cm}^{3}$.

The DFs required to meet the original LLWDDD proposed limits for solidified supernate for classes L-I, L-II, and L-III are shown in Table 14; the DFs for the proposed NUS Class L-I and Class L-II limits are given in Table 15. The waste forms are assumed to be concrete in which the supernate is solidified at a volume increase of $30 \%$. The NUS limits were proposed by the NUS Corporation in May 1990 for use in the Reservation Waste Management Environmental Impact Statement, using the most restrictive intruder scenario. The scenarios examined included the homesteader (10-mrem limit), drinking water (4-mrem limit), and air pathway to the general public (10-mrem limit). The NUS values are not finalized and may change significantly.

NUS Class L-I requires decontamination for ${ }^{3} \mathrm{H},{ }^{14} \mathrm{C},{ }^{137} \mathrm{Cs}$, and ${ }^{90} \mathrm{Sr}$ for all tanks. The cesium DFs range frnm $5.5 \times 10^{3}$ to $6.0 \times 10^{4}$, and ${ }^{14} \mathrm{C}$ DFs are generally in the $10^{3}$ to $10^{4}$ range, while strontium DFs vary from $\approx 10$ to $1.7 \times 10^{3}$. Cesium- $134,{ }^{106} \mathrm{Ru}$, and ${ }^{242} \mathrm{Cm}$ have inventory limits exceeding $10^{12} \mathrm{Ci}$ and need no DF. The alpha isotopic breakdown for the three tanks W-26, W-21, and W-23 show that removal of alpha contamination is required for ${ }^{233} \mathrm{U},{ }^{238} \mathrm{U},{ }^{238} \mathrm{Pu},{ }^{239} \mathrm{Pu},{ }^{241} \mathrm{Am}$, and ${ }^{244} \mathrm{Cm}$. If the uranium and thorium shown in the lower part of the tables are assumed to be ${ }^{238} \mathrm{U}$ and ${ }^{232} \mathrm{Th}$, the radioactivity represented by them can be calculated and reveals that ${ }^{232} \mathrm{Th}$ is above the limits in all but W-29 and W-30; however, the DFs required are small except in W-21, which was at a low pH level when sampled. Uranium, as ${ }^{238} \mathrm{U}$, is above the limits only in tanks W-26 and W-21. 
Table 13. Supernate DFs to reach NRC Class A, B, and C standards for solid waste forms with a 1.3:1 volume increase

\begin{tabular}{llllllllllll}
\hline Constituent & W24 & W25 & W26 & W27 & W28 & W29 & W30 & W31 & W21 & W23 \\
\hline
\end{tabular}

\section{A. Class A}

$\begin{array}{lcccccccccc}\text { B-3 } & <1 & <1 & <1 & <1 & <1 & <1 & <1 & <1 & <1 & <1 \\ C-14 & <1 & <1 & <1 & <1 & <1 & <1 & <1 & <1 & <1 & <1 \\ \text { Co-60 } & <1 & <1 & <1 & <1 & <1 & <1 & <1 & <1 & <1 & <1 \\ 55-80 & <1 & 13.2 & <1 & 27.6 & 118.1 & 49.8 & 4.8 & 4.3 & 50.3 & <1 \\ C=-137 & 6.0 & 8.8 & 55.9 & 5.8 & 15.3 & 6.2 & 5.9 & 5.1 & 8.6 & 11.8 \\ \text { Gross alpha } & <1 & <1 & 5.6 & <1 & <1 & <1 & <1 & <1 & 11.6 & <1\end{array}$

\section{B. Class B}

$\begin{array}{lllllllllll}\text { B-3 } & <1 & <1 & <1 & <1 & <1 & <1 & <1 & <1 & <1 & <1 \\ \mathrm{C}-14 & <1 & <1 & <1 & <1 & <1 & <1 & <1 & <1 & <1 & <1 \\ \text { Co-60 } & <1 & <1 & <1 & <1 & <1 & <1 & <1 & <1 & <1 & <1 \\ \mathbf{S}-90 & <1 & <1 & <1 & <1 & <1 & <1 & <1 & <1 & <1 & <1 \\ \text { C5-137 } & <1 & <1 & 1.3 & <1 & <1 & <1 & <1 & <1 & <1 & <1 \\ \text { Gross alpha } & <1 & <1 & 5.6 & <1 & <1 & <1 & <1 & <1 & 11.6 & <1 \\ U-233 & <1 & <1 & 5.0 & <1 & <1 & <1 & <1 & <1 & 2.1 & <1 \\ \text { Pu-239 } & <1 & <1 & <1 & <1 & <1 & <1 & <1 & <1 & <1 & <1 \\ \text { Pu-240 } & <1 & <1 & <1 & <1 & <1 & <1 & <1 & <1 & <1 & <1 \\ \text { Pu-238 } & <1 & <1 & <1 & <1 & <1 & <1 & <1 & <1 & 1.4 & <1 \\ \text { Am-241 } & <1 & <1 & <1 & <1 & <1 & <1 & <1 & <1 & 1.4 & <1 \\ \text { Com-244 } & <1 & <1 & <1 & <1 & <1 & <1 & <1 & <1 & 6.2 & <1\end{array}$

\section{Class C}

No DF required for any tanks for any component for Class $C$. 
Table 14. Supernate DFs for LLWDDD Class L-I, L-II, and L-III for concrete waste forms with a 1.3:1 volume increase

\begin{tabular}{|c|c|c|c|c|c|c|c|c|c|c|}
\hline Constituent & : 124 & W25 & พ26 & W27 & W28 & W29 & W30 & W31 & W21 & W23 \\
\hline \multicolumn{11}{|c|}{ A Class $\mathbf{L} \mathbf{I}$} \\
\hline Co-60 & $<1$ & 2.6 & 17.0 & $<1$ & 12.1 & $<1$ & $<1$ & $<1$ & 11.8 & $<1$ \\
\hline$S z-90$ & 20.5 & 438 & 11 & $1.3 E+03$ & $3.9 \mathrm{E}+03$ & $1.7 \mathrm{E}+03$ & 159 & 151 & $1.7 E+03$ & 9.3 \\
\hline$C s-137$ & $.5 E+04$ & $2.2 E+04$ & $1.4 E+05$ & $1.5 E+04$ & $3.85+04$ & $1.5 E+04$ & $1.5 E+04$ & $1.3 E+04$ & 2. $2 E+04$ & $2.9 E+04$ \\
\hline Eu-152 & 10.4 & 5.2 & 6.8 & 3.6 & 54.3 & 3.0 & 6.8 & 6.5 & $1.1 E+03$ & 6.8 \\
\hline Eu- 154 & $<1$ & 1.1 & 2.2 & $<1$ & 6.7 & $<1$ & 1.3 & 1.1 & 151 & 1.5 \\
\hline Th-nat & $<1$ & $<1$ & $<1$ & $<1$ & $<1$ & $<1$ & $<1$ & $<1$ & 1.5 & $<1$ \\
\hline U-nat & $<1$ & $<1$ & 6.0 & $<1$ & $<1$ & $<1$ & $<1$ & $<1$ & 4.1 & $<1$ \\
\hline $\begin{array}{l}u-233^{b} \\
u-238^{b}\end{array}$ & & & $\begin{array}{r}241 \\
2.8\end{array}$ & & & & & & 104 & 1.6 \\
\hline Pu-238b & & & $<1$ & & & & & & 5.6 & $<1$ \\
\hline$P u-239^{b}$ & & & $<1$ & & & & & & 1.1 & $<1$ \\
\hline$A m-241^{b}$ & & & $<1$ & & & & & & 5.6 & $<1$ \\
\hline$C m-244^{b}$ & & & & & & & & & 17.5 & $<1$ \\
\hline \multicolumn{11}{|l|}{ Alphe as } \\
\hline Pu-239 & $<1$ & $<1$ & 18.8 & $<1$ & $<1$ & $<1$ & $<1$ & $<1$ & 39.0 & 1.5 \\
\hline
\end{tabular}

Cesium-134 and 106Ru have no LLWDDD I limits and are not at wn; ${ }^{3 \mathrm{~B}}$, ${ }^{14} \mathrm{C}$, and ${ }^{155_{\text {Eu }} \text { are }}$ <1 for all tanks. bianks indicate that no analytical data are availeble.

\section{B. Class L-Ir}

\begin{tabular}{|c|c|c|c|c|c|c|c|c|c|c|}
\hline SI-90 & $<1$ & $<1$ & $<1$ & 1.9 & 5.8 & 2.5 & $<1$ & $<1$ & 2.5 & $<1$ \\
\hline Cs-137 & 29.8 & 44.1 & 279.2 & 29.1 & 76.3 & 30.9 & 29.5 & 25.4 & 43.0 & 58.8 \\
\hline Th-nat & $<1$ & $<1$ & $<1$ & $<1$ & $<1$ & $<1$ & $<1$ & $<1$ & 1.0 & $<1$ \\
\hline $\mathrm{U}-233^{b}$ & & & 4.4 & & & & & & 1.9 & $<1$ \\
\hline Pu-238b & & & $<1$ & & & & & & 8.5 & 1.3 \\
\hline Pu-239b & & & $<1$ & & & & & & 3.2 & $<1$ \\
\hline$A m-241^{b}$ & & & $<1$ & & & & & & 8.5 & 1.3 \\
\hline $\mathrm{Cm}-244^{\mathrm{b}}$ & & & & & & & & & $<1$ & $<1$ \\
\hline $\begin{array}{l}\text { Alphe as } \\
\text { Pu-239 }\end{array}$ & $<1$ & $<1$ & 53.6 & $<1$ & 2.3 & $<1$ & $<1$ & $<1$ & 111.4 & 4.3 \\
\hline
\end{tabular}

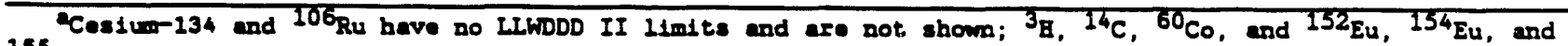
155 Eu are <1 for each tank.

bianks indicate that no analyticel date are available.

\section{Class L-III"}

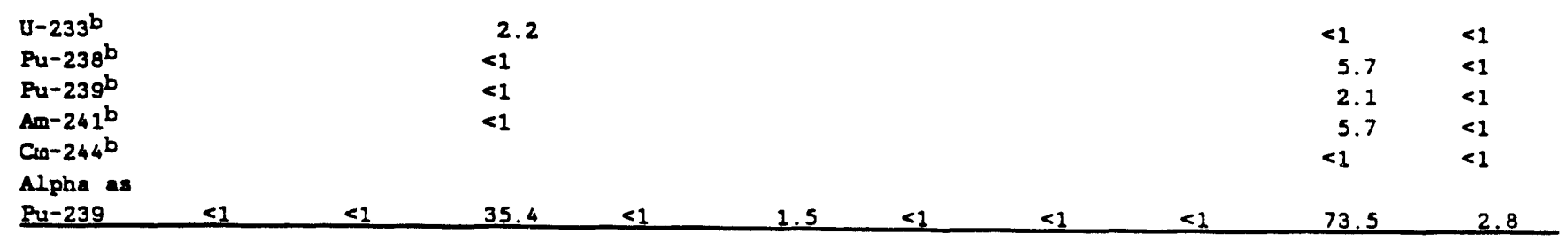

Iritium, ${ }^{60} \mathrm{Co},{ }^{90} \mathrm{~S} s,{ }^{134} \mathrm{Cs},{ }^{137} \mathrm{Cs},{ }^{106} \mathrm{Ru},{ }^{152} \mathrm{Eu},{ }^{154} \mathrm{Eu}$, and ${ }^{155} \mathrm{Eu}$ have no LIWDDD III limits and are not shown; carbon-14 is <1 for each tank.

blanks indicate that no analytical data are available. 
Table 15. Supernate DFs for NUS Class $L-1$ and L-2 limits for concrete waste forms

\section{A. Class L-1}

\begin{tabular}{|c|c|c|c|c|c|c|c|c|c|c|}
\hline Constituen & W24 & W25 & W26 & W27 & W28 & W29 & w3o & W31 & W21 & W23 \\
\hline $\mathbf{z}-3$ & 15 & 17 & 30 & 10 & 5.8 & 7.5 & 9.7 & 9.8 & 17 & 5.8 \\
\hline$c-14$ & $1.5 E+04$ & $6.4 E+03$ & $2.4 E+03$ & $3.5 E+03$ & $3.2 E+03$ & $2.2 E+03$ & $1.8 \mathrm{E}+03$ & $1.7 E+03$ & 19 & $1.2 E+03$ \\
\hline Co-60 & $<1$ & $<1$ & $<1$ & $<1$ & $<1$ & $<1$ & $<1$ & $<1$ & $<1$ & $<1$ \\
\hline$S r-90$ & 21.5 & 460 & 12 & $1.3 E+03$ & 4. $2 E+03$ & $1.7 E+03$ & 167 & 159 & $1.8 E+03$ & 9.6 \\
\hline$C s-137$ & $6.4 E+03$ & $9.4 E+03$ & $6.05+04$ & $6.2 E+03$ & $1.6 E+04$ & $6.6 E+03$ & $6.3 E+03$ & $5.4 E+0 \quad 3$ & $9.2 E+03$ & 3. $3 E+04$ \\
\hline Eu-152 & $<1$ & $<1$ & $<1$ & $<1$ & 3.3 & $<1$ & $<1$ & $<1$ & 66 & $<1$ \\
\hline Eu-154 & $<1$ & $<1$ & $<1$ & $<1$ & $<1$ & $<1$ & $<1$ & $<1$ & 1.8 & $<1$ \\
\hline Eu-155 & $<1$ & $<1$ & $<1$ & $<1$ & $<1$ & $<1$ & $<1$ & $<1$ & $<1$ & $<1$ \\
\hline$U$-rat & $<1$ & $<1$ & 8.3 & $<1$ & $<1$ & $<1$ & $<1$ & $<1$ & 6.3 & $<1$ \\
\hline $\mathrm{Th}$-nat & 1.5 & 1.5 & 6.8 & 1.5 & 1.5 & $<1$ & $<1$ & 1.5 & 65 & 11 \\
\hline$U-233^{b}$ & & & 367 & & & & & & 158 & 2.4 \\
\hline$U-238 b$ & & & 6.8 & & & & & & & \\
\hline Pu-238b & & & 1.5 & & & & & & 26.1 & 3.8 \\
\hline Fu-239b & & & 416 & & & & & & $2.6 \mathrm{E}+03$ & 250 \\
\hline$A=241^{b}$ & & & 29 & & & & & & 498 & 74.1 \\
\hline$C a r-244 b$ & & & & & & & & & 23.7 & $<1$ \\
\hline $\begin{array}{l}\text { Alpha as } \\
\text { Pu-239 }\end{array}$ & 2. $1 E+02$ & $8,3 E+01$ & 4. $3 E+04$ & $4,2 E+01$ & $1.8 E+03$ & 4. $7 E+02$ & $3.3 E+02$ & 4. $2 E+01$ & $8.9 E+04$ & $3.4 E+03$ \\
\hline
\end{tabular}

Cesium-134 and 106 Ru have inventory 11mits of $>1 E+12 \mathrm{Ci}$ and are not shown.

bianks indicate that no analytical data are availeble.

\section{B. Class L-2}

\begin{tabular}{|c|c|c|c|c|c|c|c|c|c|c|}
\hline Const ituent & N24 & w25 & W26 & W27 & W28 & W29 & W30 & $\sqrt{31}$ & W21 & W23 \\
\hline$C \cdot 14$ & 110 & 44 & 17 & 24 & 22 & $<1$ & $<1$ & 15 & $<1$ & 8.5 \\
\hline Sr.90 & $<1$ & $<1$ & $<1$ & $<1$ & 1.6 & $<1$ & $<1$ & $<1$ & $<1$ & $<1$ \\
\hline Cs- 137 & $<1$ & $<1$ & $<1$ & $<1$ & $<1$ & $<1$ & $<1$ & $<1$ & $<1$ & $<1$ \\
\hline$U \cdot$ nat & $<1$ & $<1$ & 10 & $<1$ & $<9$ & $<1$ & $<1$ & $<1$ & 7.0 & $<1$ \\
\hline$U \cdot 233^{b}$ & & & 820 & & & & & & 349 & 5.3 \\
\hline$U \cdot 238^{b}$ & & & 7.5 & & & & & & & \\
\hline Pu. $238^{b}$ & & & 21 & & & & & & 360 & 5.7 \\
\hline Pu-239b & & & 700 & & & & & & $4.4 E+03$ & 420 \\
\hline$A m-241^{b}$ & & & $<1$ & & & & & & 2.5 & $<1$ \\
\hline $\mathrm{Cm}-244^{\mathrm{b}}$ & & & & & & & & & 112 & $<1$ \\
\hline $\begin{array}{l}\text { Alpha ats } \\
\text { Pu-239 }\end{array}$ & 360 & 140 & $7.3 E+04$ & 71 & $3.0 E+03$ & 710 & 560 & 71 & $1.5+E 05$ & $5.8 E+03$ \\
\hline
\end{tabular}


For those tanks for which no analysis is given for the alpha isotopes, the worst case would be for all the alpha to be present as ${ }^{239} \mathrm{Pu}$ (for which the limits are very low). If the alpha is assumed to be ${ }^{239} \mathrm{Pu}$, then DFs of 42 to 420 are required. This may not be a poor assumption because the ${ }^{239} \mathrm{Pu}$ present in tanks $\mathrm{W}-26, \mathrm{~W}-21$, and $\mathrm{W}-23$ requires the highest DFs, within an order of magnitude of the assumption of all alpha being ${ }^{29} \mathrm{Pu} . \mathrm{A}$ more-detailed isotopic analysis of the gross alpha will be required for the remaining tanks to give a breakdown of the isotopes present and determine what treatment is required.

NUS Class L-II requires decontamination for ${ }^{14} \mathrm{C}$ and for alpha. If the uranium present is again assumed to be ${ }^{238} \mathrm{U}$, then tanks W-26 and W-21 need DFs for that radionuclide. Tanks $\mathrm{W}-26, \mathrm{~W}-21$, and $\mathrm{W}-23$ require alpha removal for ${ }^{233} \mathrm{U},{ }^{238} \mathrm{Pu},{ }^{239} \mathrm{Pu}$, and ${ }^{244} \mathrm{Cm}$. If the gross alpha is assumed to be ${ }^{239} \mathrm{Pu}$, as above, DFs of 71 to $10^{5}$ would be required to meet the L-II limits. The inventory limits for Class L- $I$ are $21 \times 10^{12}$ for ${ }^{3} \mathrm{H}$, ${ }^{60} \mathrm{Co},{ }^{106} \mathrm{Ru},{ }^{134} \mathrm{Cs},{ }^{152} \mathrm{Eu},{ }^{154} \mathrm{Eu},{ }^{155} \mathrm{Eu},{ }^{252} \mathrm{Th}$, and ${ }^{242} \mathrm{Cm}$. Also, ${ }^{137} \mathrm{Cs}$ and ${ }^{90} \mathrm{Sr}$ levels are low enough that only W-28 requires any DF for ${ }^{90} \mathrm{Sr}$.

Additional calculations were made to determine the radioactivity that would be contained in the solid product from the treatment processes if the supernate were incorporated into cement grout at a supernate:resulting concrete ratio of $1: 1.3$. The results of these calculations are shown in Table 16. The contributions of the various isotopic constituents are shown for each tank in $\mathrm{nCi} / \mathrm{L}$. Values for the solid, in $\mathrm{nCi} / \mathrm{g}$ for each constituent, are calculated based on a concrete density of $2 \mathrm{~g} / \mathrm{cm}^{3}$. Based on the results in the table, this concrete would be above NUS Class L-I for ${ }^{137} \mathrm{Cs}$ and ${ }^{90} \mathrm{Sr}$ for all tanks. It would also be above the gross alpha limits for NUS Classes L-I and L-II if all of the alpha is assumed to be ${ }^{239} \mathrm{Pu}$.

Total alpha-, beta-, and gamma-emitting radioactive contents for a drum of the solidified supernate are shown in Table 17. The nitrate content of a drum of solidified supernate was also calculated, based on the supernate nitrate concentration and ranged from 41.7 to $77.06 \mathrm{~kg} / \mathrm{drum}$, or about 10 to $19 \%$ of the mass in the drum. Only W-21 and $\mathrm{W}-26$ have a gross alpha content above $10 \mathrm{nCi} / \mathrm{g}$, making the waste from these tanks fall under NRC Class C criteria. None of the supernates has a TRU content sufficient to be classified as TRU waste, according to the WAC of the WIPP (>100 nCi/g). 
Table 16. Radiation content when untreated supernate is solidified in concrete

\begin{tabular}{|c|c|c|c|c|c|c|c|c|c|c|}
\hline $\begin{array}{r}\text { Constituont } \\
\text { (units) } \\
\end{array}$ & W24 & W25 & W26 & W27 & W28 & W29 & W30 & W31 & W21 & k23 \\
\hline $\begin{aligned}-3 & \left(n C_{1} / L\right) \\
& \left(n C_{1} / 8\right)^{b}\end{aligned}$ & $\begin{array}{r}6400^{C} \\
3.2\end{array}$ & $\begin{array}{r}7170 \\
3.6\end{array}$ & $\begin{array}{r}1.3 E+04 \\
6.4\end{array}$ & $\begin{array}{r}4340 \\
2.2\end{array}$ & $\begin{array}{r}2470 \\
1.2\end{array}$ & $\begin{array}{r}3240 \\
1.6\end{array}$ & $\begin{array}{r}4170 \\
2.1\end{array}$ & $\begin{array}{r}4200 \\
2.1\end{array}$ & $\begin{array}{r}7270 \\
3.6\end{array}$ & $\begin{array}{r}2470 \\
1.2\end{array}$ \\
\hline$c-14$ & $\frac{1.68+04 d}{8.2}$ & $\frac{6831}{3.4}$ & $\frac{2550}{1.3}$ & $\frac{3760}{1.9}$ & $\frac{3470}{1.7}$ & $\frac{2330}{1.2}$ & $\frac{1880}{0.8}$ & $\frac{1830}{0.9}$ & $\frac{21}{0.01}$ & $\frac{1320}{0.6}$ \\
\hline Co-60 & $\begin{array}{r}6830 \\
3.4\end{array}$ & $\begin{array}{r}3.98+04 \\
19.5\end{array}$ & $\begin{array}{c}2.5 E+05 \\
127\end{array}$ & $\begin{array}{r}6420 \\
3.2\end{array}$ & $\begin{array}{r}1.8 E+05 \\
90.6\end{array}$ & $\begin{array}{r}6.7 E+03 \\
3.4\end{array}$ & $\begin{array}{r}1.3 E+04 \\
6.5\end{array}$ & $\begin{array}{r}1.0 E+04 \\
5.1\end{array}$ & $\begin{array}{r}1.8 E+05 \\
88.3\end{array}$ & $\begin{array}{r}1.3 E+04 \\
6.4\end{array}$ \\
\hline$S_{5}-90^{\circ}$ & $\begin{array}{r}1.95+04 \\
9.5\end{array}$ & $\begin{array}{c}4.1 E+05 \\
203\end{array}$ & $\begin{array}{r}1.05+04 \\
5.1\end{array}$ & $\begin{array}{c}1.25+06 \\
578\end{array}$ & $\frac{3.65+06}{1820}$ & $\begin{array}{c}1.5 E+06 \\
766\end{array}$ & $\begin{array}{r}1.58+05 \\
73.5\end{array}$ & $\begin{array}{r}1.4 E+05 \\
69.8\end{array}$ & $\begin{array}{c}1.6 E+06 \\
775\end{array}$ & $\frac{8560}{4.3}$ \\
\hline $\mathrm{Cs}-137^{\circ}$ & $\begin{array}{l}4.65+06 \\
2300\end{array}$ & $\begin{array}{c}6.8 E+06 \\
3400\end{array}$ & $\begin{array}{l}4.3 E+07 \\
2.2 E+04\end{array}$ & $\begin{array}{l}4.5 x+06 \\
2240\end{array}$ & $\begin{array}{c}1.25+07 \\
5880\end{array}$ & $\begin{array}{l}\text { 4. } 8 E+06 \\
2380\end{array}$ & $\begin{array}{c}4.68+06 \\
2270\end{array}$ & $\begin{array}{l}\text { 3. } 8 E+06 \\
1950\end{array}$ & $\begin{array}{c}6.6 E+06 \\
3310\end{array}$ & $\begin{array}{c}9.12 x+06 \\
4530\end{array}$ \\
\hline Eu-152 & $\begin{array}{r}6650 \\
3.3\end{array}$ & $\begin{array}{r}3320 \\
1.7\end{array}$ & $\begin{array}{r}4360 \\
2.2\end{array}$ & $\begin{array}{r}2280 \\
1.1\end{array}$ & $\begin{array}{r}3.51+04 \\
17.3\end{array}$ & $\begin{array}{r}1930 \\
1.0\end{array}$ & $\begin{array}{r}4360 \\
2.2\end{array}$ & $\begin{array}{r}4150 \\
2.1\end{array}$ & $\begin{array}{c}6.02+05 \\
344 .\end{array}$ & $\begin{array}{r}4360 \\
2.2\end{array}$ \\
\hline Eu-154 & $\begin{array}{r}1246 \\
0.6\end{array}$ & $\begin{array}{r}2492 \\
1.2\end{array}$ & $\begin{array}{r}4980 \\
2.5\end{array}$ & $\begin{array}{r}1368 \\
0.7\end{array}$ & $\begin{array}{r}1.5 E+04 \\
7.7\end{array}$ & $\begin{array}{r}1380 \\
0.7\end{array}$ & $\begin{array}{r}3000 \\
2.2\end{array}$ & $\begin{array}{r}2480 \\
2.1\end{array}$ & $\begin{array}{c}3.4 E+05 \\
172\end{array}$ & $\begin{array}{l}3320 \\
1.7\end{array}$ \\
\hline Eu-155 & $\begin{array}{r}8310 \\
4.2\end{array}$ & $\begin{array}{r}1.4 E+04 \\
7.2\end{array}$ & $\begin{array}{r}2.5 E+04 \\
12.5\end{array}$ & $\begin{array}{r}8310 \\
4.2\end{array}$ & $\begin{array}{r}1.9 E+04 \\
9.7\end{array}$ & 8720 & $\begin{array}{r}1.5 E+04 \\
7.5\end{array}$ & $\begin{array}{r}1.4 E+04 \\
6.7\end{array}$ & $\begin{array}{r}1.1 E+05 \\
54.0\end{array}$ & $\begin{array}{r}1.8 \mathrm{E}+04 \\
8.8\end{array}$ \\
\hline Gross alpha & $\frac{104}{0.05}$ & $\frac{42}{0.02}$ & $\frac{2.1 E+04}{10.7}$ & $\frac{21}{0.01}$ & $\frac{914}{0.5}$ & $\frac{21}{0.01}$ & $\frac{208}{0.1}$ & $\frac{208}{0.1}$ & $\frac{4.4 E+04}{22.2}$ & $\frac{1700}{0}$ \\
\hline Gross beta & $\begin{array}{l}4.8 E+06 \\
2.4 E+03\end{array}$ & $\begin{array}{l}\text { 8. } 1 E+06 \\
4.1 E+03\end{array}$ & $\begin{array}{r}4.6 E+07 \\
2.3 E+04\end{array}$ & $\begin{array}{l}6.8 E+06 \\
3.4 E+03\end{array}$ & $\begin{array}{l}2.0 E+07 \\
1.0 E+04\end{array}$ & $\begin{array}{l}7.4 E+06 \\
3.7 E+03 \\
\end{array}$ & & $\begin{array}{r}4.0 E+06 \\
2.0 E+03 \\
\end{array}$ & $\begin{array}{l}1.0 E+07 \\
5.2 E+03 \\
\end{array}$ & $\begin{array}{l}9.6 E+06 \\
4.8 E+03 \\
\end{array}$ \\
\hline
\end{tabular}

Assumes a volume increase of $1.3: 1$ upon making concrete from the supernate.

bassumes a denstty of 2.0 for concrote.

cBold numbers exceed limits for nUS Cless L-I.

dBold and underlined exceed the limits for wUS Class L-II.

-Strontium-90, Cs-137, and Eu-152 also exceed limits for LLWDDD Cless L-I; Cs-137 exceeds limits for LIWDDD Class L-II.

Table 17. Radiation content of drums when untreated supernate is solidified in concrete

\begin{tabular}{|c|c|c|c|c|c|c|c|c|c|c|}
\hline Constituent & W24 & W25 & W26 & W27 & $\begin{array}{c}\text { W28 } \\
1 / \text { drum }^{\mathrm{a}} / 2\end{array}$ & W29 & W30 & W31 & W21 & พ23 \\
\hline Alphe & $2.2 \Sigma-05$ & $8.6 E-06$ & 4. $4 E-03$ & $4.3 E-06$ & $1.9 E-04$ & $4.3 E-06$ & $4.3 E-05$ & 4. 3E-05 & 9. 3E-03 & $3.6 \mathrm{E}-04$ \\
\hline Betab & 0.98 & 1.69 & 8.5 & 1.4 & 4.2 & 1.55 & 0.89 & 0.84 & 2.16 & 2.00 \\
\hline Ganmac & 0.97 & 1.44 & 9.07 & 0.84 & 2.55 & 1.02 & 0.96 & 0.83 & 1.68 & 1.91 \\
\hline $\mathrm{NO}_{3}(\mathrm{ks} / \mathrm{drum})$ & 254.1 & 54,1 & 99.3 & 58.3 & 77.1 & 58.3 & 58.3 & 56.1 & 49.6 & 41.7 \\
\hline
\end{tabular}




\subsubsection{Solidification of Supernate to a Fused Nitrate Salt Cake or Grout}

The radionuclide contents for solidified wastes from incorporation of the supernate from the MVSTs into solid LLW nitrate waste forms are shown in Table 18. The volumes were calculated by assuming a density of $2 \mathrm{~g} / \mathrm{cm}^{3}$ for the fused salt cake. The total volume of salt was then divided by 55 gal to determine the number of 55 -gallon drums required to hold the material for disposal. Drums of this size were chosen because they were indicated as the type to be used in the Waste Handling Pilot Plant for (WHPP) packaging the RHTRU waste for shipment to WIPP. The drums would be placed into shielded shipping casks in WHPP for transfer. In the first case, no decontamination of the supernate was assumed, and the results showed TRU components (expressed as gross alpha) slightly less than the $10-\mathrm{nCi} / \mathrm{g}$ limit for classification as NRC Class $\mathrm{A}$. No gross alpha limits are given for NUS solid LLW, but if the alpha isotopes are assumed to be present as ${ }^{29} \mathrm{Pu}$, then the amount in each drum exceeds the Class L-I and L-II limits by several orders of magnitude. Carbon-14 also exceeds the proposed NUS Class L-I by four orders of magnitude and NUS Class L-II limits by two orders of magnitude.

The second case assumes that the supernate is decontaminated by using a method that removes $99.9 \%$ of the ${ }^{137} \mathrm{Cs}$ and $99 \%$ of the ${ }^{90} \mathrm{Sr}$. In this case, the proposed NUS Class L-II limits are exceeded only by alpha as ${ }^{259} \mathrm{Pu}$ and ${ }^{14} \mathrm{C}$. Class L-I limits for both ${ }^{137} \mathrm{Cs}$ and ${ }^{90} \mathrm{Sr}$ require another two orders-of-magnitude decontamination. In both cases, however, the problem remaining is the alpha as ${ }^{239} \mathrm{Pu}$ and ${ }^{14} \mathrm{C}$ contamination because no easy method of decontamination exists for the very low levels of activity present. The third case shows the solidification of the solids as a cement grout with a volume increase assumed to be $150 \%$. Decontamination of both ${ }^{14} \mathrm{C}$ and alpha is still required to meet the proposed NUS Class L-II limits.

In addition to the problem with ${ }^{14} \mathrm{C}$ removal to meet proposed NUS LLW limits, organic carbon and its reaction with nitrate at elevated temperatures have raised concerns at Hanford over the use of organic ion-exchange material for removing ${ }^{137} \mathrm{Cs}$ from LLLW solutions. $^{23}$ In order to determine whether this reaction could be a problem in the MVSTs, the ratio of organic carbon to nitrate was computed for various solidification scenarios. Investigations into the problem at Hanford ${ }^{24}$ have resulted in findings that

- dilution with inorganic salts other than nitrate increased the explosion temperature;

- increasing the ratio of nitrate to ferrocyanide beyond stoichiometry reduces explosivity;

- nitrite reacts more explosively than nitrate; and

- water, if present, increases the difficulty of initiating a reaction. 
The overall nitrate:organic carbon ratio in the MVST supernate is very much larger than stoichiometric, and the concentration of organic carbon would be increased very little by the ion-exchange removal of cesium or strontium, using potassium cobalt ferrocyanide. Thus, the chance for explosion is very low and would occur only if a concentrated portion of carbon was in contact with nitrate and was allowed to heat up to the reaction temperature. Data for the calculated organic carbon present and the calculated carbon:nitrate ratios are shown in Table 18. Any organic carbon that is present could react, and the presence of organic complexing agents could lower the temperature of explosion. ${ }^{25}$ Additional analyses of the types of carbon present will be required to rule out the possibility of an explosion during any processing of MVST supernate that would heat the salt mixture to greater than $200^{\circ} \mathrm{C}$ in the presence of organic carbon.

\subsubsection{Solidification of Sludge to \& Fused Nitrate Salt Cake or Grout}

The sludge present in the MVSTs could be solidified in a fused nitrate salt cake after it has been removed from the tanks. Speculated solidifications are shown in Table 19. The insoluble solids, as estimated from the tank analyses for minimum, maximum, and estimated insoluble masses, were assumed to be incorporated in the following types of matrixes:

- the solids obtained by drying the sludge, including the interstitial nitrates present, without additional cesium and strontium removed from the supernate;

- the solids obtained by drying the sludge, including all the interstitial nitrates present, plus incorporation of ${ }^{134} \mathrm{Cs},{ }^{137} \mathrm{Cs}$, and ${ }^{90} \mathrm{Sr}$ removed by ion exchange from the supernate;

- the minimum calculated insoluble components, plus an equal mass of sodium nitrate, plus the ${ }^{134} \mathrm{Cs}$, ${ }^{137} \mathrm{Cs}$, and ${ }^{90} \mathrm{Sr}$ removed by ion exchange from the supernate;

- the minimum insoluble components, plus two times the insoluble mass of sodium nitrate, plus the ${ }^{134} \mathrm{Cs},{ }^{137} \mathrm{Cs}$, and ${ }^{90} \mathrm{Sr}$ removed by ion exchange from the supernate;

- the maximum calculated insoluble components, plus an equal mass of sodium nitrate, plus the ${ }^{134} \mathrm{Cs}$, ${ }^{137} \mathrm{Cs}$, and ${ }^{90} \mathrm{Sr}$ removed by ion exchange from the supernate;

- the maximum insoluble components, plus two times the insoluble mass of sodium nitrate, plus the ${ }^{134} \mathrm{Cs},{ }^{137} \mathrm{Cs}$, and ${ }^{90} \mathrm{Sr}$ removed by ion exchange from the supernate;

- the estimated insoluble components, plus an equal mass of sodium nitrate, plus the ${ }^{134} \mathrm{Cs},{ }^{137} \mathrm{Cs}$, and ${ }^{90} \mathrm{Sr}$ removed by ion exchange from the supernate;

- the estimated insoluble components, plus two times the insoluble mass of sodium nitrate, plus the ${ }^{134} \mathrm{Cs},{ }^{137} \mathrm{Cs}$, and ${ }^{90} \mathrm{Sr}$ removed by ion exchange from the supernate; and

- the estimated and maximum mass of insoluble components, plus the ${ }^{134} \mathrm{Cs},{ }^{137} \mathrm{Cs}$, and ${ }^{90} \mathrm{Sr}$ removed by ion exchange from the supernate, in $150 \%$ volume of cement grout. 
The isotopic contributions to each 55 -gal drum of L.LW for ${ }^{90} \mathrm{Sr},{ }^{137} \mathrm{Cs},{ }^{14} \mathrm{C},{ }^{60} \mathrm{Co}$, Eu isotopes, and gross alpha are given for each case. The organic carbion:nitrate ratio was also calculated for each case, using nitrate salt cake, and includes organic ion exchanger added to pick up the cesium from the supernate, if that process were used, and the organic carbon from the supernate. The results are shown in Table 20. It must be pointed out that the samples of sludge reported are "point samples" from one sampling point in each tank. Therefore, they are limited in their ability to predict the composition of the sludge in the rest of the tank and, hence, do not preclude the existence of a slug of organic which could react during processing steps that concentrate the nitrate and increase the temperature of the mixture. For the solidified sludge containing the supernate cesium, about 30 to $50 \mathrm{Ci}$ of ${ }^{137} \mathrm{Cs}$ and 2000 to $4700 \mathrm{nCi} / \mathrm{g}$ of gross alpha will be present in each drum. These concentrations will ensure that the drums will be RH-TRU. The guidelines for WIPP WAC require a surface dose rate $<200 \mathrm{mrem} / \mathrm{h}$ for contact-handled waste.

\section{SUMMARY}

In this study, data are presented on the chemical species and radiochemical compositions present in the LLLW tank supernates and sludges. These data allow the calculation of the degree of decontamination required to meet various treatment/storage/disposal rules and laws. They also help determine whether liquid and solid LLW and mixed-waste acceptance criteria can be met for the various TSD facilities. Results show that ${ }^{137} \mathrm{Cs},{ }^{90} \mathrm{Sr},{ }^{60} \mathrm{Co}$, actinides, and ${ }^{14} \mathrm{C}$, plus RCRA metals and nitrate, must be removed from the supernate to meet wastewater release limits or treatment plant WAC. Actinides and ${ }^{14} \mathrm{C}$ must be removed to meet the proposed NUS Class L-1 and L-II solid LLW disposal limits. Solidified supernate, when treated separately from the sludge, does not meet the WIPP WAC. Solidified MVST sludge contains actinides at greater than $100 \mathrm{nCi} / \mathrm{g}, \mathrm{RCRA}$ metals, and gamma sources that make it a mixed, RH-TRU waste. 
Table 20. Organic carbon in solidified solids

\section{Organic carbon in MVSTs}

From KCoFeCN DX removal of cesium from supernate $161.8 \mathrm{~kg}$

From supernate solids $498.7 \mathrm{~kg}$

Total organic carbon from MVST sludge

$1387.5 \mathrm{~kg}$

Total organic carbon to be solidified

$2048.0 \mathrm{~kg}$

Ratio of organic carbon to nitrate in drums solidified in sodium nitrate salt cake from Table 19

Total sludge volume placed in drums 0.024

Low estimate with $1: 1$ insolubles to nitrate 0.048

Low estimate with $1: 2$ insolubles to nitrate 0.024

Average estimate with $1: 1$ insolubles to nitrate 0.035 Average estimate with $1: 2$ insolubles to nitrate 0.018

High estimate with $1: 1$ insolubles to nitrate 0.032 High estimate with 1:2 insolubles to nitrate 


\section{REFERENCES}

1. M. B. Sears, J. L. Botts, R. N. Ceo, J. J. Ferrada, W. H. Griest, J. M. Keller, and R. J. Schenley, Sampling and Analysis of Radioactive Liquid Wastes and Sludges in the Melton Valley and Evaporator Storage Tanks at ORNL, ORNL/TM-11652, 1990.

2. R. N. Ceo, M. B. Sears, and J. T. Shor, Physical Characterization of Radioactive Sludges in Selected Melton Valley and Evaporator Facility Storage Tanks, ORNL/TM-11653, 1990.

3. F. J. Peretz, B. R. Clark, C. B. Scott, and J. B. Berry, Characterization of Low-Level Liquid Wastes at the Oak Ridge National Laboratory, ORNL/TM-10218, 1986.

4. DOE Order 5400.5, Radiation Protection of the Public and the Environment (Feb. 8, 1990).

5. Licensing Requirements for the Land Disposal of Radioactive Waste, 10 CFR Part 61, (1983).

6. Standards for Protection Against Radiation, 10 CFR Part 20.

7. Low-Level Radioactive Waste Policy Amendments Act, Pub. L. 99-240 (January 1986).

8. J. R. Parrott, Jr., T. J. Abraham, Jr., T. E. Kent, and P. A. Taylor, ORNL Liquid Waste Treatment Systems Waste Acceptance Criteria, WM-WMCO-201, 1990.

9. Resource Conservation and Recovery Act of 1976, Pub. L. 94-580 (October 1976).

10. Identification and Listing of Hazardous Waste, 40 CFR Part 261, 1980.

11. Hazardous and Solid Waste Amendments of 1984, Pub. L. 98-616 (November 1984).

12. EPA Interim Primary Drinking Water Standards, 40 CFR Part 265, App. III (1989).

13. National Primary Drinking Water Requlations, 40 CFR Part 141, Subparts A and B (1989).

14. EPA National Secondary Drinking Water Regulations, 40 CFR Part 143.3 (1989).

15. Tennessee Water Quality Criteria - Domestic Water Supply, "Rules and Regulations of the State of Tennessee," Chap. 1200-4-3-.03(1).

16. U.S. Nuclear Regulatory Commission and U.S. Environmental Protection Agency, Guidance on the Definition and Identification of Commercial Mixed Low-Level Radioactive and Hazardous Waste and Answers to Anticipated Questions, Jan. 8, 1987. 
17. Pcikaging and Transportation of Radioactive Material, 10 CFR Part 71. (Jan. 1, 1990).

18. L. E. McNeese, J. B. Berry, G. E. Butterworth III, E. D. Collins, T. H. Monk, B. D. Patton, and J. W. Snider, Overall Strategy and Program Plan for Management of Radioactively Contaminated Liquid Wastes and Transuranic Sludges at the Oak Ridge National Laboratory, ORNL/TM-10757, 1988.

19. Nuclear Management and Resources Council, The Management of Mixed Low-Level Radioactive Waste in the Nuclear Power Industry, NUMARC/NESP-006, January 1990.

20. Hazardous and Solid Waste Amendments of 1984, 40 CFR Part 268.

21. F. C. Kornegay, The New Toxicity Characteristie, Environmental Protection Information Bulletin, The ORNL Environmental Coordinator's Office, September 1990.

22. Waste Acceptance Criteria for the Waste Isolation Pilot Plant, WIPP-DOE-069, Rev. 2, Westinghouse Electric Corporation and WIPP Technical Support Contractor, September 1985.

23. L L Burger, Complexant Stability Investigation, Task 1. Ferrocyanide Solids, PNL-5441, Pacific Northwest Laboratories, 1984.

24. L L Burger and R. D. Scheele, Interim Report Cyanide Safety Studies, Sept. 30, 1988.

25. E. C. Martin, Complexant Stability Investigation, Task 2- Organic Complexants, PNL5453, Pacific Northwest Laboratory, 1985. 
APPENDDX A

DATA FOR LULW TANKS W-21 and W-23-W-31 
Table A.1. Analytical and radiological data for LLLW tank W-21 A. Radiological Analyses

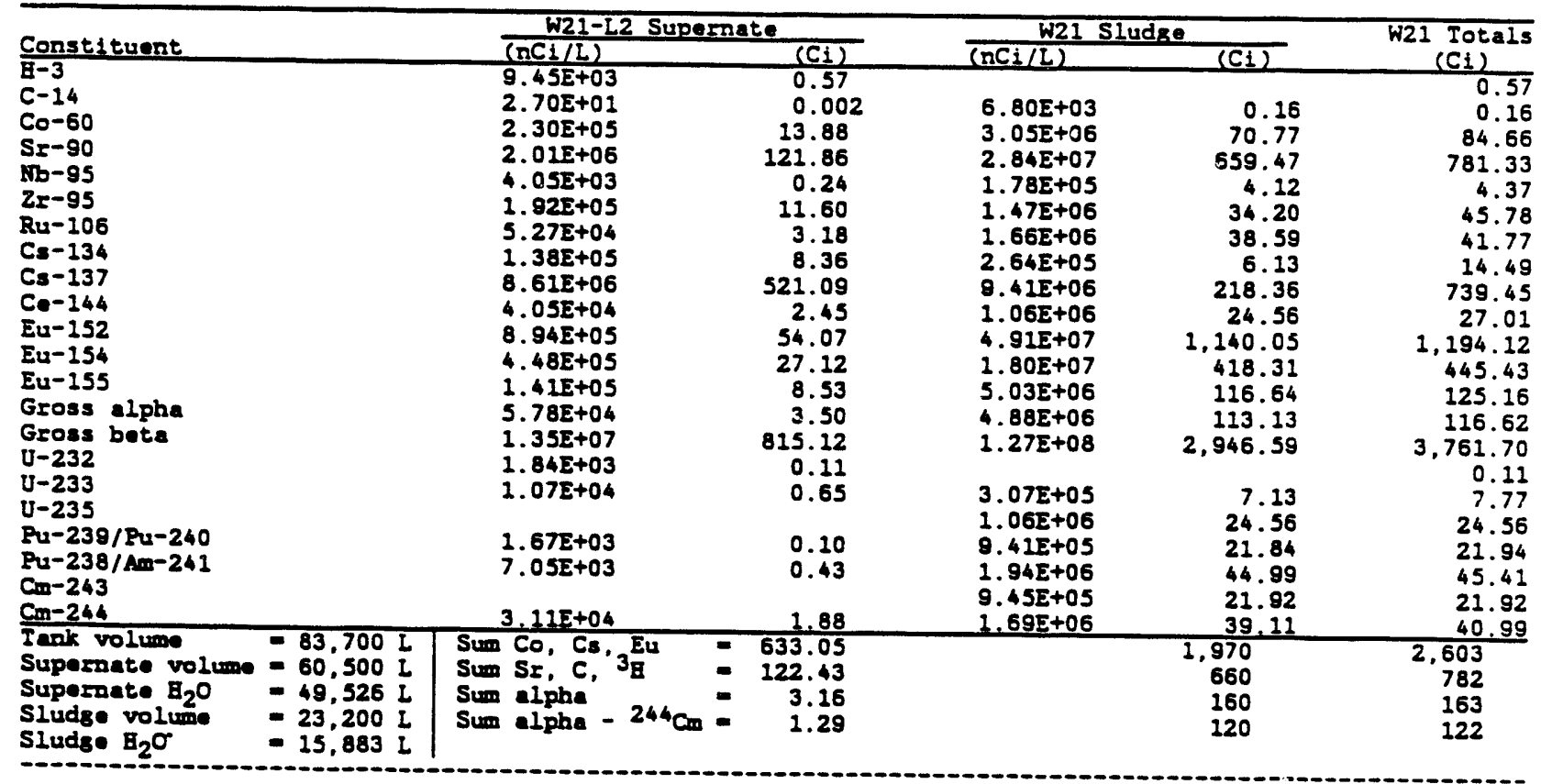

B. Fhysical/Chemical Analyses

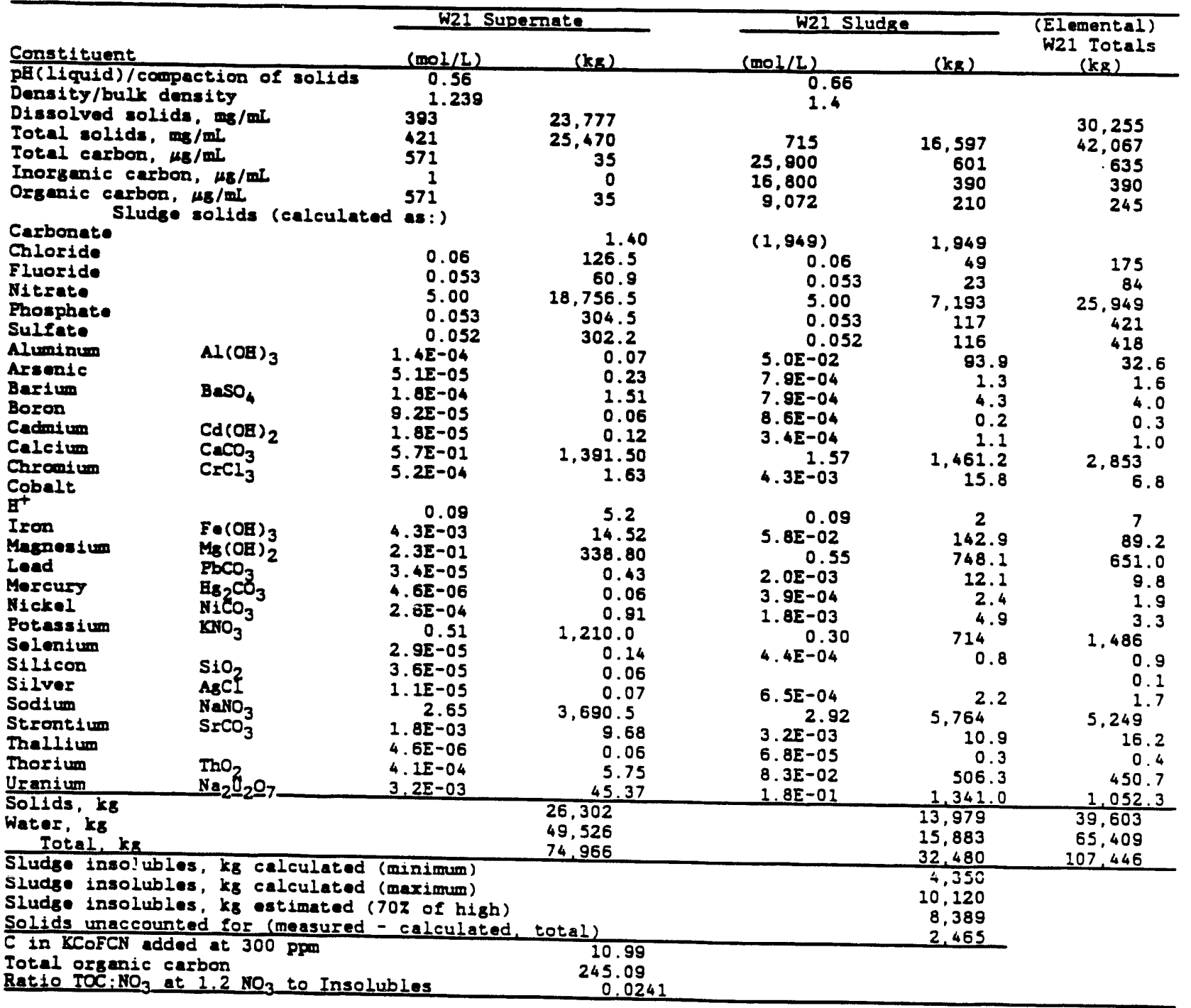


Table A.2 Analytical and radiological data for LLLW tank W-23

A. Radiological Analyses

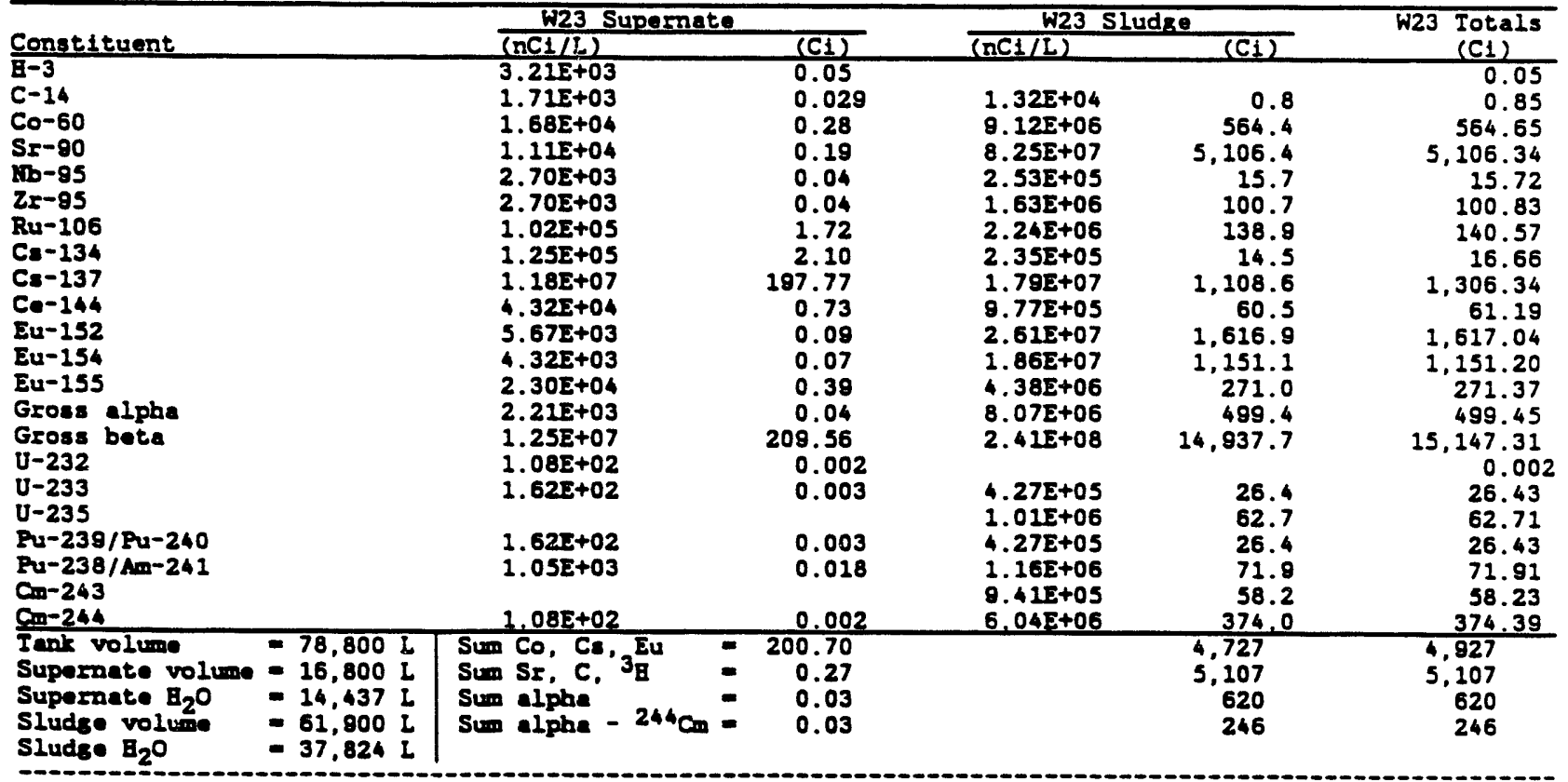

B. Fhysical/Chenteal Analyses

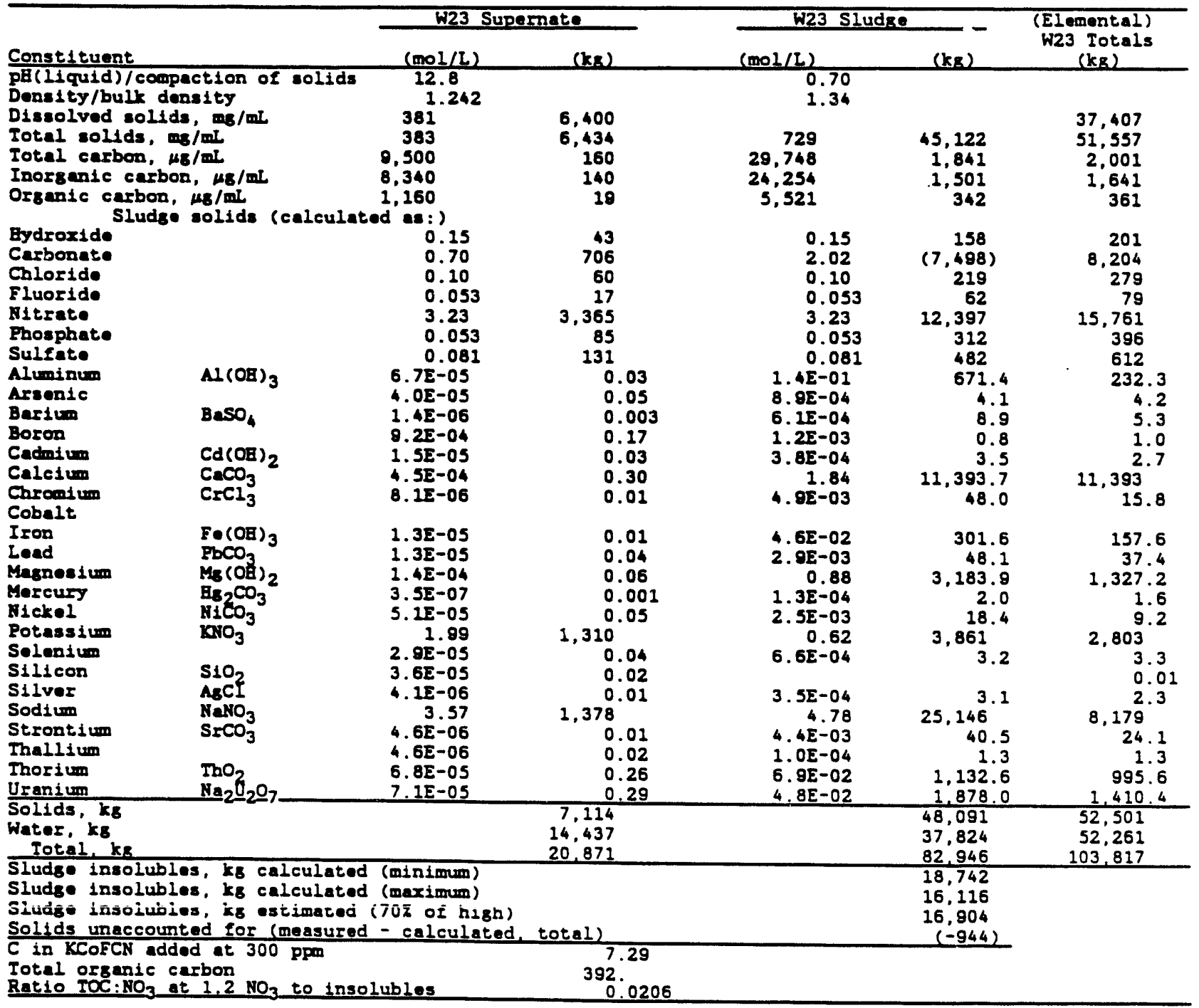


Table A3. Analytical and radiological aista for LLLW tank W-24

A. Radiological Analyses

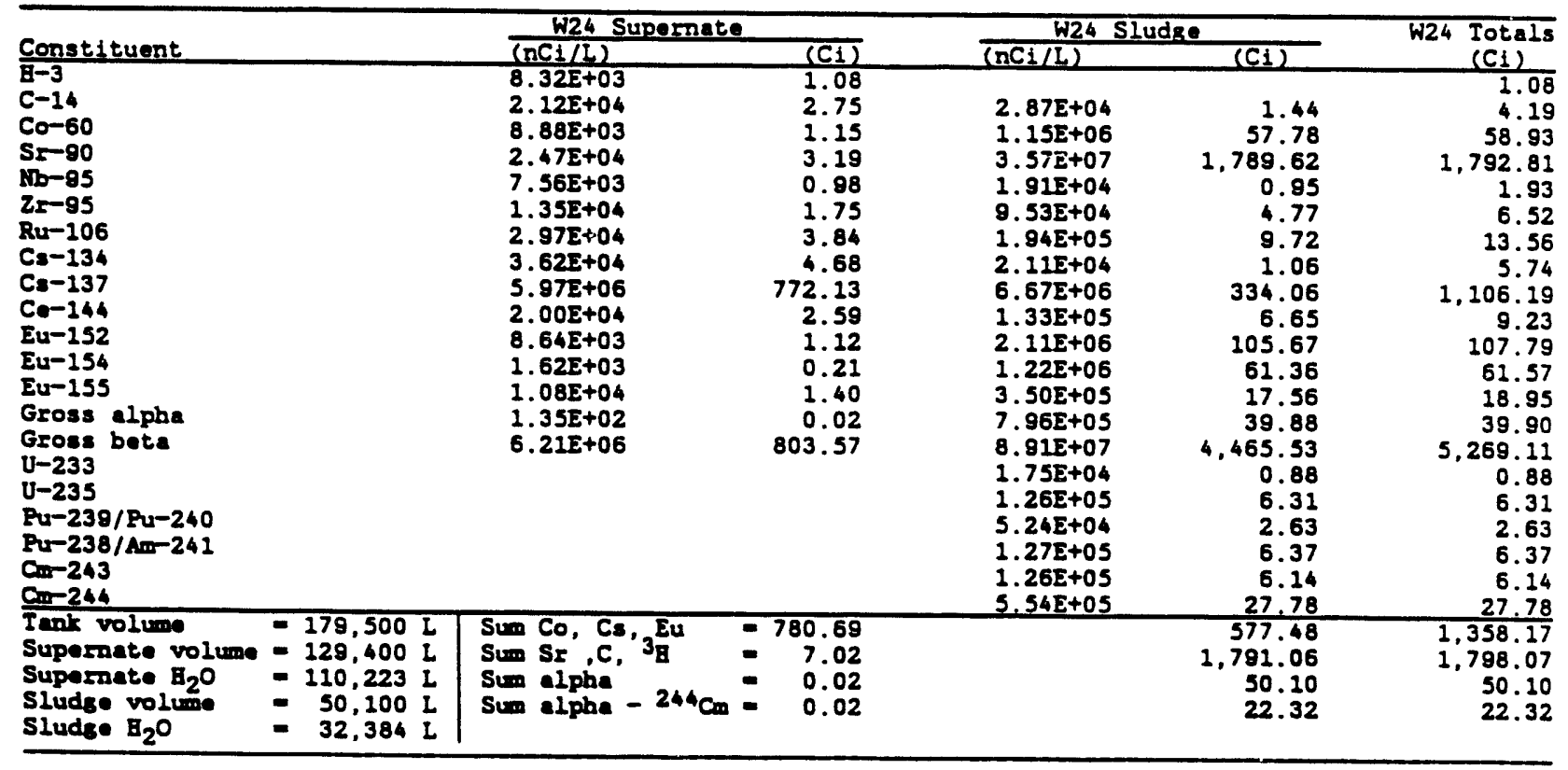

B. Fhysical/Chemical Analyses

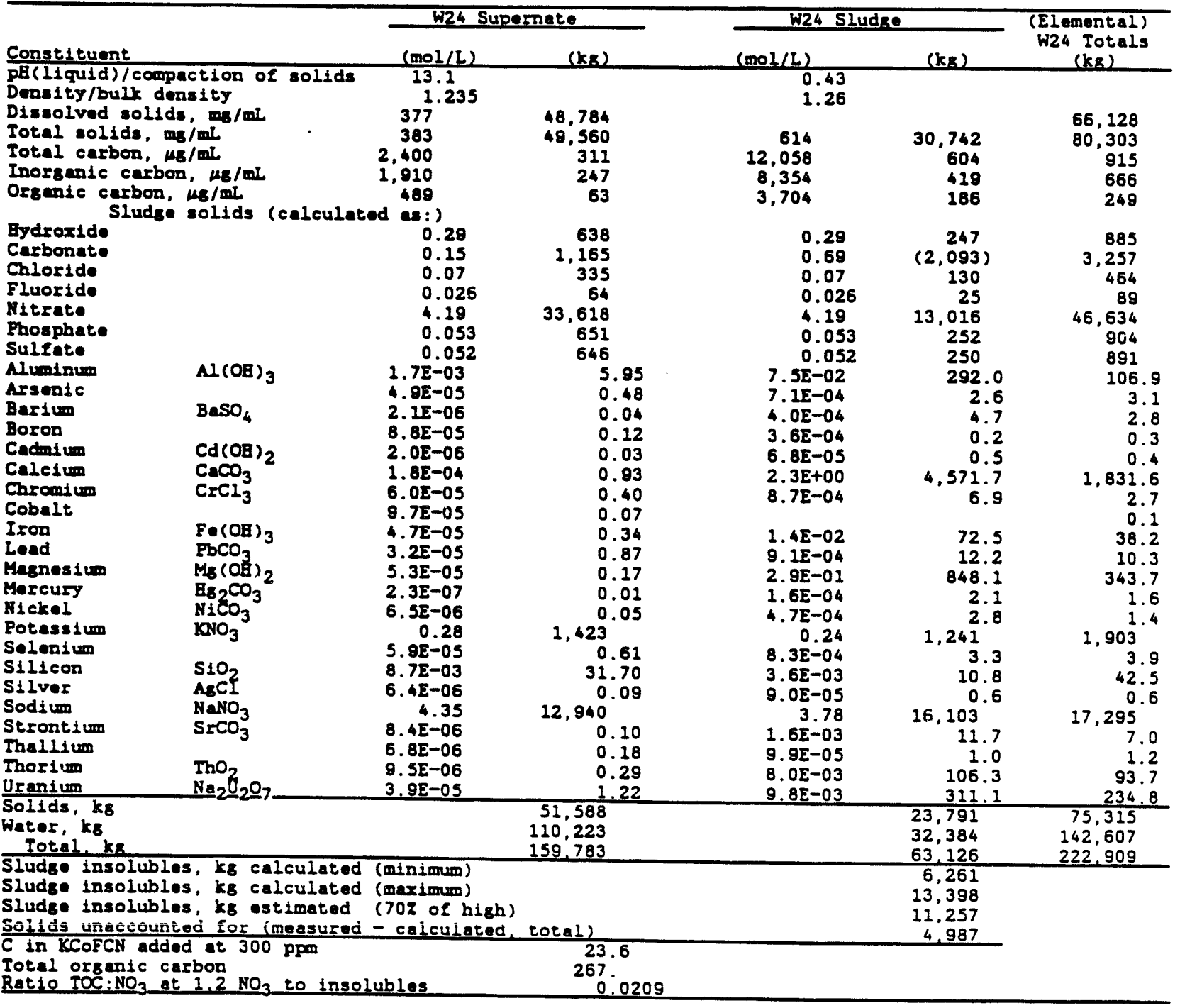


Table A4. Analytical and radiological data for LLLW tank W-25 A. Radiological Analyses

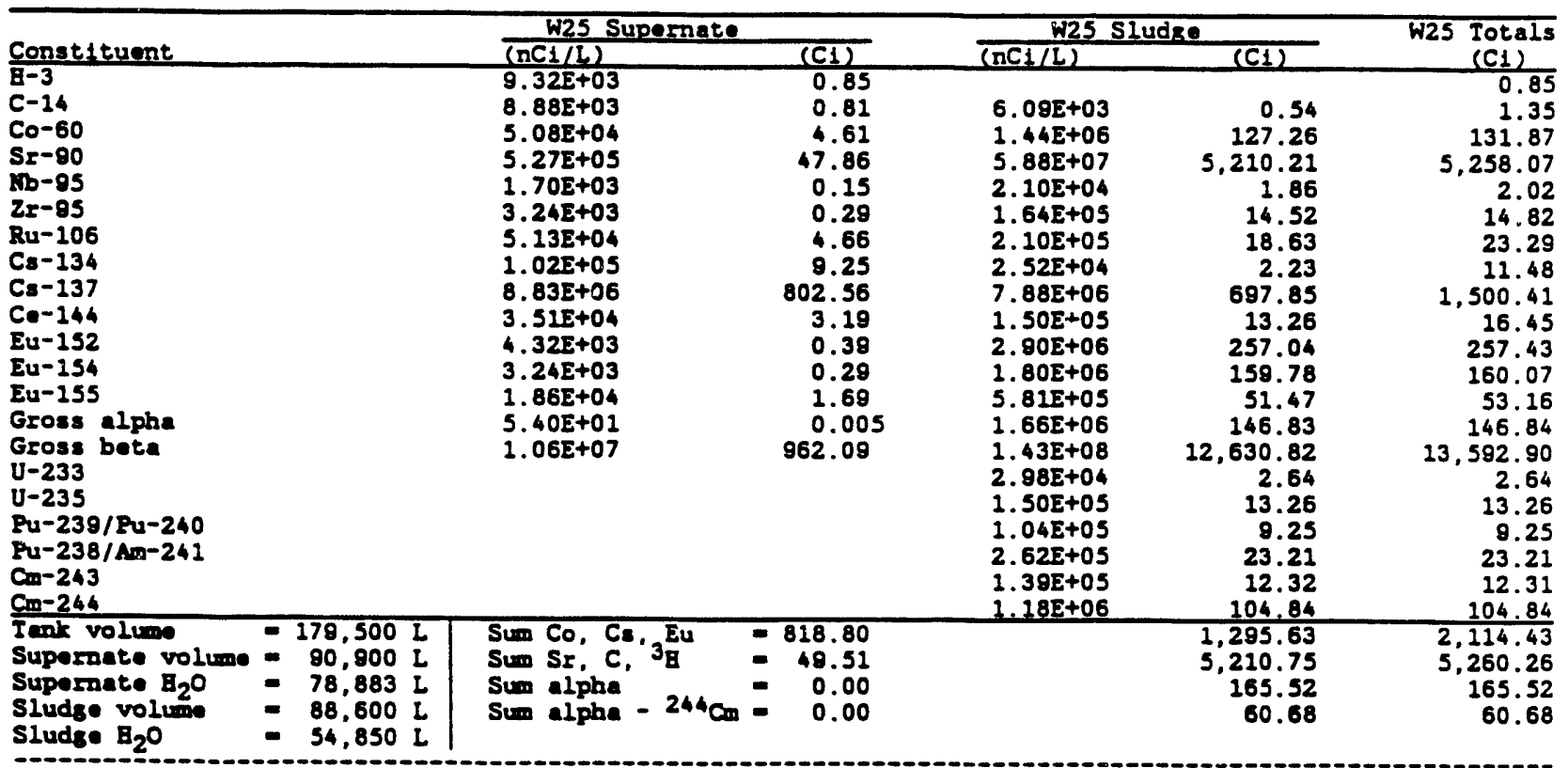

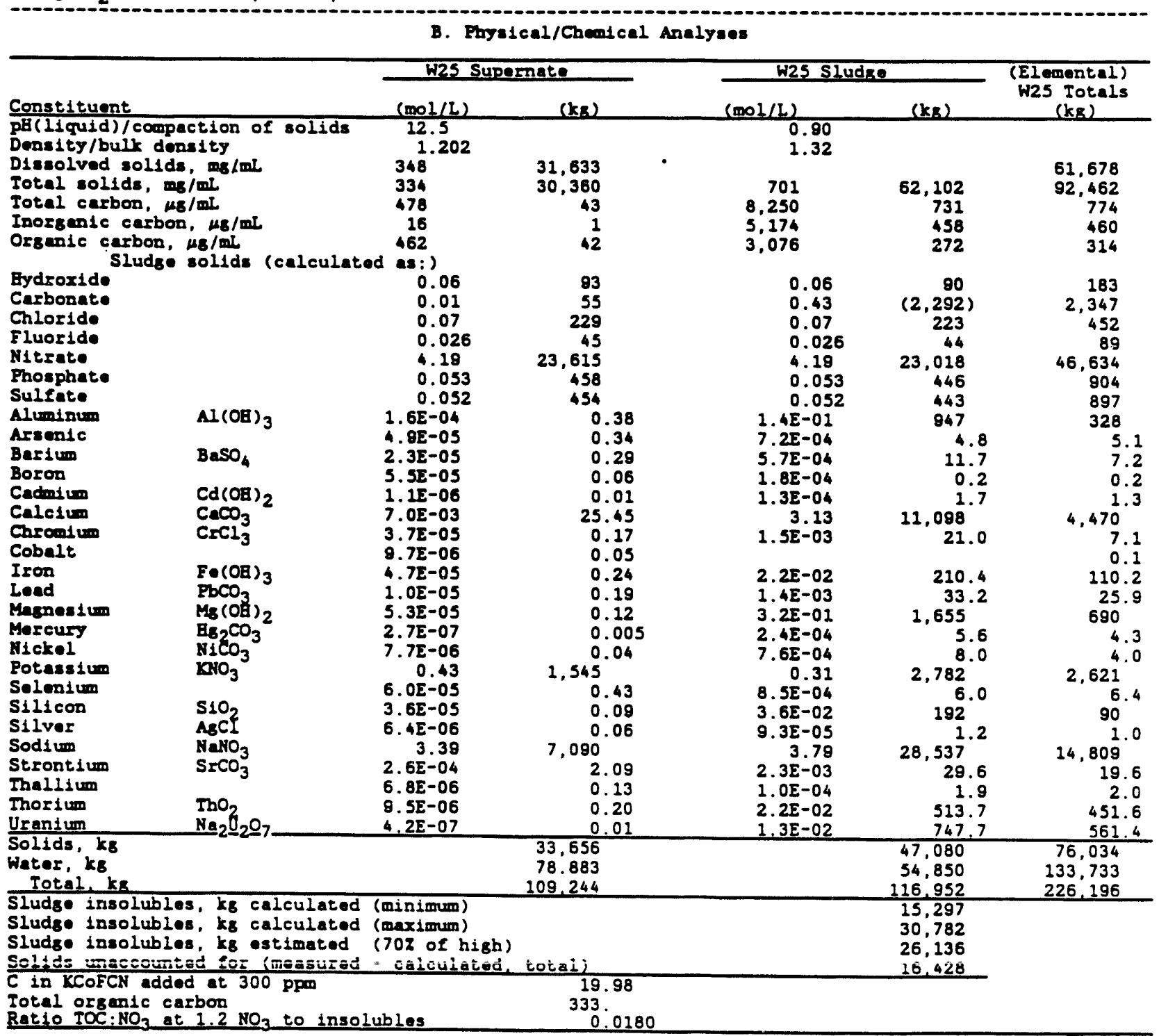


Table A.5. Analytical and radiological data for LLLW tank W-26

A. Radiological Analyses

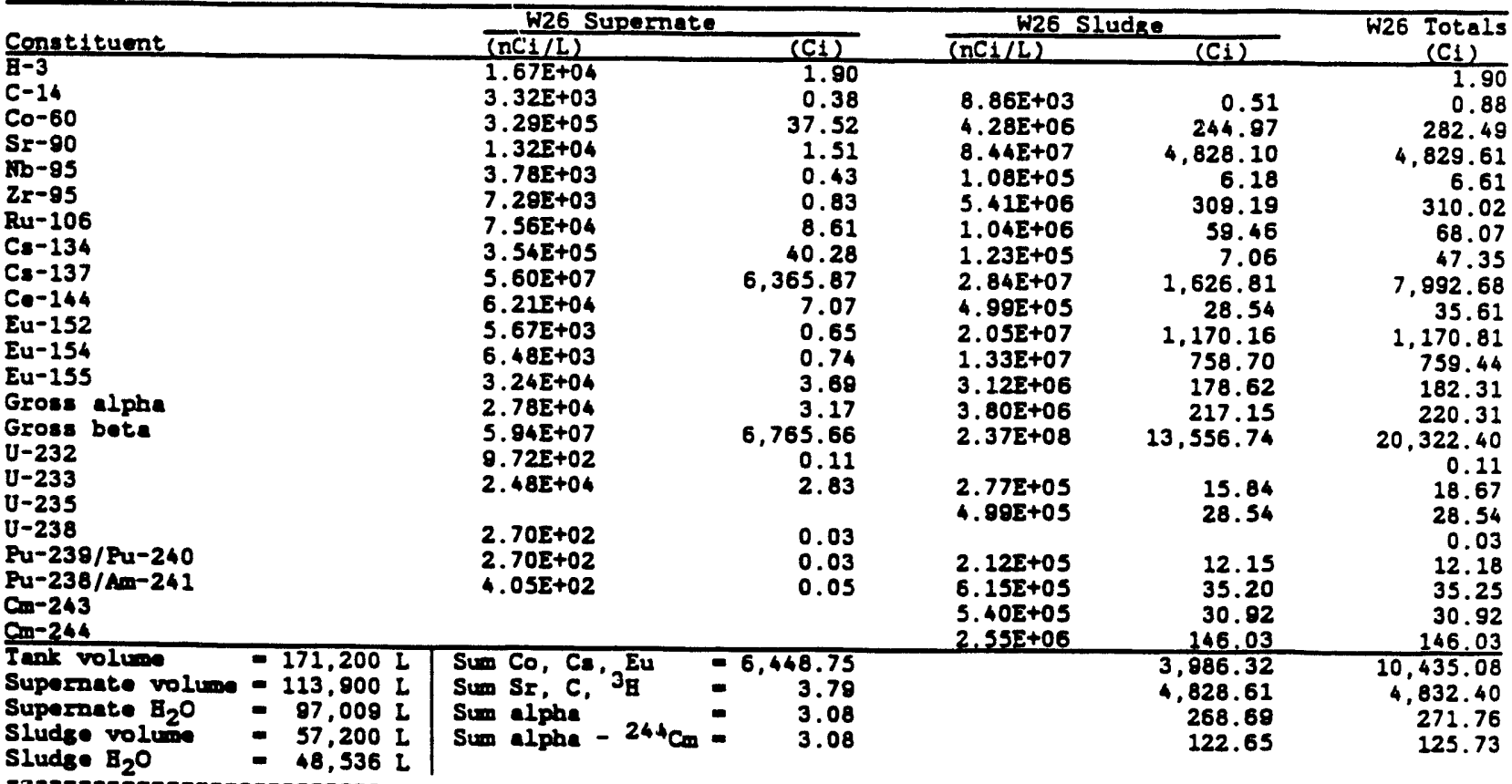

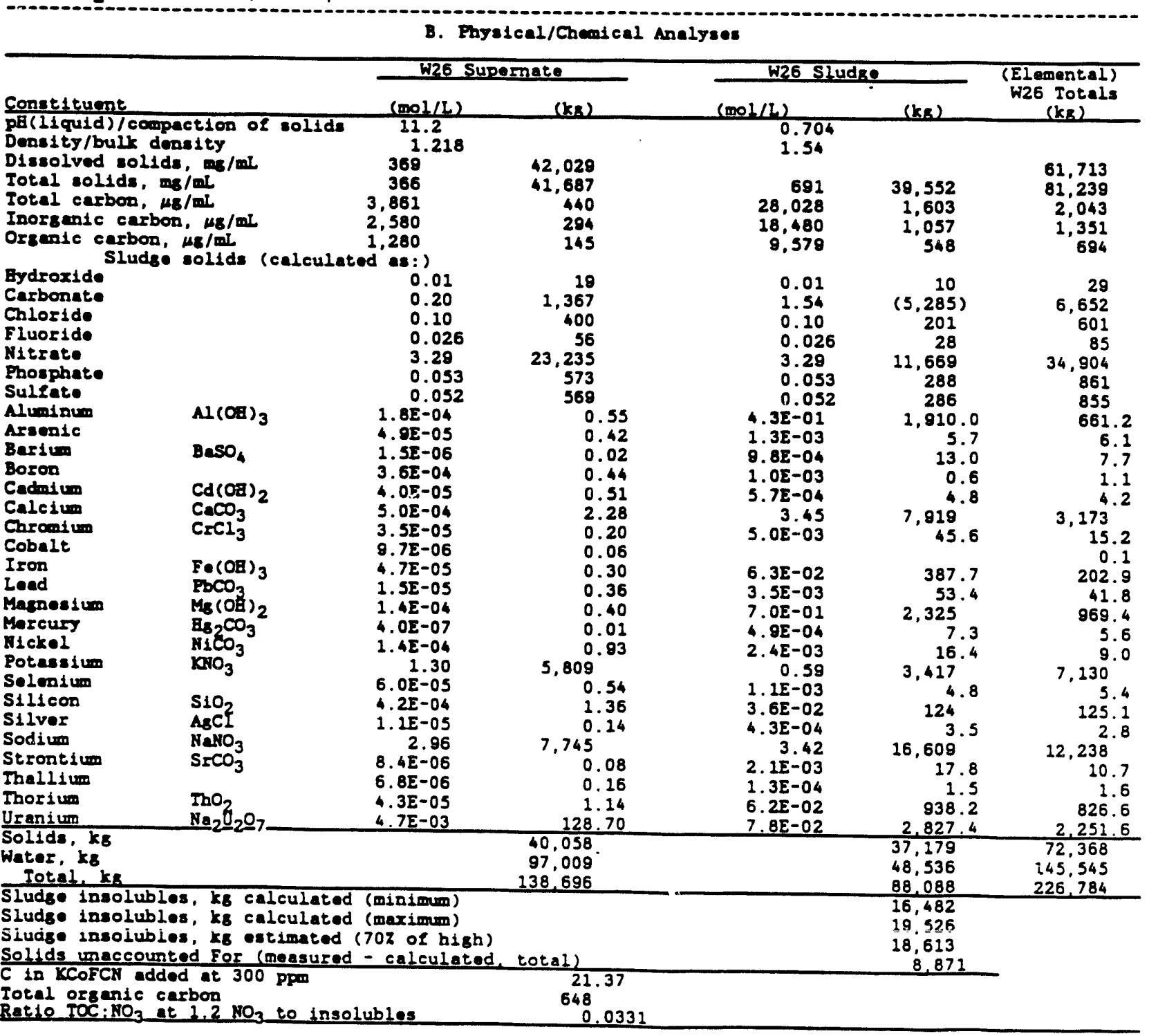


Table A6. Analytical and radiological data for LLLW tank W-27

A. Radiological Analysos

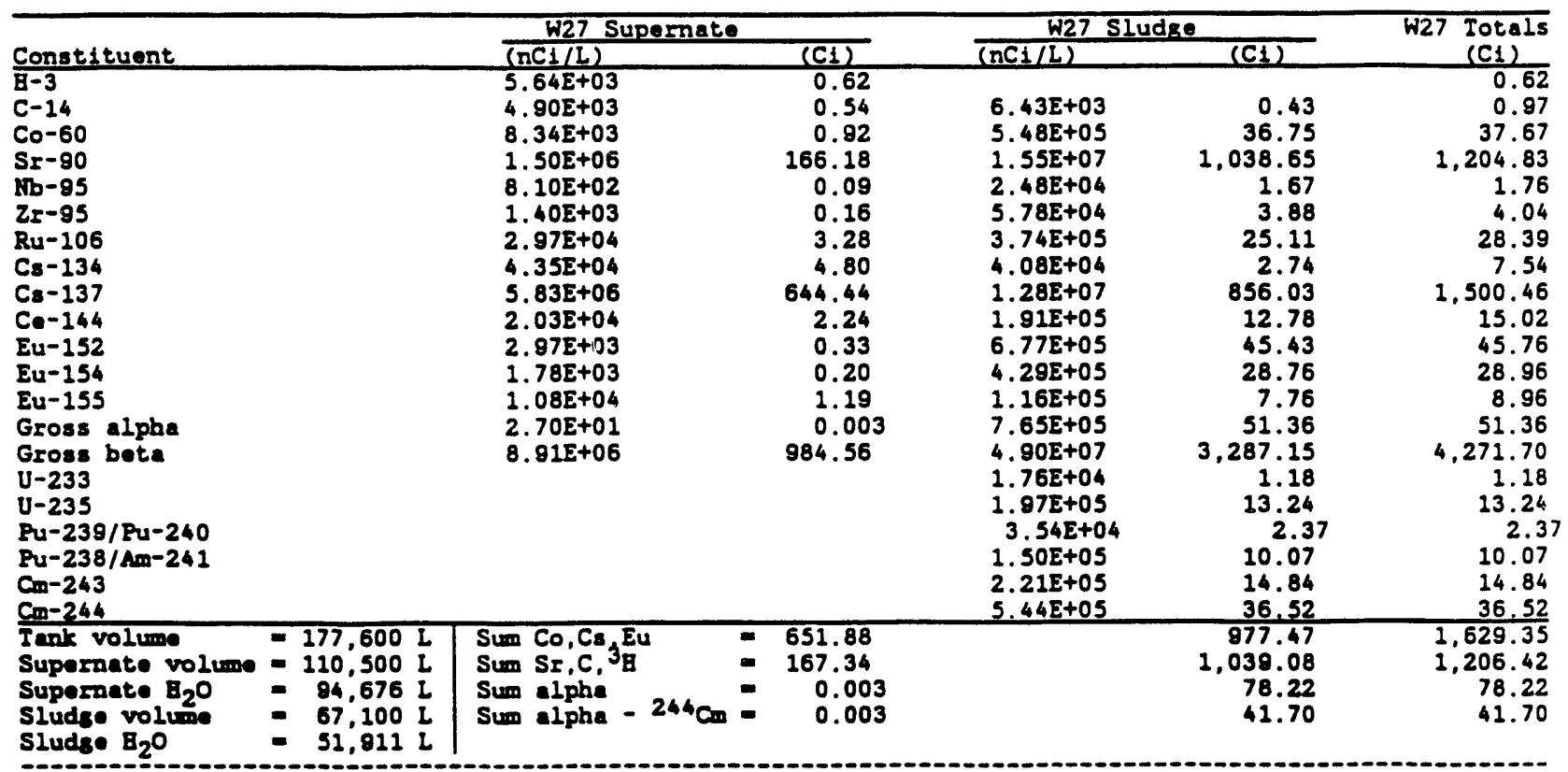

\section{B. Physical/Chemical Analyses}

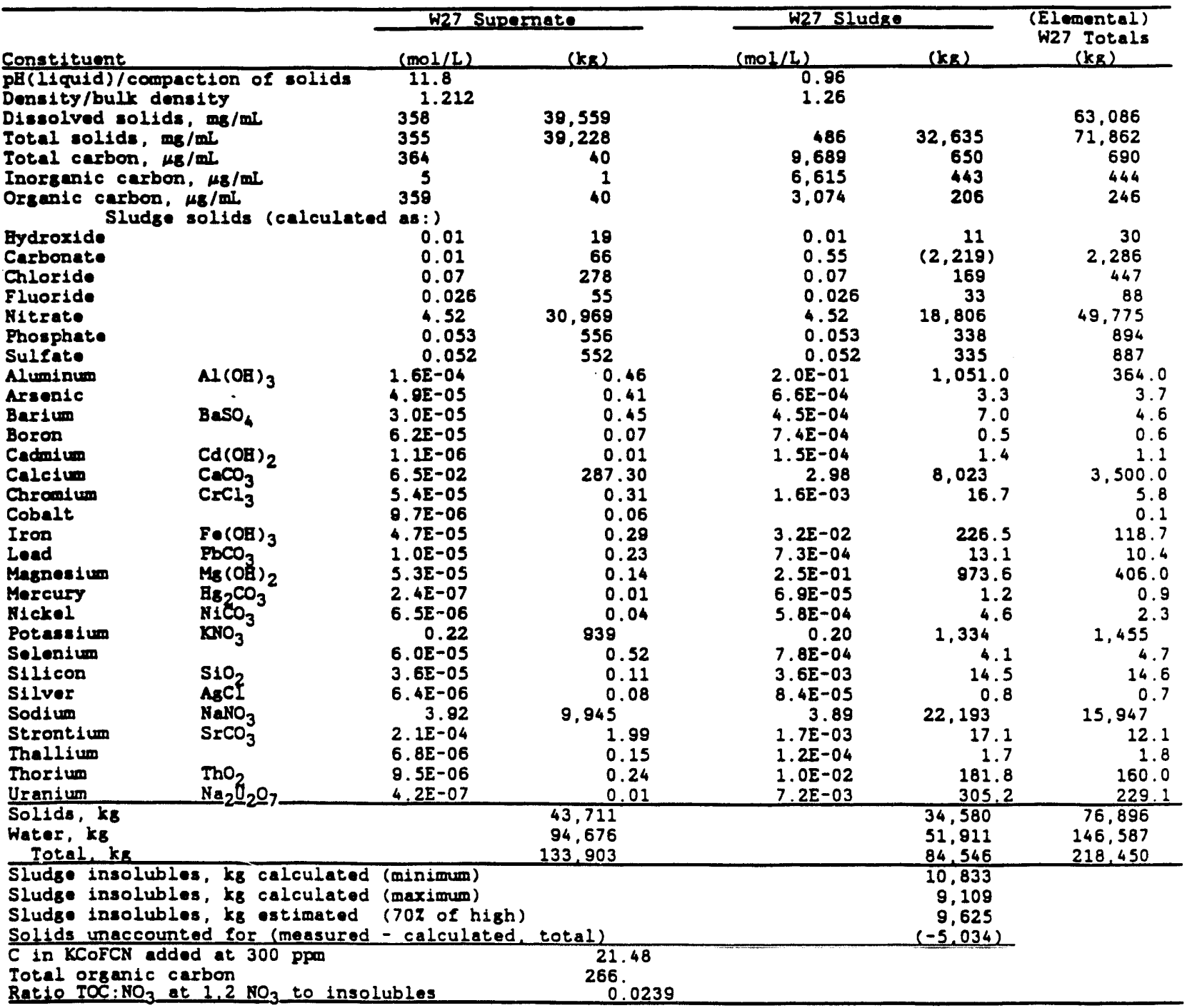


Table A.7. Analytical and radiological data for LLLW tank W-28

A. Radiological Analyses

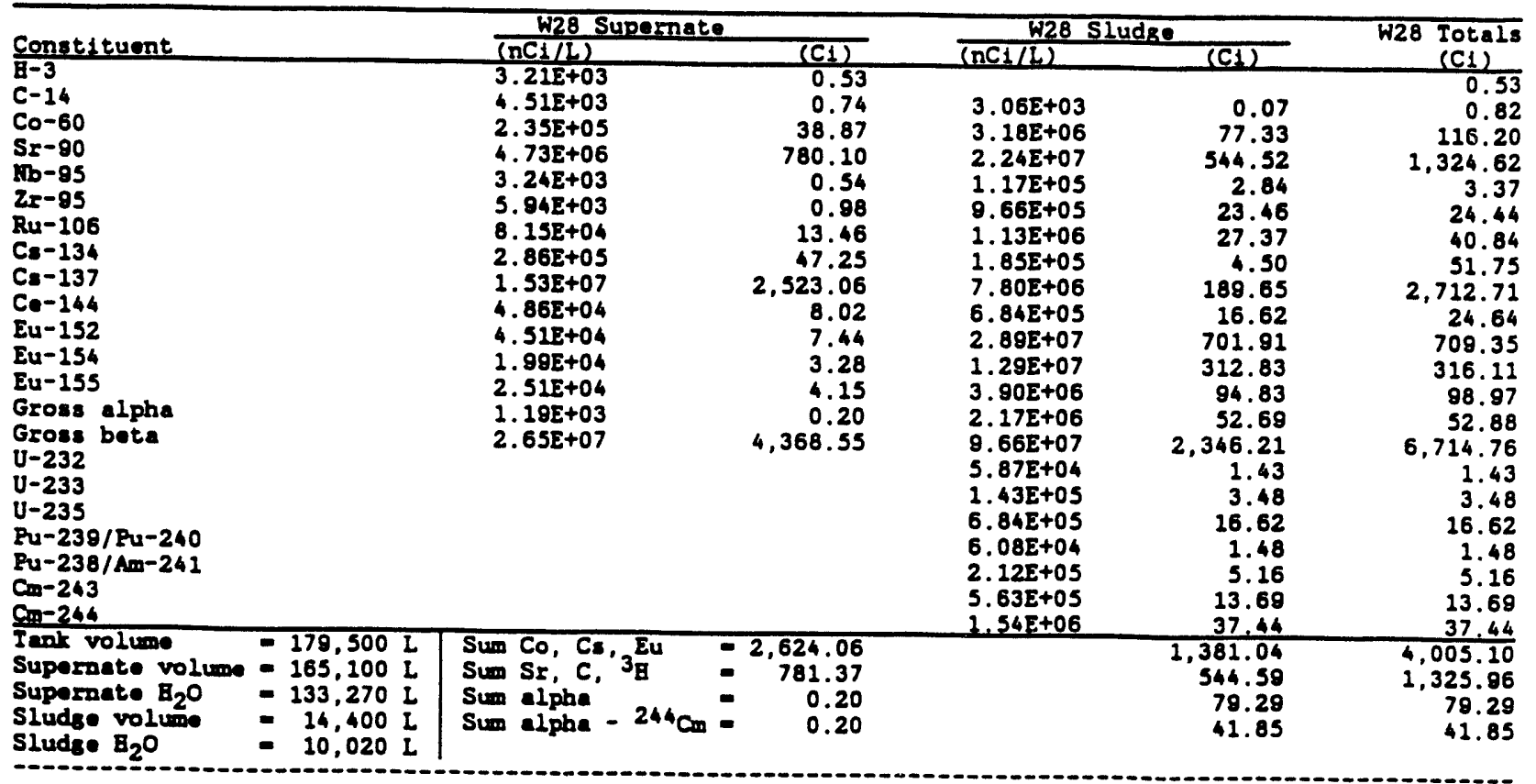

B. Physical/Chenical Analyses

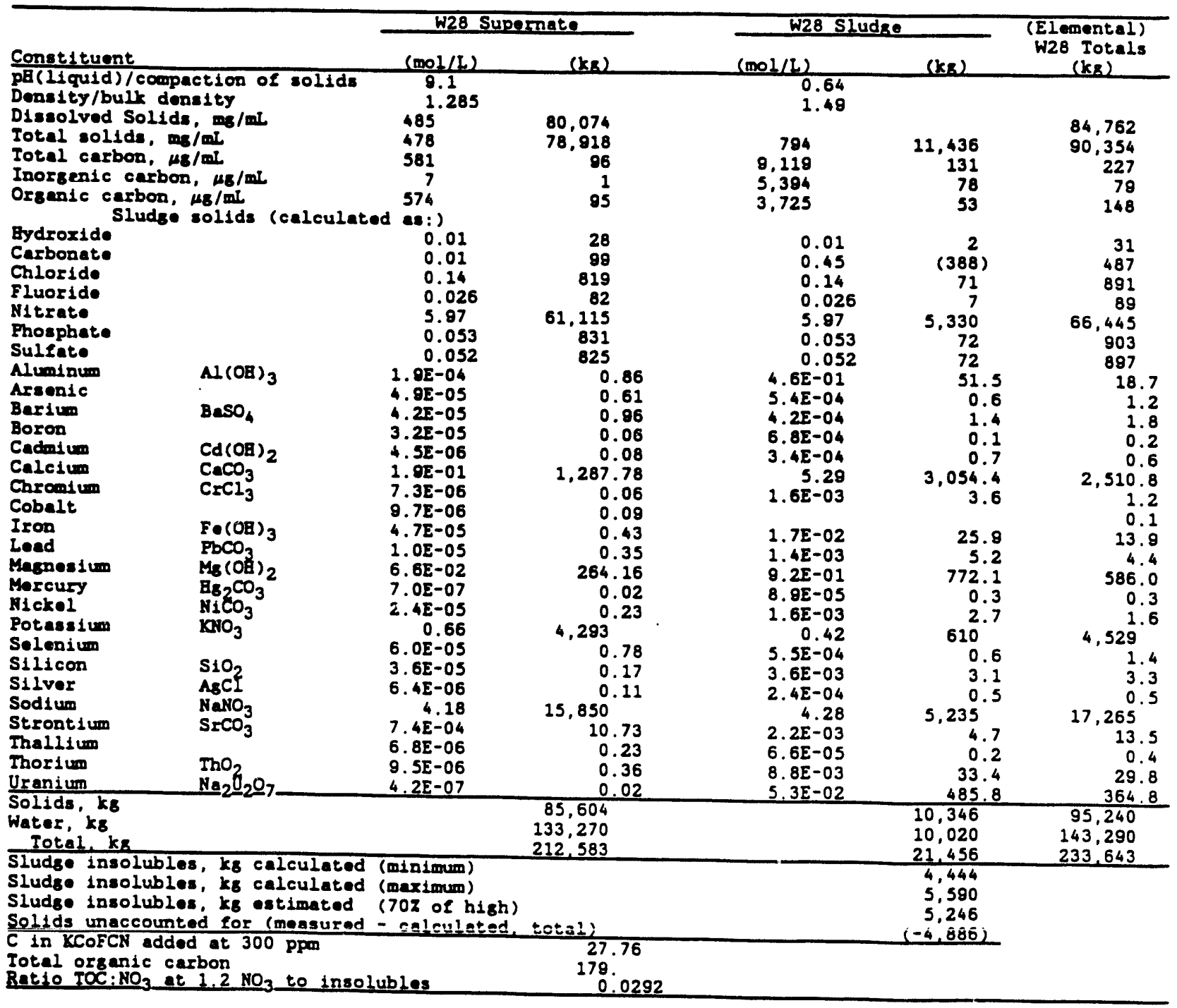


Table A.8. Anałytical and radiological data for LLLW tank W-29

A. Radiological Analysos

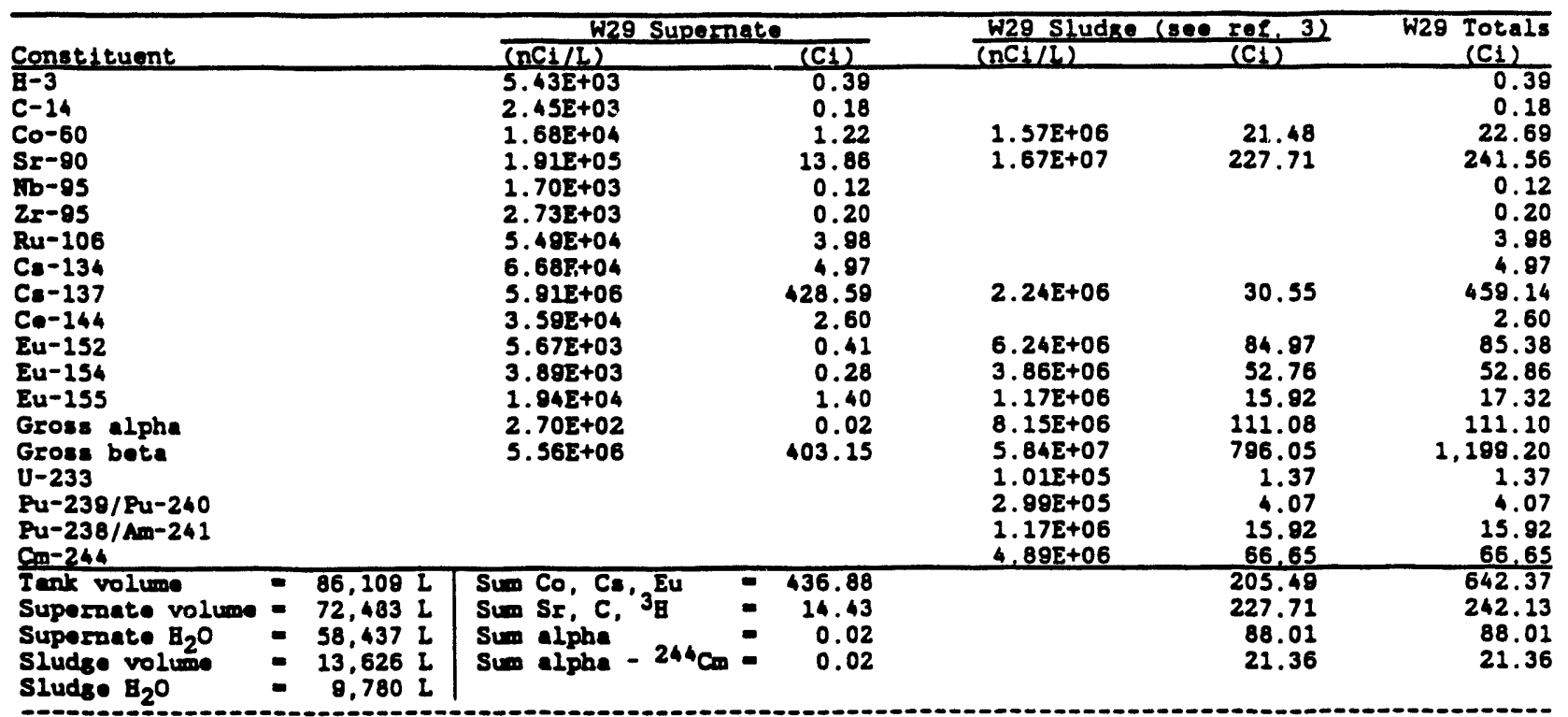

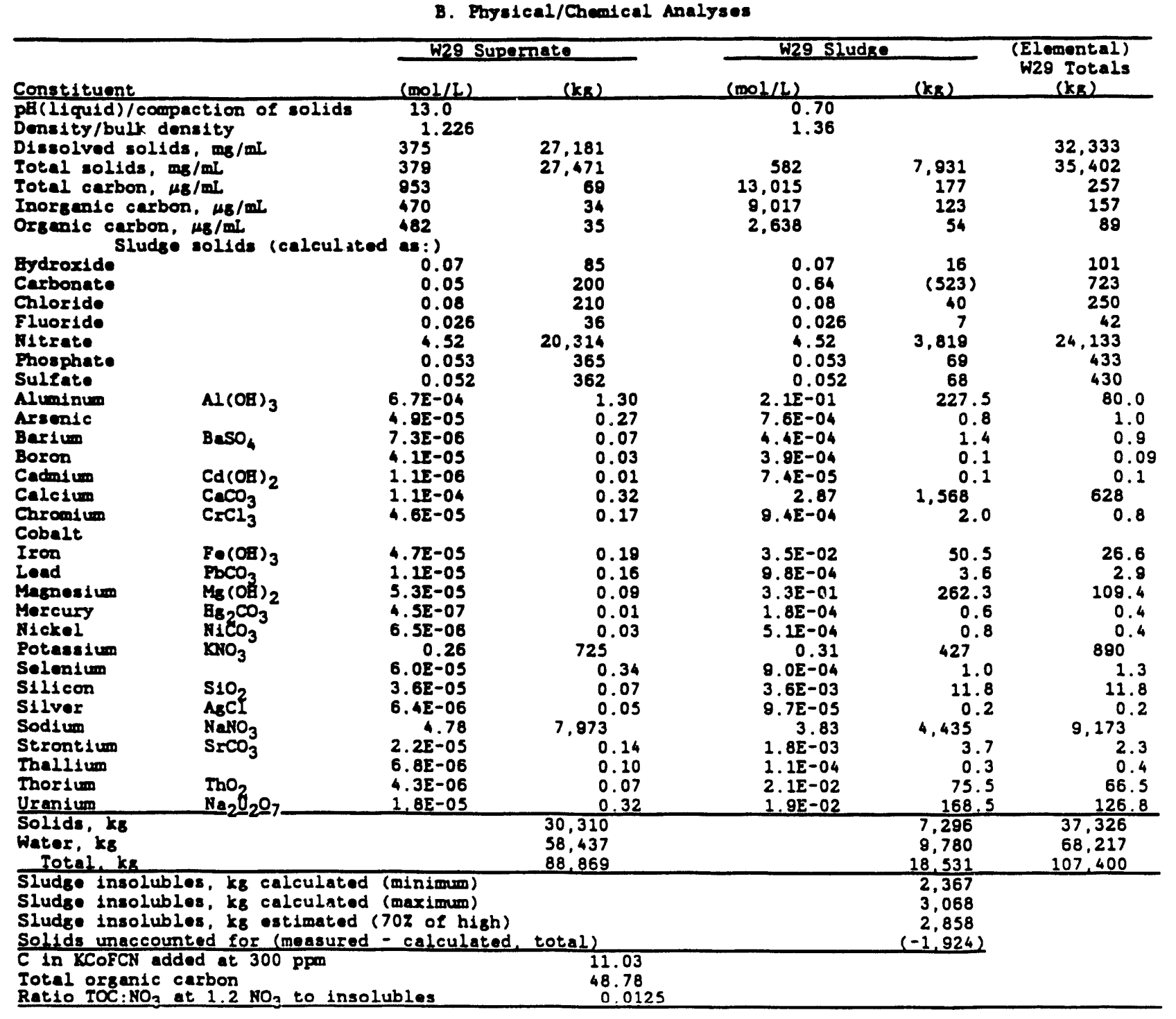


Table A.9. Analytical and radiological data for LLLW tank W-30

A. Radiological Analyses

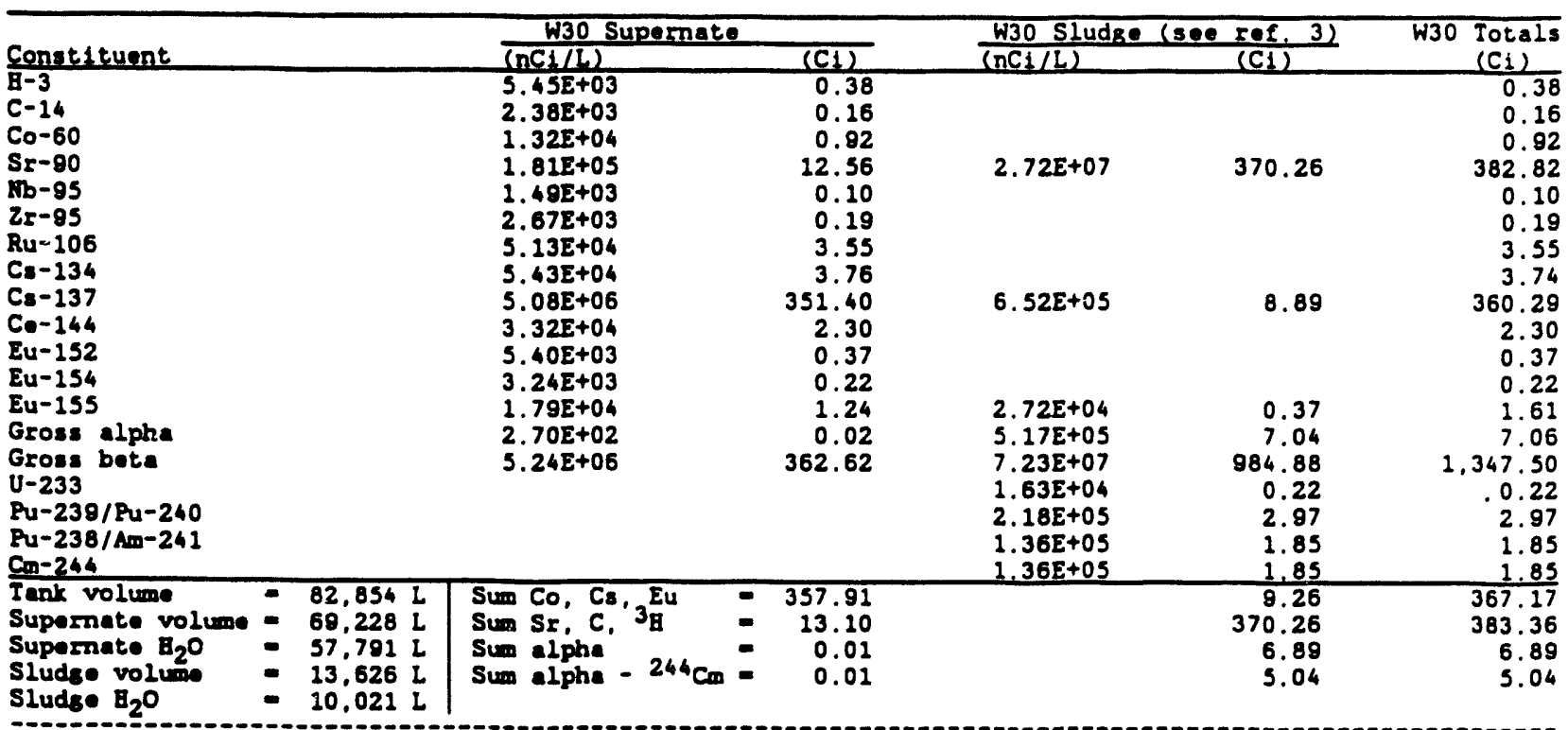

B. Physical/Chemical Analyses

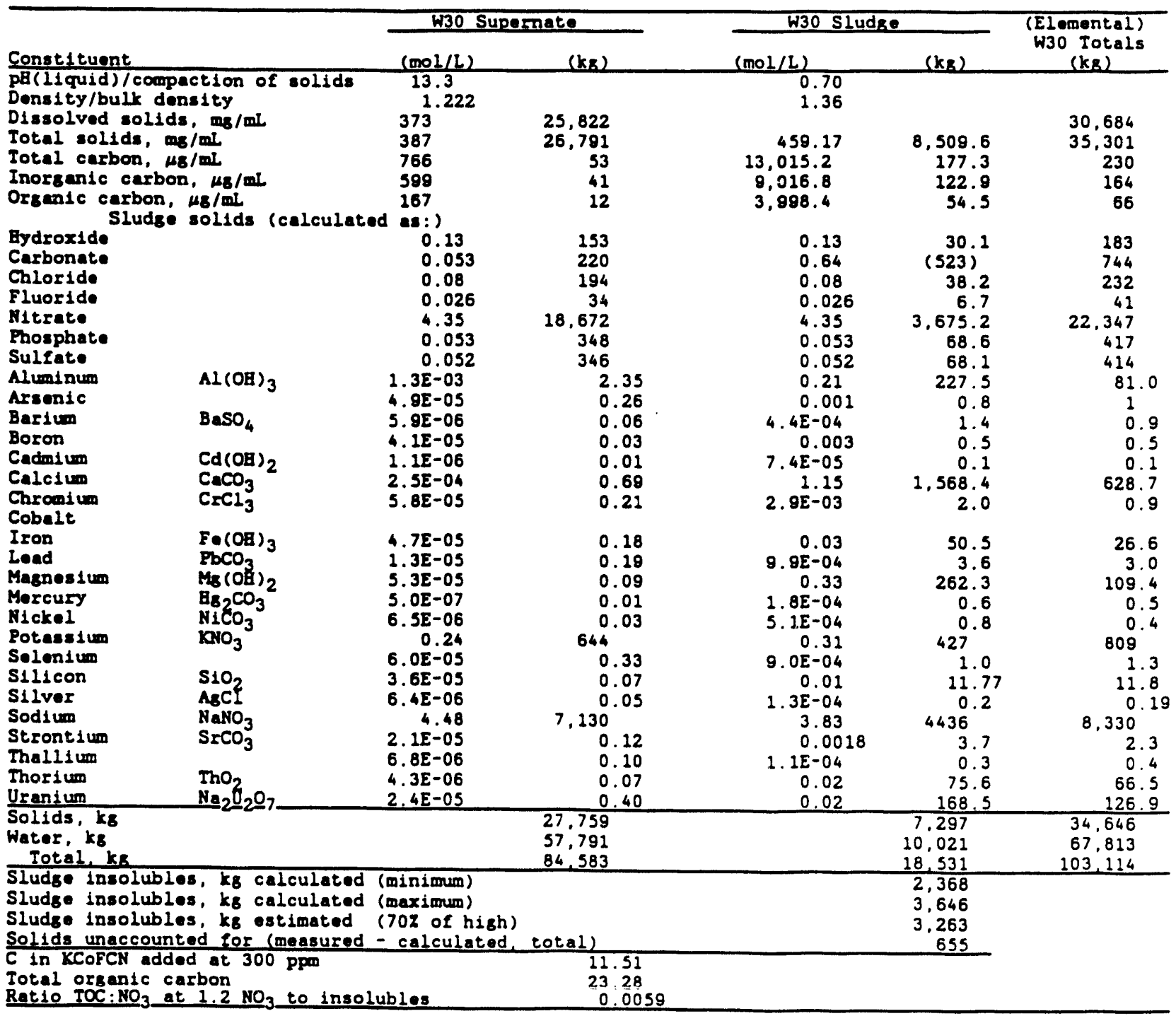


Table A.10. Analytical and radiological data for LLLW tank W-31 A. Radiological Analyses

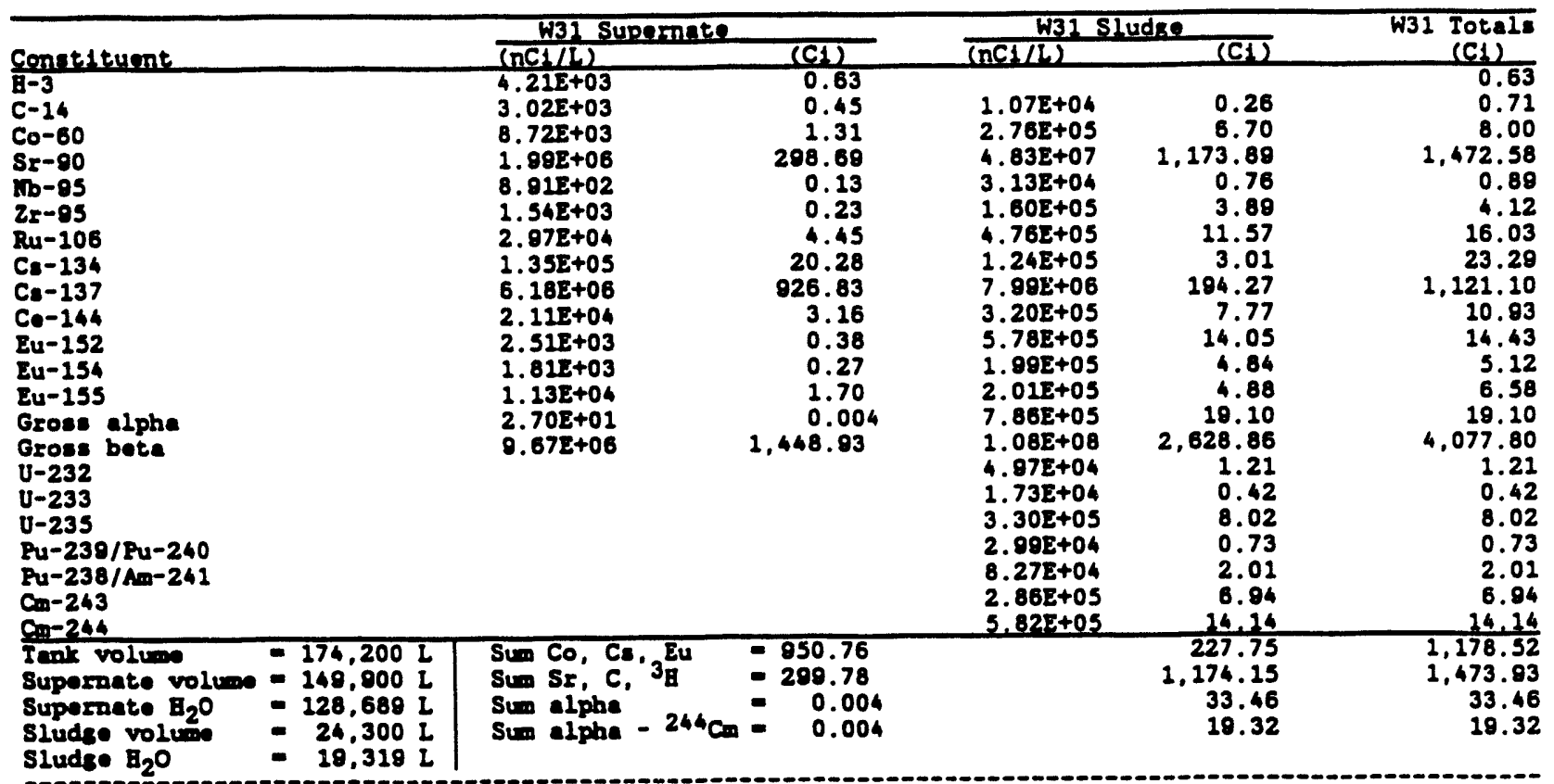

B. Pbyselcal/Chenical Analysos

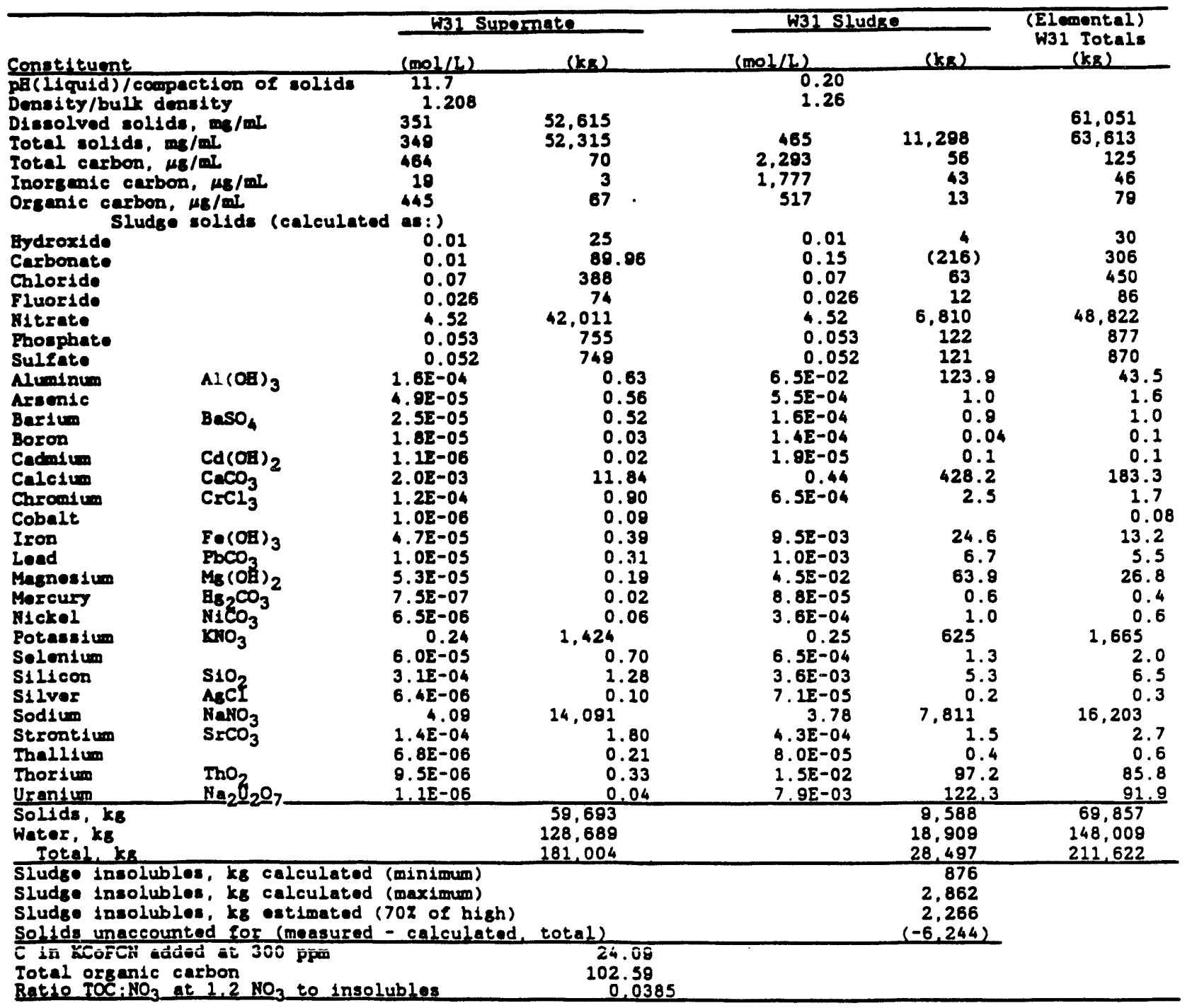


Table A.11. Summation of constituents in all LLLW tanks A. Radiological Analyses

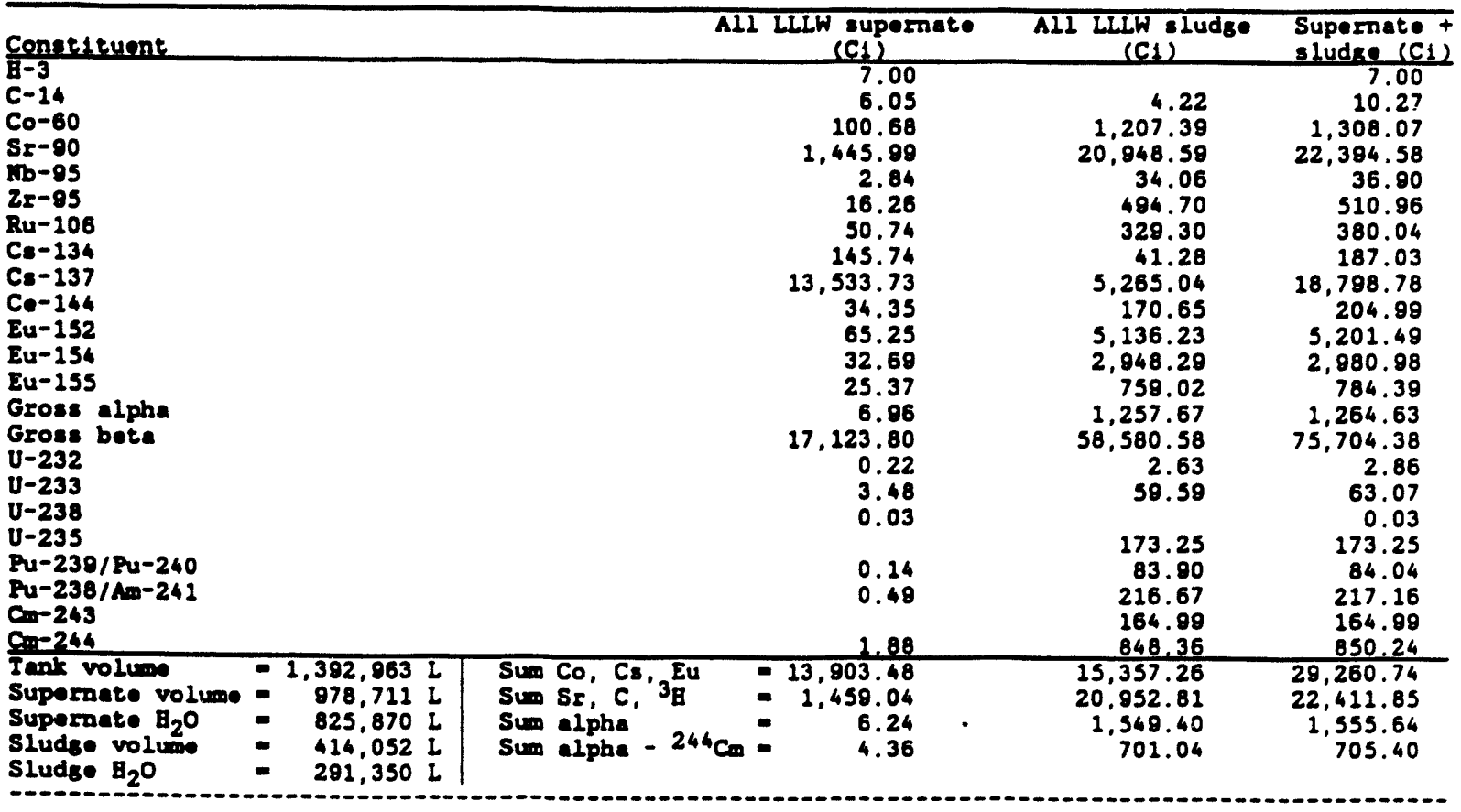

B. Physical/Chemical Analyses

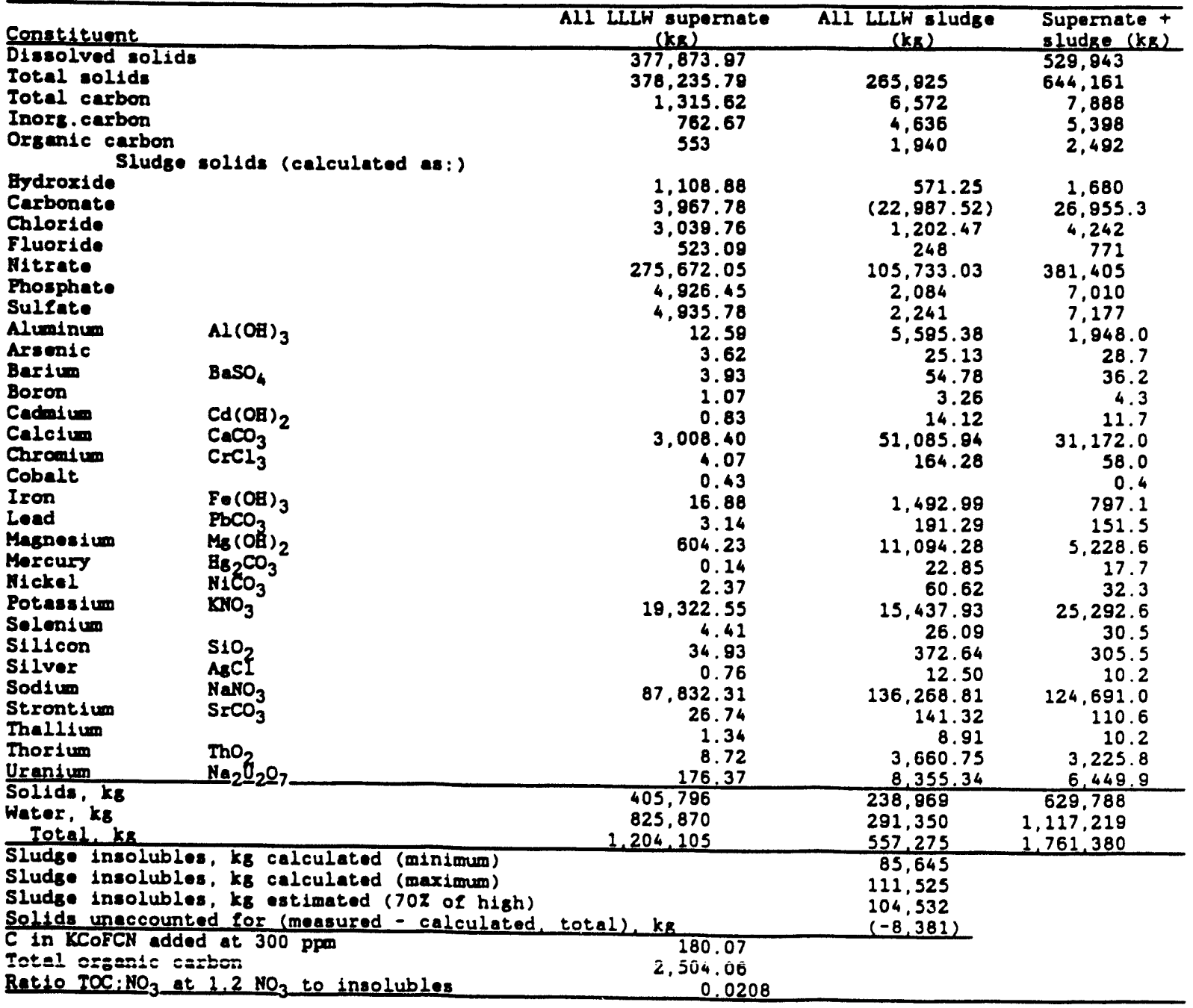


APPENDIX B. DEFINITIONS AND COMPUTATIONAL METHODS FOR LLLW TANK COMPOSITIONS 


\section{SUPERNATE}

1. The radioactive concentration of each supernate component was converted from $\mathrm{Bq} / \mathrm{mL}$ (Sears et al. ${ }^{1}$ ) to $\mathrm{nCi} / \mathrm{L}$ by multiplying by the factor $(27 \mathrm{nCi} / \mathrm{L} / \mathrm{Bq} / \mathrm{mL})$.

$2 . \mathrm{Ci} /$ tank $=$ component concentration $\times$ supernate volume.

3. Volume of material in each tank was given by Sears et al. ${ }^{1}$

4. Volume of sludge in each tank was given by Sears et al. ${ }^{1}$

5. Volume of liquid or supernate in each tank was the Total - Sludge.

6. Dissolved solids content $=$ dissolved solids, $\mathrm{mg} / \mathrm{mL} \times$ supernate volume.

7. Total solids content $=$ total solids, $\mathrm{mg} / \mathrm{mL} \times$ supernate volume.

8. Total carbon content $=$ total carbon, $\mu \mathrm{g} / \mathrm{mL} \times$ supernate volume.

9. Organic carbon content $=$ organic carbon, $\mu \mathrm{g} / \mathrm{mL} \times$ supernate volume. (Direct measurement for sludge, and total - inorganic for supernate.)

10. Inorganic carbon content = total carbon - organic carbon for sludge, and direct measurement for supernate.

11. Elemental and inorganic compound concentrations were given by Sears et al. ${ }^{1}$

12. Total elemental and inorganic compound contents were computed from the molar concentrations $\times$ molecular weight $\times$ supernate volume.

13. Supernate solids total $=$ elemental + inorganic compounds content.

14. Supernate total mass is the volume of supernate $x$ specific gravity.

15. Supernate water is the total mass - solids mass.

16. Gross alpha is measured gross alpha, $\mathrm{nCi} / \mathrm{L}$.

17. Gross beta is measured gross beta, $\mathrm{nCi} / \mathrm{L}$

18. Total uranium and total thorium are in $\mu \mathrm{g} / \mathrm{mL}$ based on chemical analyses.

19. The breakdown for TRU components $\left({ }^{222} \mathrm{U},{ }^{233} \mathrm{U},{ }^{299240} \mathrm{Pu},{ }^{238} \mathrm{Pu} /{ }^{41} \mathrm{Am}\right.$, and $\left.{ }^{244} \mathrm{Cu}\right)$ was provided for a few tanks.

20. If an analysis gave a "less than" concentration (e.g., $<0.01 \mathrm{mg} / \mathrm{L}$ for $\mathrm{Co}, \mathrm{As}, \mathrm{B}, \mathrm{Ag}, \mathrm{Fe}$, $\mathrm{Cr}, \mathrm{Se}, \mathrm{Si}, \mathrm{Tl}$, and sometimes $\mathrm{Mg}, \mathrm{Ni}, \mathrm{U}, \mathrm{Al}, \mathrm{CO}_{3}$ and $\mathrm{OH}$ ), that number (e.g., 0.01 for $<0.01$ ) was used to compute the content of that component, giving a maximum amount for the tank. 


\section{SLUDGE}

1. Bulk density is the density of the fully mixed sludge.

2. Analytical total solids, $\mathrm{mg} / \mathrm{mL}$, are the measured solids from evaporation of the sample x sample density.

3. Compact solids were obtained by centrifugation of a given volume and comparison of the settled volume to the total. ${ }^{2}$

4. Total carbon, organic carbon, and inorganic carbon were as described above.

5. Gross alpha and gross beta were as described above for supernate.

6. Hydroxide, mol/L, is the supernate value; and the quantity is based on hydroxide from $\mathrm{Mg}, \mathrm{Fe}$, and $\mathrm{Al}$ hydroxides plus the hydroxide in interstitial supernate.

7. Chloride, mol/L, is the supernate value; and the quantity is based on chloride from chromium and silver chlorides plus the chloride in the interstitial supernate.

8. Nitrate, mol/L, is the supernate value; and the quantity is based on nitrate from sodium and potassium nitrates.

9. Sodium, mol/L, is analytical data; and the quantity is based on sodium nitrate.

10. Potassium, mol/L, is analytical data; and the quantity is based on potassium nitrate.

11. Carbonate, mol/L, is calculated from the inorganic carbon value; and the quantity in parentheses is calculated from the mol value.

12. Calcium, lead, mercury, nickel, and strontium, mol/L, are the analytical data; and the quantities are based on the insoluble carbonates.

13. Magnesium, aluminum, cadmium, and iron, mol/L, are analytical data; and the quantities are based on insoluble hydroxides.

14. Uranium, mol/L, is analytical uranium data; and the quantity is based on $\mathrm{Na}_{2} \mathrm{U}_{2} \mathrm{O}_{7}$.

15. Thorium, mol/L, is analytical thorium data; and the quantity is based on thorium oxide.

16. Barium, mol/L, is analytical barium data; and the quantity is based on barium sulfate.

17. Chromium, mol/L, is analytical chromium data; and the quantity is based on chromium trichloride.

18. Silver, mol/L, is analytical silver data; and the quantity is based on silver chloride. 
SLUDGE (continued)

19. The sludge analyses for W-29 and W-30 were taken from the report by Peretz et al. ${ }^{3}$

20. The total mass of the sludge is the sludge volume multiplied by the sludge density.

21. The total mass of solids in the sludge is found by multiplying the analytical total solids by the volume of sludge.

22. The total solids in sludge are the sum of the masses of solid compounds calculated above, excluding nitrate, chloride, hydroxide, and carbonate masses; total carbon is included.

23. The total water in the sludge is the total sludge mass minus analytical total solids.

24. Soluble solids in the sludge are the sum of the sodium and the potassium nitrates.

25. Insolubles are the solid compounds added together, minus the sodium and potassium nitrates. This quantity also represents the minimum insoluble solids in the sludge.

26. The maximum insoluble solids are found by subtracting the soluble solids from the analytical solids.

27. The estimated insoluble solids in the sludge are found by taking $70 \%$ of the difference between the maximum and minimum insolubles (above) and adding the minimum insolubles. 


\section{SUPERNATE PLUS SLUDGE TOTALS}

1. Carbon, hydroxide, and chloride are supernate-plus-sludge totals.

2. Sodium is the supernate sodium plus the sodium in the sodium nitrate in the sludge.

3. Potassium is the supernate potassium plus the potassium fraction of the potassium nitrate in the sludge.

4. Carbonate is the supernate carbonate plus the carbonate, based on the analytical estimate for the sludge (the value in parentheses).

5. Calcium, lead, mercury, nickel, and strontium are the supernate quantities plus the cation fractions of the carbonate compounds in the sludge.

6. Silicon is the supernate silicon plus the sludge silicon.

7. Magnesium, cadmium, aluminum, and iron are supernate quantities plus the cation fraction of the compound hydroxides in the sludge.

8. Uranium is the uranium in the supernate plus the uranium fraction of the sodium diuranate in the sludge.

9. Barium is the supernate barium plus the barium fraction of the barium sulfate in the sludge.

10. Thorium is the supernate thorium plus the thorium oxide in the sludge.

11. Chromium is the supernate chromium plus the chromium fraction of the chromium trichloride in the sludge.

12. Silver is the supernate silver plus the silver fraction of the silver chloride.

13. Solids unaccounted for are the measured total solids minus the calculated solids.

14. The ratio of TOC: $\mathrm{NO}_{3}$ at $1.2 \mathrm{NO}_{3}$ to insolubles is the total organic carbon from the supernate and sludge plus the carbon in the $\mathrm{FCN}$ required to remove the ${ }^{137} \mathrm{Cs}$ from both the supernate and interstitial supernate in the sludge at $300 \mathrm{ppm} F C N$, divided by the nitrate equal to 1.2 times the estimated insolubles in the sludge.

15. The cation totals for both supernate and sludge are determined from selenium, thallium, boron, and arsenic. 
ORNL/TM-11799

\section{INTERNAL DISTRIBUTION}

1. H. L. Adair

2. J. M. Begovich

3. J. T. Bell

4. J. B. Berry

5. W. D. Bond

6. C. H. Brown, Jr.

7. D. O. Campbell

8. R. M. Canon

9. E. D. Collins

10. K W. Cook

11. A G. Croff

12. T. A Dillow

13. S. M. DePaoli

14. C. P. East

15. W. Fulkerson

16. R. K. Genung

17. J. R. Hightower

18. L Holder

19. E. K Johnson

20. C. M. Kendrick

21. T. E. Kent

22. K. H. King-Jones

23. J. R. Lawson
24-25. D. D. Lee

26. J. J. Maddox

27. R. C. Mason

28. A. J. Mattus

29. L. E. McNeese

30. L J. Mezga

31. J. J. Perona

32. D. J. Peterson

33. D. J. Pruett

34. S. M. Robinson

35. T. F. Scanlan

36. C. B. Scott

37. M. G. Stewart

38. P. A. Taylor

39. J. R. Trabalka

40. D. W. Turner

41. E. L. Youngblood

42. Cen. Res. Library

43. Doc. Ref. Section

44. Lab Records

45. Lab Records, R.C.

46. ORNL Pat. Sect.

\section{EXTERNAL DISTRIBUTION}

47. Office of Assistant Manager, Energy Research and Development, DOE-OR, P. O. Box 2001, Oak Ridge, TN 37831-8600

48-57. Office of Scientific and Technical Information, P. O. Box 62, Oak Ridge, TN 37831 

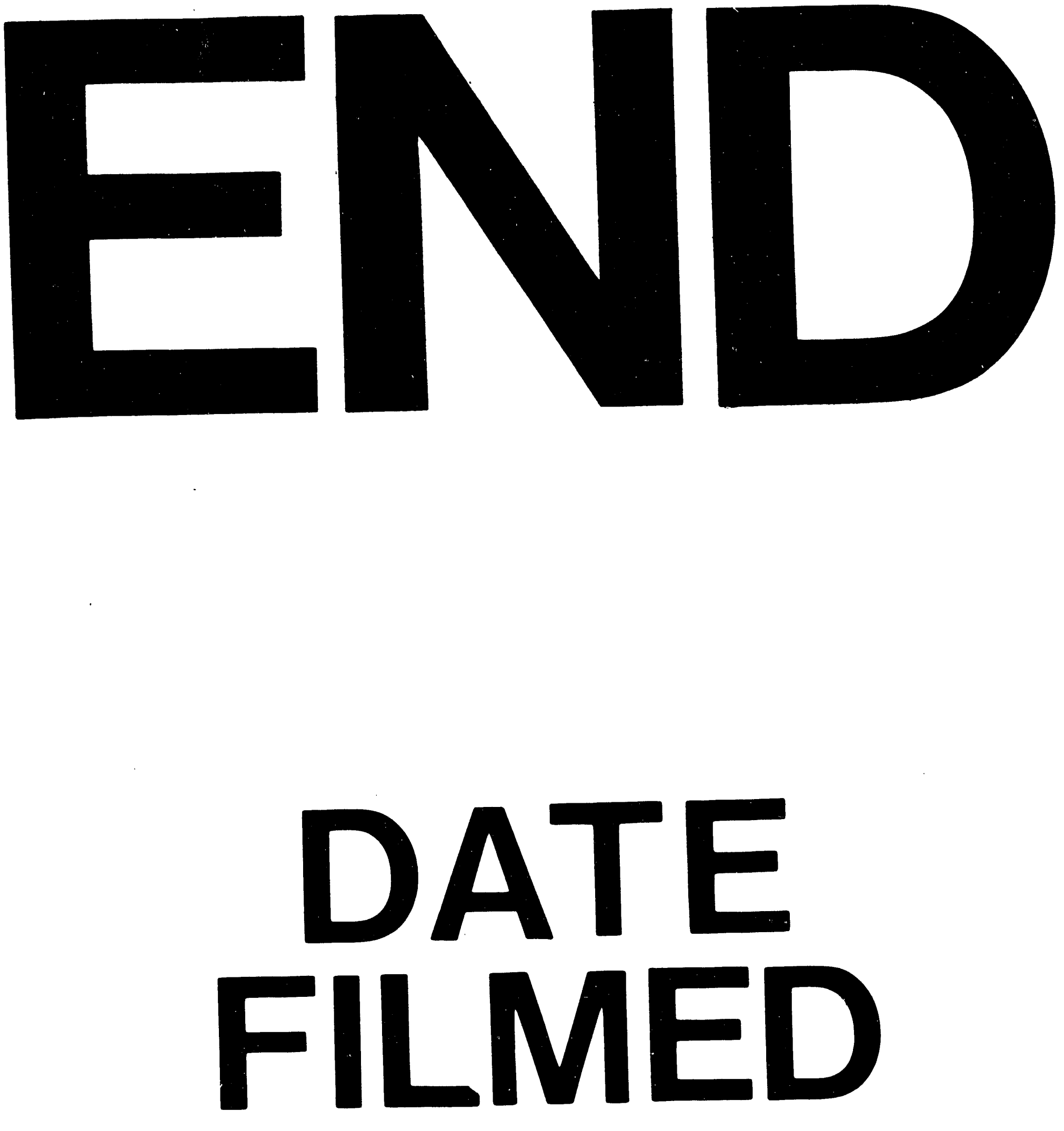

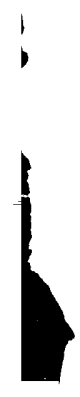

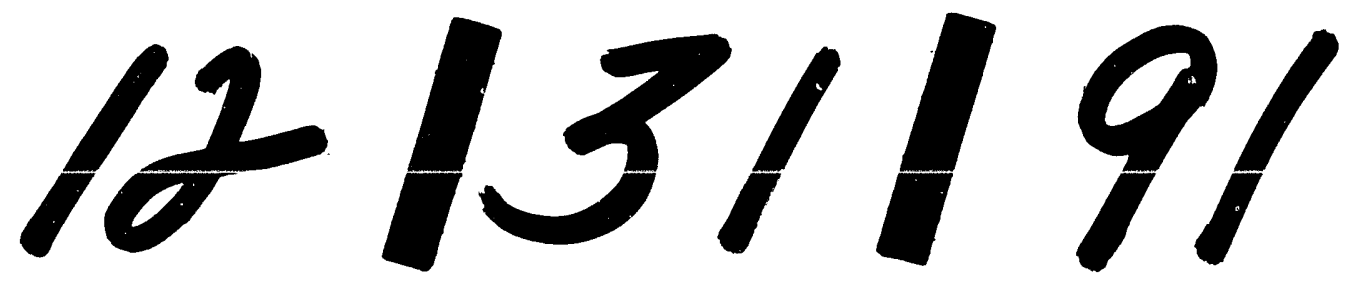


. 